\title{
The Northern Samail Ophiolite: An Oxygen Isotope, Microprobe, and Field Study
}

\author{
DEBRA S. STAKES \\ Department of Geology, University of South Carolina, Columbia \\ Hugh P. TAYLOR, JR \\ Divition of Geological and Planetay Sciences, Califormia Intrimute of Technology, Pasadena
}

\begin{abstract}
Geological, petrological, and oyggen isotopic data are presented for 228 whole rock and mineral samples collected from a $100 \times 20 \mathrm{~km}$ area of the northern Samail ophiolite in Oman. Most of these samples are from three detailed profiles through the pillow lavas, sheeted dikes, and layered gabbros of this laterally heterogeneous fragment of Cretaceous oceanic crust, down to and across the petrologic Moho. The profiles encompass a range of petrologic and tectonic styjes, and each profile exhibits distinctive ${ }^{18} \mathrm{O} /{ }^{16} \mathrm{O}$ variations compared to one another and to mid-ocean ridge basalts, as a result of pervasive seawater-hydrothermal interaction that varied in intensity along strike in the ophiolite. In general, ${ }^{18} \mathrm{O}$ depletions are observed in the layered gabbros and ${ }^{18} \mathrm{O}$ enrichments in most of the sheeted dikes and pillow lavas, similar to results previously observed in the southem part of the ophiolite (Ibra area), where ${ }^{18} 0$ depletions within the gabbroic section are quantitatively balanced by ${ }^{18} \mathrm{O}$ enrichments in the shallower parts of the oceanic crust. The Wadi Hilti profile, selected as an example of relatively intact crust, differs from Ibra in having more uniform and slightly higher $\delta^{18} \mathrm{O}$ in the gabbros $(+5.4$ to +6.3$)$, as well as in containing more hydrous alteration minerals (amphibole, epidote, chlorite, and prehnite). The profiles in the Wadi Kanut-Shafan and Wadi Rajmi sections are much more complex and reveal the impact of off-axis intrusions and deep crustal shearing. Plagiogranitewehrlite intrusions in the Shafan-Kanut area superimposed a local hydrothermal aureole on the ophiolite, evident in dikes highty depleted in ${ }^{18} \mathrm{O}$, quartz-sulfide veins, abundant epidote, thullite, and chlorite in shallower rocks, and low-temperature hydrous alteration of deeper gabbroic rocks; the latter produced an overall increase in whole rock $\delta^{18} \mathrm{O}(+6.2$ to +6.9$)$. Such late stage intrusions are found throughout the northern half of the Samail ophiolite. The Wadi Rajmi area, which is a possible fossil transform or propagating rift, represents the most complex of the three profiles; it also contains the most abundant highly deformed and hydrothermally altered rocks, together with the deepest and largest zone of ${ }^{18} \mathrm{O}$ depletion yet found in any ophiolite (locally ${ }^{18} \mathrm{O}<+2.0$ ). Conduits for lange volumes of high-temperature hydrothermal fluids were provided by fractures now occupied by $10 w-{ }^{18} \mathrm{O}$ gabbro pegmatites and $10 \mathrm{w}-{ }^{18} \mathrm{O}$ dikes. Material balance estimates for the regional samples and from the various transects through the ophiolite give crustal bulk $\delta^{18} \mathrm{O}$ averages $(+5.9$ to +6.3$)$ that are, within sampling error, almost identical to the average MORB basalt value of about +5.8 , if both vertical and lateral crustal heterogeneities are integrated into a threedimensional model. This supports and amplifies the conclusion of earlier workers that the $\delta{ }^{18} \mathrm{O}$ of seawater is buffered and controlled by hydrothermal interaction with oceanic crust, as long as the cumulative effects (both spatial and temporal) of all seafloor magmatic/hydrothermal processes are considered. The very slight out-of-balance enrichment of the integrated crustal average $\delta^{18} \mathrm{O}$ compared to MORB may be explained by the ubiquitous mineralogical and isotopic evidence for a late, low-temperature alteration event in the basal gabbros; these effects are prominent in the vicinity of the petrologic Moho and may indicate exchange with low-temperature aqueous fluids during or after detachment of the obducted slab.
\end{abstract}

\section{INTRODUCTION}

This is the first of a series of studies by us on the axygen isotope and mineralogical relationships in the northern half of the Samail ophiolite, arguably the largest, best exposed, and most complete mass of oceanic lithosphere amenable to geologic study anywhere on Earth [e.g., Glennie et al, 1974; Hopson et al, 1981]. Field studies and sample traverses were undertaken beginning in 1981 and continuing in 1983 and 1985 in order to obtain an appropriate suite of rocks that would allow us to determine the isotopic variability within a number of $\delta^{18} \mathrm{O}$ versus depth profiles along the strike of this large fragment of oceanic crust. Laboratory studies of these samples were later made at both California Institute of Technology (Caltech) and at the University of South Carolina. These studies complement and extend the studies in the southern part of this ophiolite by Gregory and Taylor [1981],

Copyright 1992 by the American Geophysical Union.

Paper number 91JB02743.

$0148-0227 / 92 / 91 \mathrm{JB}-02743 \$ 05.00$ who were the first to show that an entire oceanic crustal section of an ophiolite was isotopically modified by pervasive and ubiquitous hydrothermal interactions with ocean water, locally extending down to or even beneath the Moho.

These kinds of axygen isotope studies give us detailed insight into the deeper workings of mid-ocean ridge hydrothermal systems, thereby increasing our understanding of how such systems affect the global beat balance and the geochemistry of seawater. Although there is evidence that many ophiolites may have formed in settings other than a mid-ocean ridge [Cameron, 1985; Coish et al., 1983; Coish and Church, 1979; Hawkins et al., 1984], there is no question that these bodies all represent some type of oceanic crust formed in an extensional environment (e.g., marginal basin crust formed by back arc spreading). Thus, the study of ophiolites is still essential in understanding the construction and hydrothermal cooling of oceanic crust. In particular, the Samail ophiolite has been characterized by several workers as being true oceanic crust formed in the Tethyan Sea at a fast or intermediate spreading rate just northeast of the present-day northern coast of Oman [Nicolas et al., 1988a,b; Pallister and Hopson, 1981; Hopson et al., 
1981; Coleman, 1981]. A crustal thickness of 5-7 km of gabbroic and basaltic rocks and a remarkable continuity of the pillow lavas, sheeted dikes, and plutonic sequences make it the best ophiolite analogue to the seismic structure of normal oceanic lithosphere.

The Samail ophiolite complex was formed during the Upper Cretaceous (Cenomanian to Turonian/Coniacian [Glennie et al., 1974]), probably over a very narrow time interval ( $-94-97 \mathrm{Ma}$ [Tilton et al., 1981]). Shortly thereafter, the body was obducted onto continental crust [Ghent and Stout, 1981; Lanphere, 1981]. Emplacement of the ophiolite resulted in structurally intact blocks in which the stratigraphy is largely undisturbed [Smewing, 1980; Smewing et al., 1984]. Along strike there are over $600 \mathrm{~km}$ of continuous exposure, and locally one can walk downward into the upper mantle to a depth of 10-15 km beneath the Moho. Magmatic and metamorphic processes can be studied on a local, outcrop by outcrop scale, and these local studies can be compared along the entire strike length of the body. This is important because the major tectonic features of the oceanic crust are very large and likely to be absent or poorly discernible in a small ophiolite fragment (Figure 1).

The Oman ophiolite and the present-day East Pacific Rise are compared at the same scale in Figure 1, modified after Nicolas et al. [1988a]. Such fast spreading ridges typically display a periodic segmentation, with the segments being separated from one another by a variety of structural and magmatic discontinuities, including faults, overlapping spreading centers, and small nonoverlapping offsets [Batiza and Margolis, 1986; Macdonald et al.,

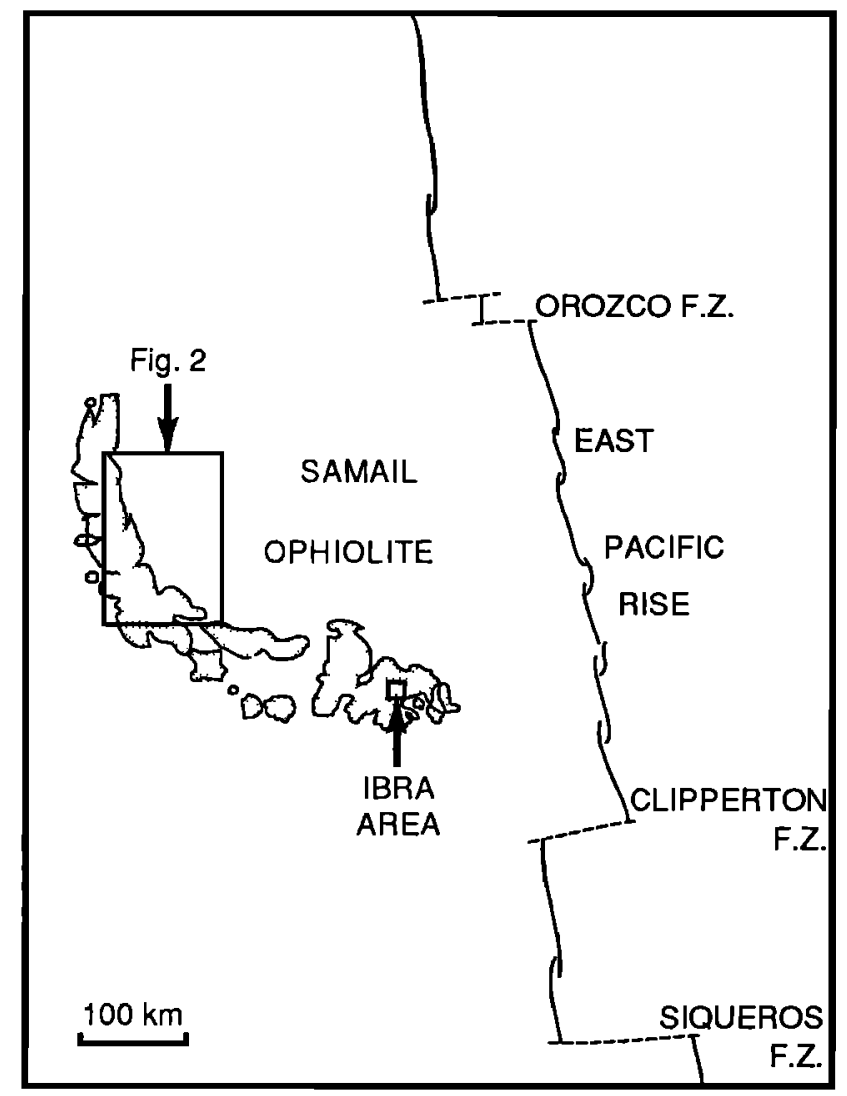

Fig. 1. Comparison of the outcrop area of the Samail Ophiolite with a portion of the East Pacific Rise, at the same scale (modified after a similar diagram of Nicoles et al. [1988a]). Also shown are the locations of Figure 2 and of the Ibra area studied by Gregory and Taylor [1981] and Pallister and Hopson [1981].
1984; Sempere and Macdonald, 1986; Macdonald et al., 1988; Cooper et al, 1987].

The most important influences on hydrothermal convective systems in nature are heat and permeability [e.g., Norton and Taylor, 1979]. Virtually all oceanic hot springs occur along fissures and faults [Karson and Rona, 1990; Tivey et al., 1989], and studies of ophiolites confirm that hydrothermal discharge is dominated by fractures [Schiffman and Smith, 1988; Varga and Moores, 1985; Harper et al., 1988]. Fissures and faults are probably major contributors to the permeability of oceanic crust at mid-ocean ridges, and they probably play a fundamental role in off-axis magmatic activity as well [Stakes et al., 1984a; Cannat et al., 1991]. The depth and orientation of such faults within the crust are information not easily obtained from seafloor studies, but these features are readily mapped in a well-exposed ophiolite [Reuber, 1988; Juteau et al., 1988a, b]. Anticipating the discussion below, we note that Reuber [1988] and Smewing [1981] have suggested that one of the transects we have studied in detail in this work (Wadi Rajmi) is either a highly sheared and fractured overlapping spreading center (OSC) or a fossil transform, respectively.

\section{Previous Geological Studies

OF THE SAMAIL OPHIOLITE

Structural and petrogenetic studies of the Samail ophiolite by several independent groups have resulted in detailed descriptions of the main ophiolite lithostratigraphy, although there is as yet no clear consensus with regard to the mode of its construction or its tectonic setting. Regional mapping of a $30-\mathrm{km}$ strip in the SE Oman Mountains by an American group [e.g., Coleman and Hopson, 1981] indicated these fundamental units of the ophiolite (from bottom to top): (1) tectonized peridotite; (2) petrologic Moho; (3) layered gabbro (3-5 km thick); (4) a thin (<1 km thick) unit of amphibole-bearing noncumulus gabbro; (5) sheeted diabase dike complex (1.0-1.8 km thick); and (6) pillowed basaltic flows ( $<1 \mathrm{~km}$ thick). The ophiolite was interpreted by this group to represent normal Tethyan oceanic crust formed by crystallization on the floor, roof, and walls of a large (15 km half width) basaltic (mid-ocean ridge basalt) magma chamber. The high-level gabbro and plagiogranite were thought to represent late differentiated magma frozen to the roof. The presence of olivine gabbro and wehrlite at high levels within the cumulate section was taken to indicate crystallization from new inputs of primitive magma.

Mapping in the northern Samail ophiolite (Figure 2) by a British group [e.g., Smewing, 1981; Lippard et al., 1986] was also interpreted as indicating formation at a fast spreading center but perhaps in a back arc, suprasubduction zone environment rather than at a mid-ocean ridge. The average cumulate section in the north is thinner $(3.5 \mathrm{~km})$ than in the south and contains thicker units of cumulate peridotite and intrusive peridotite (dunite and wehrlite). These interlayered mafic and ultramafic sequences were interpreted as the magmatic cycles of mantle input and crystal fractionation within a single large magma chamber [Smewing, 1981; Browning, 1984].

Detailed studies of the pillow lavas in the northern ophiolite by Alabaster et al. [1982] revealed three distinct units (in ascending stratigraphic order: Geotimes, Lasail, and Alley). The Geotimes lavas are widespread and typically aphyric, with green chloritic rims on large brown pillows [Alabaster, 1982; Smewing, 1990]. The Lasail and Alley units are related to distinct eruptive centers and show well-developed fractionation series from picrite basalt (only in the Alley lavas) and basalt to andesite, rhyolite, and obsidian. The Lasail and Geotimes units are hydrothermally 


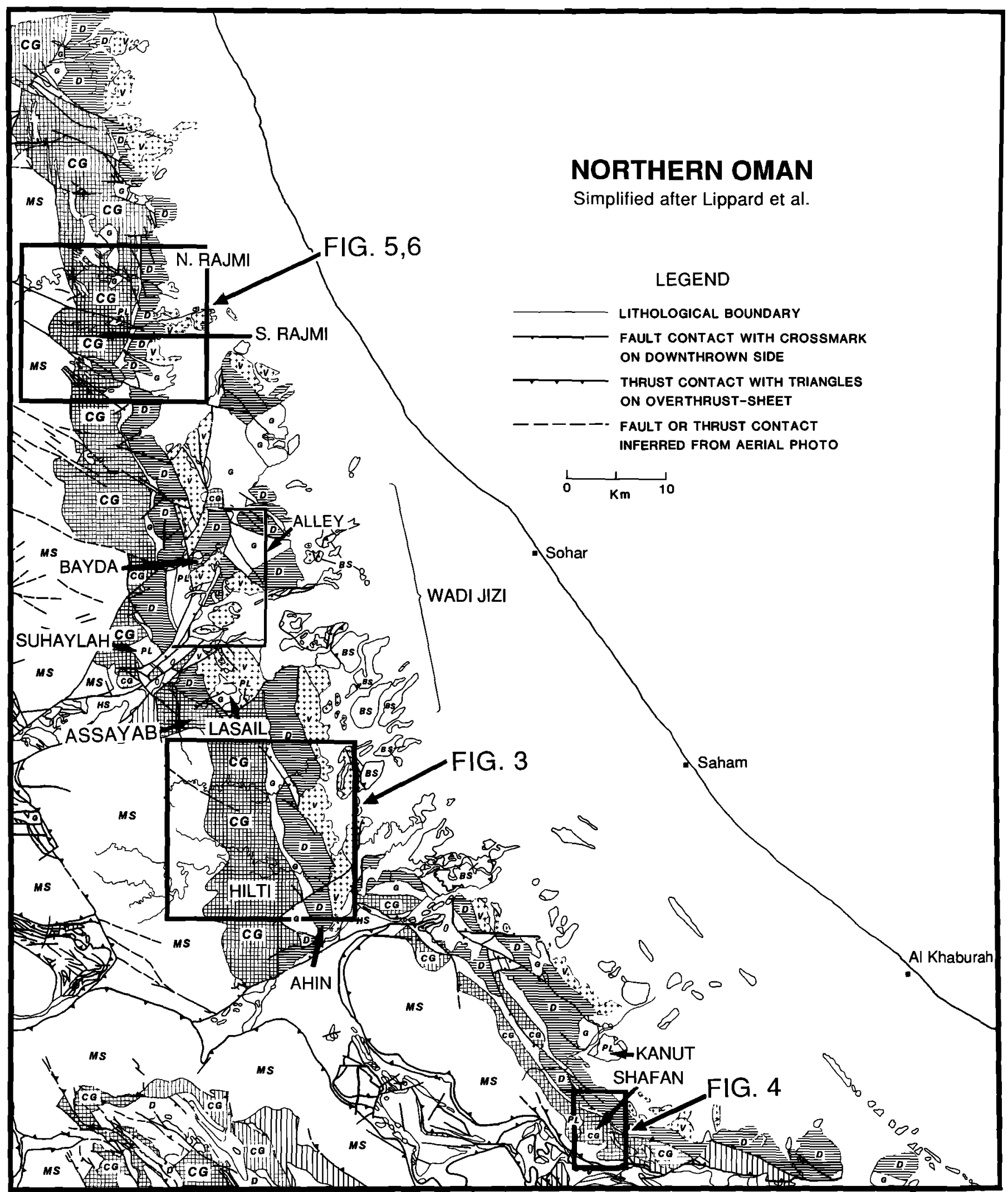

Fig. 2. Simplified geologic map of the northern part of the Samail Ophiolite, showing the areas sampled in the present work (geology modified after Smewing [1981] and Lippard et al. [1986]). The locations of Figures 3, 4, 5, and 6 are indicated. The explanations of the lithologic symbols are the same as those listed in Figure 3, except that $G$ is high level gabbro, $V$ is pillow lavas, and BS is basal allochthonous complex of Hawasina thrust sheets. 
TABLE 1. Oxygen Isotopic and Petrographic Data for Samples Collected From Map Localities 1-35 Along the Two Wadi Rajmi Profiles as Shown in Figures 5 and 6

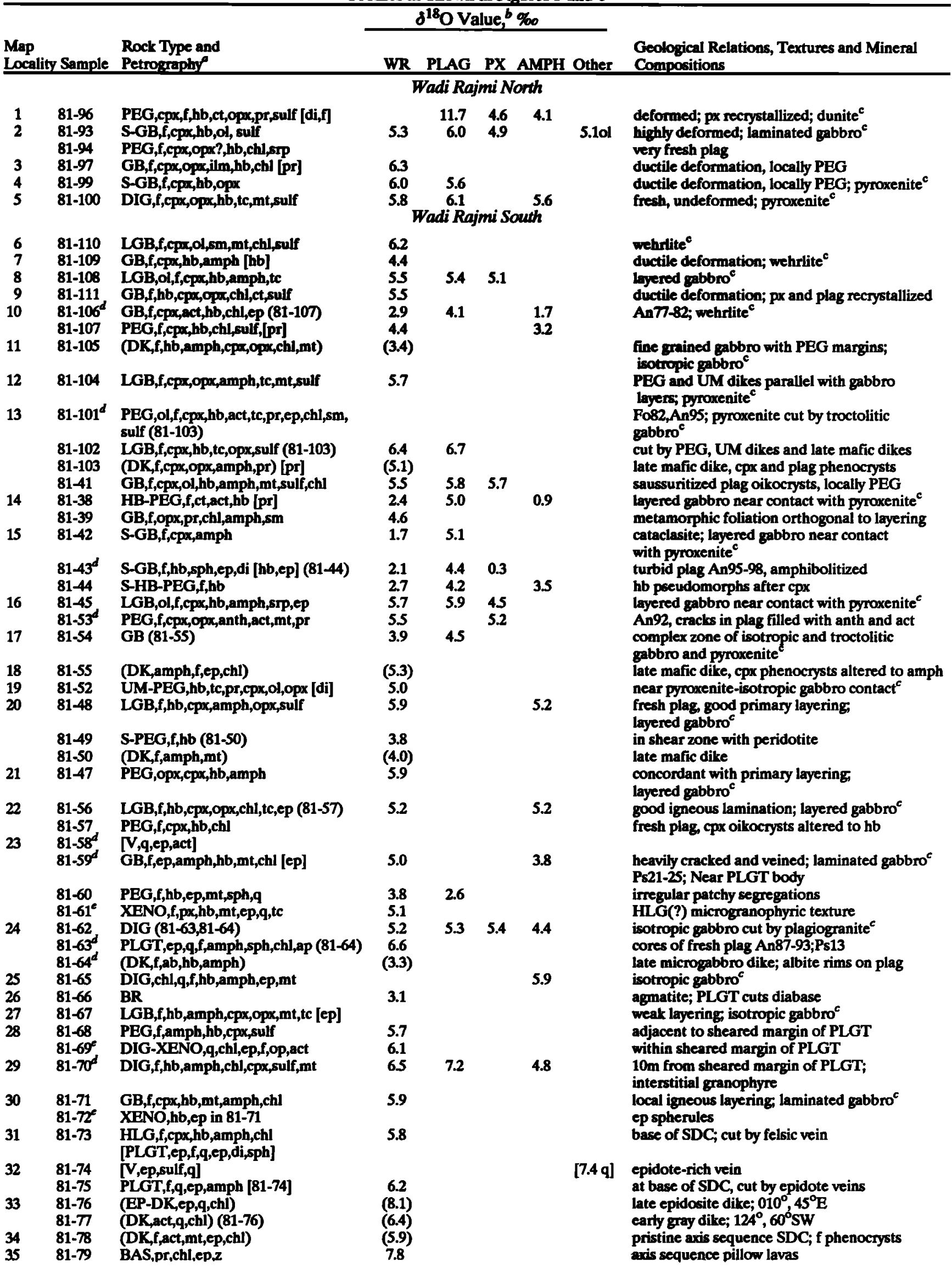


TABLE 1. (Continued)

\begin{abstract}
${ }^{a}$ GB, cumulate gabbro; DK, dike; PEG, gabbroic pegmatite; PLGT, plagiogranite; BR, breccia; BAS, pillow basalt; V, vein; XENO, xenolith; HLG, high-level isotropic gabbro at base of SDC; LGB, conspicuously layered cumulate gabbro; SDC, sheeted dike complex; UM, ultramafic rock, dominantly px + ol; DIG, deep isotropic gabbro. HB, bornblende; S, sheared, stronghy foliated, or plastically deformed rock collected from a well-defined shear zone; EP, strongly epidotized, e.g. epidosite. Either $f$ or plag, plagioclase (An is anorthite content); opx, orthopyroxene; cpx, clinopyroxene; px, pyroxene; ol, olivine; pr, prehnite; chl, chlorite; sm, smectite; sph, sphene; di, diopside; ct, cummingtonite; anth, anthophyllite; act, actinolite; hb, homblende; act-hb, actinolitic homblende; amph, green amphibole (fibrous or acicular); trem, tremolite; sulf, sulfides (pyrite, chalcopyrite, pyrrhotite, sphalerite); stp, serpentine; ep, epidote (Ps is pistacite content, Fe/Fe + Al); tc - talc; mt, magnetite; q, quartz; ab, albite; ap, apatite; z, zeolite or analcime. Rock names and minerals enclosed in brackets, e.g., [V,q,ep,sulf], represent materials from crosscutting veins; if brackets contain a sample number, e.g., [81-74], it indicates that the rock at that locality is cut by the vein 81-74; if brackets contain a $\delta^{18} O$ value, e.g. [7.4], it indicates that the mineral or whole-rock $\delta^{18} \mathrm{O}$ analysis is from vein material. Rock names and minerals enclosed in parentheses, e.g., (DK,f,amph,mt), represent a cross-eutting dike; if the parentheses contain a sample number, e.g., (81-50), it indicates that the rock at that locality is cut by the intrusive body $81-50$, which is usually a dike, but also may be a plagiogranite or pegmatite body; if the parentheses contain a $\delta^{18} O$ value, it indicates a whole-rock isotopic analysis of the dike.

bWR, whole rock; PLAG, plagioclase; PX, clinopyroxene; AMPH, amphibole; Other, mineral indicated by abbreviation.

'Map units designated by Reuber [1988] (also see Figure 6). The Reuber map units represent a considerably more complex and more detailed subdivision of the cumulate grbbro unit shown in Figure 4; these designations apply only to that part of the oceanic crustal section that lies beneath the sheeted dike complex.

Samples for which electron microprobe compositional data were obtained.

'Xenoliths and xenolith isotopic analyses.
\end{abstract}

altered in the greenschist facies and the overlying Alley lavas in the zeolite facies [Alabaster, 1982; Smewing, 1990; Pftumio, 1988]. The Geotimes unit is considered to be transitional in composition between MORB and island arc basalt (IAB), a characteristic of modern back arc basin spreading centers such as the Mariana Trough and the older portions of the Lau Basin [Hawkins and Melchior, 1985]. The upper units are considered to have IAB affinities and are interpreted as the products of off-ridge incipient island-arc formation [Pearce et al., 1981].

Structural mapping by a French group began in 1978, focused on the mantle peridotite [e.g., Boudier and Coleman, 1981]. In 1983, a systematic remapping of the ophiolite was begun by the Bureau de Recherches GEologiques et Minières (BRGM, [e.g., Buerrier, 1990]). More recent work has produced detailed structural sections in the crustal sequence [e.g., Reuber, 1988; Nicolas et al., 1988a,b], including detailed mapping and geochemistry of the Salahi block [Pflumio, 1988; Emewein et al., 1988] and the Haylayn block [Juteau et al., 1988a,b]; the latter studies identified possible relicts of distal edges of magma chambers or propagating rifts (e.g., Wadi Haymiliyah, Wadi Rajmi). Pflumio [1988] and Emewein et al. [1988] infer the existence of three volcanic episodes (VI-V3), with V1 broadly equivalent to the Geotimes unit and V2 to the primitive Lasail or Alley lavas, using the Alabaster and Pearce terminology. The V3 magmas are alkalic basalt, similar to oceanic island basalts.

The large wehrlite bodies found in the cumulate section play a central role in the genetic model proposed by the French group; they suggest that many (if not all) of the wehrlite and picrite layers may be late sills or dikes that have been tectonically rotated into concordant positions within the cumulate section. Evidence of segmentation of the spreading axis also was documented [Juteau et al., 1988b; Reuber, 1988]. The resulting model summarized by Nicolas et al. [1988a,b] creates the layering of the plutonic section by magmatic flow of the gabbros induced by the plastic flow of the underlying mantle.

\section{FIELd SAMPLING, Petrography, AND CHEMICAL AND ISOTOPIC ANAL YSES}

The geological, petrological, and geochemical data obtained in this study are presented in Tables 1, 2,3, and 4. Sample descriptions are brief and make extensive use of abbreviations but give the detailed mineralogy of each sample and indicate whether it is from the layered sequence, a xenolith, or a crosscutting vein or dike. Samples were obtained from several localities within a $\mathbf{1 0 0}$ $\mathrm{km} \times 20 \mathrm{~km}$ area (Figure 2). Petrographic thin sections were examined from 179 samples collected from 137 localities. Mineral separates and whole rock powders were prepared from most of these samples, and 228 were analyzed for ${ }^{18} \mathrm{O} /{ }^{16} \mathrm{O}$. Electron microprobe determinations of compositions of 16 feldspars, 22 pyroxenes, 20 amphiboles, 10 epidotes, five chlorites, one serpentine, and five prehnites, from 17 representative samples are given in Tables 5-10. A few other microprobe analyses are briefty referred to in the text and in Tables 1-4.

The sample localities are plotted on detailed maps in Figures 3, 4 , and 5 , with the regional context given in Figure 2. The detailed site studies and maps are based on the regional map produced by The Open University (generalized in Figure 2), as this was all that was available in 1981 and 1983 when most of the field work was carried out. Recently, numerous detailed field mapping and petrographic studies in the northern Samail ophiolite have been published by a group of French workers [Boudier and Nicolas, 1988]. Mapping by Reuber [1988] is particularly relevant to our study and is reproduced here as our Figure 6; this map emphasizes the complex multigeneration intrusive structure discovered during the more recent work, as contrasted with the simple "layer cake" stratigraphy of the earlier studies. For comparison, in Table 1 the lithologic map units for our samples from Wadi Rajmi are also indicated utilizing the terminology of Reuber [1988].

Electron microprobe analyses were done at the California Institute of Technology (Caltech) on the MAC 5-SA3 probe, and at the University of South Carolina's (USC) Southeast Regional Microprobe Facility (Cameca SX-50), utilizing natural minerals as standards. A 7-10 $\mu \mathrm{m}$ beam was used on the more fragile hydrous samples and feldspar. At least five analyses were collected for each mineral and three to five individual crystals were analyzed to represent the average for the sample. For each sample, the zonation and maximum compositional variation in the mineral grains were noted. Secondary minerals were analyzed from selected samples to confirm optical identification. Mineral formulas are based on standard data reduction provided for each instrument (Tables 5-10) and include a plausible estimate of total iron as ferric and ferrous substitution [see Papike et al., 1974; and see Stakes et al., 1991]. For amphibole, the algorithms used to assign iron to the different oxidation states are based on certain crystallographic assumptions (see Table 7 and Robinson et al. [1982] and Vanko and Stakes [1991]). The recalculation produces four possible formulas: $\mathrm{FE}^{+2}$ is all $\mathrm{Fe}$ as ferrous $\mathrm{Fe}$; $15 \mathrm{NK}$ is total cations to 15 exclusive of $\mathrm{Na}$ and $\mathrm{K}, 15 \mathrm{~K}$ is total cations to 15 exclusive of $K ; 13 C N K$ is total cations total to 13 
excluding $\mathrm{Ca}, \mathrm{Na}$, and $\mathrm{K}$. For hornblendes coexisting with epidote, the 13CNK recalculation is usually most appropriate, while the $15 \mathrm{NK}$ is usually more appropriate for hornblende coexisting with cummingtonite and for $\mathrm{Fe}-\mathrm{Mg}$ amphiboles.

Oxygen was extracted from silicate samples using fluorine gas (at Caltech) or $\mathrm{ClF}_{3}$ (at USC) and converting the $\mathrm{O}_{2}$ to $\mathrm{CO}_{2}$ prior to isotopic analysis. Results are reported to a precision of 0.1 to $0.2 \%$ in the standard $\delta$ notation, relative to standard mean ocean water (SMOW). NBS-28 has a $\delta^{18} \mathrm{O}$ of +9.60 on this scale in our laboratories.

\section{Geology aNd Petrology of SELECTED \\ TRANSECTS IN THE NORTHERN SAMAIL OPHIOLITE}

\section{Features Common to Most of the Transects}

The sections of cumulate gabbro in the northern part of the ophiolite vary in thickness from 1 to $5 \mathrm{~km}$ and are composed of varying proportions of olivine, plagioclase, and clinopyroxene, with lesser quantities of orthopyroxene, spinel, and magnetite [e.g., Jutecu et al., 1988a,b; Smewing, 1981]. The lower cumulate gabbros are rhythmically phase-layered, and at the bottom of the sequence there may be a dunite-rich zone separating the crustal sequence from mantle peridotite (the petrologic Moho). Hydrous minerals are only rarely described in these lowermost cumulates of the southern Samail ophiolite, except as thin rims of red-brown hornblende on clinopyroxene [Pallister and Hopson, 1981; Gregory and Taylor, 1981] or talc-magnetite pseudomorphs after olivine. In contrast, the lower cumulates at most localities in the northern half of the Samail ophiolite commonly contain up to $5-10 \%$ primary and secondary amphibole, and even more in the vicinity of shear zones, as in the Wadi Rajmi area.

Near the top of the cumulate section, the layering commonly disappears and is replaced by a faint planar lamination of the cumulus minerals, for a stratigraphic thickness of up to a hundred meters. These planar-laminated gabbros also appear in some sections in the south where they are referred to as "transitional gabbros" by Pallister and Hopson [1981]. In the north, these laminated gabbros (see Figure 6) are most commonly gabbronorites [Juteau et al., 1988a]. Locally, this zone is invaded by a dense network of leuconorite and diorite impregnations that give way upward to a magmatic breccia.

The uppermost $500 \mathrm{~m}$ of gabbro are typically isotropic (no cumulate layering), with abundant amphiboles (Fe-actinolite to actinolite or magnesio-hornblende) and some epidote (locally thullite, as at West Shafan), chlorite, prehnite, and sphene. The texture is heterogenous, with medium- to fine-grained zones surrounded by hornblende-plagioclase pegmatite and cut by silicic pods and stringers of quartz and albite. The plagiogranite dikes or sills may intrude upward into the overtying dike complex. In the northern Samail ophiolite, isotropic gabbros are not confined to the top of the cumulate section, but also form as discrete bodies well down into the layered sequence [Reuber, 1988]; these are termed deep isotropic gabbro (DIG) in our terminology (Tables 1-4). Reuber [1988] believes that some of these occurrences represent "isotropization" of originally layered gabbro, evidenced by gradational transitions between the two facies in many localities.

The transition from layered or laminated gabbro to isotropic gabbro is usually abrupt, marked by the appearance of abundant amphibole and by blocks of gabbro broken up by more silicic magma (diorite to plagiogranite). The isotropic texture in some areas appears spotted, as pyroxene crystals are replaced by rounded clumps of amphibole. Phantom blocks of gabbro can be discerned within the high-level gabbros, where the core of the block is partially recrystallized to hornblende gabbro and the margins are pegmatites. In some areas, the high-level gabbros and plagiogranites intrude and partially assimilate or react with the base of the dike complex and so may represent the final magmatic event at the spreading axis. Here, xenoliths of diabase

TABLE 2. Oxygen Isotopic and Petrographic Data for Samples Collected From Map Localities 61-85 Along the Wadi Hilti Profile as Shown in Figure 3.

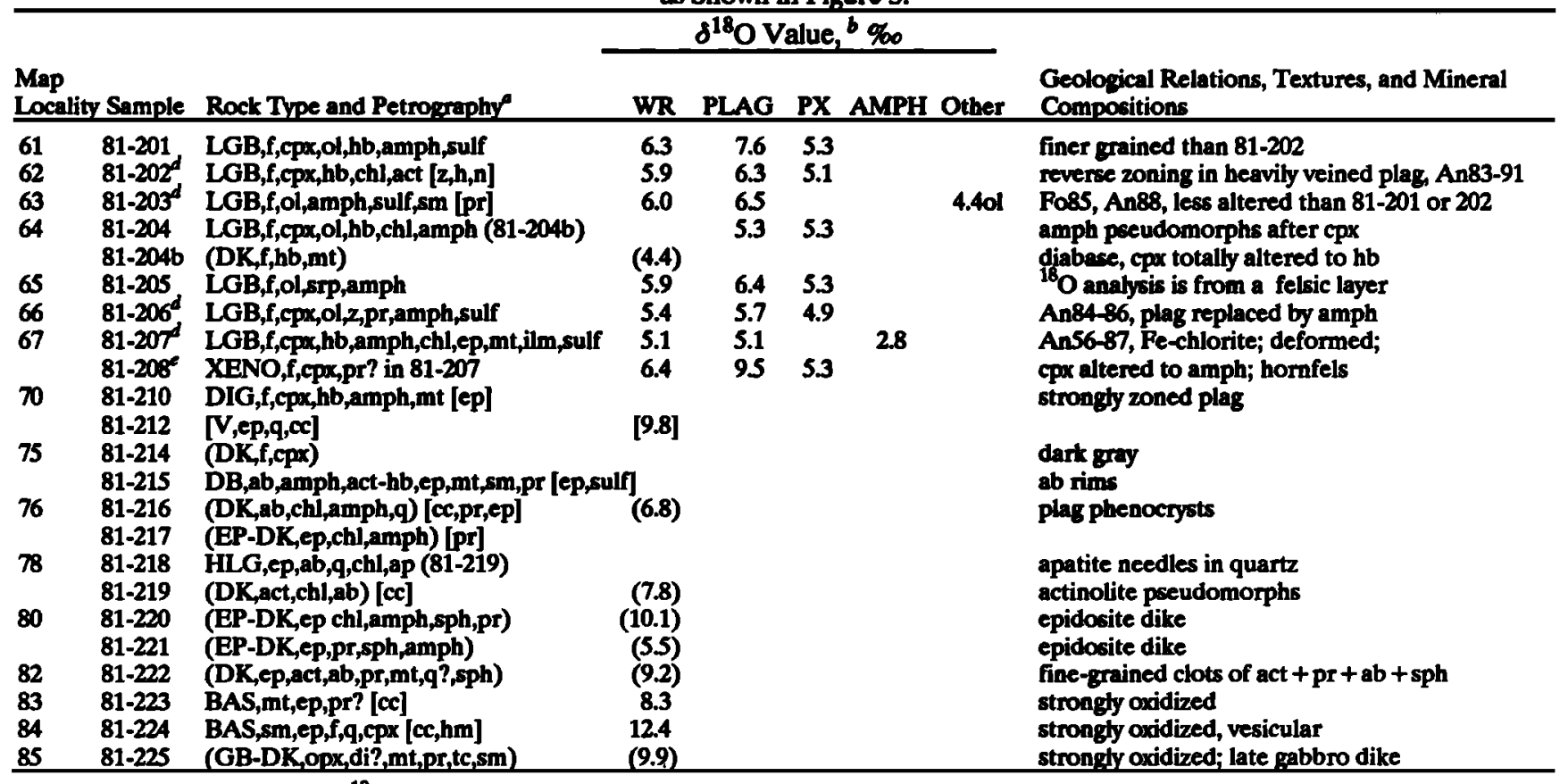

Notes and abbreviations for $\delta^{18} \mathrm{O}$ values, rock names, mineral names and prefixes are same as given for Wadi Rajmi in Table 1 , except that hm, hematite; cc, calcite 
TABLE 3. Oxygen Isotopic and Petrographic Data for Samples Collected from Map Localities 121-185 Along the Wadi Shafan Profile as Shown in Figure 4

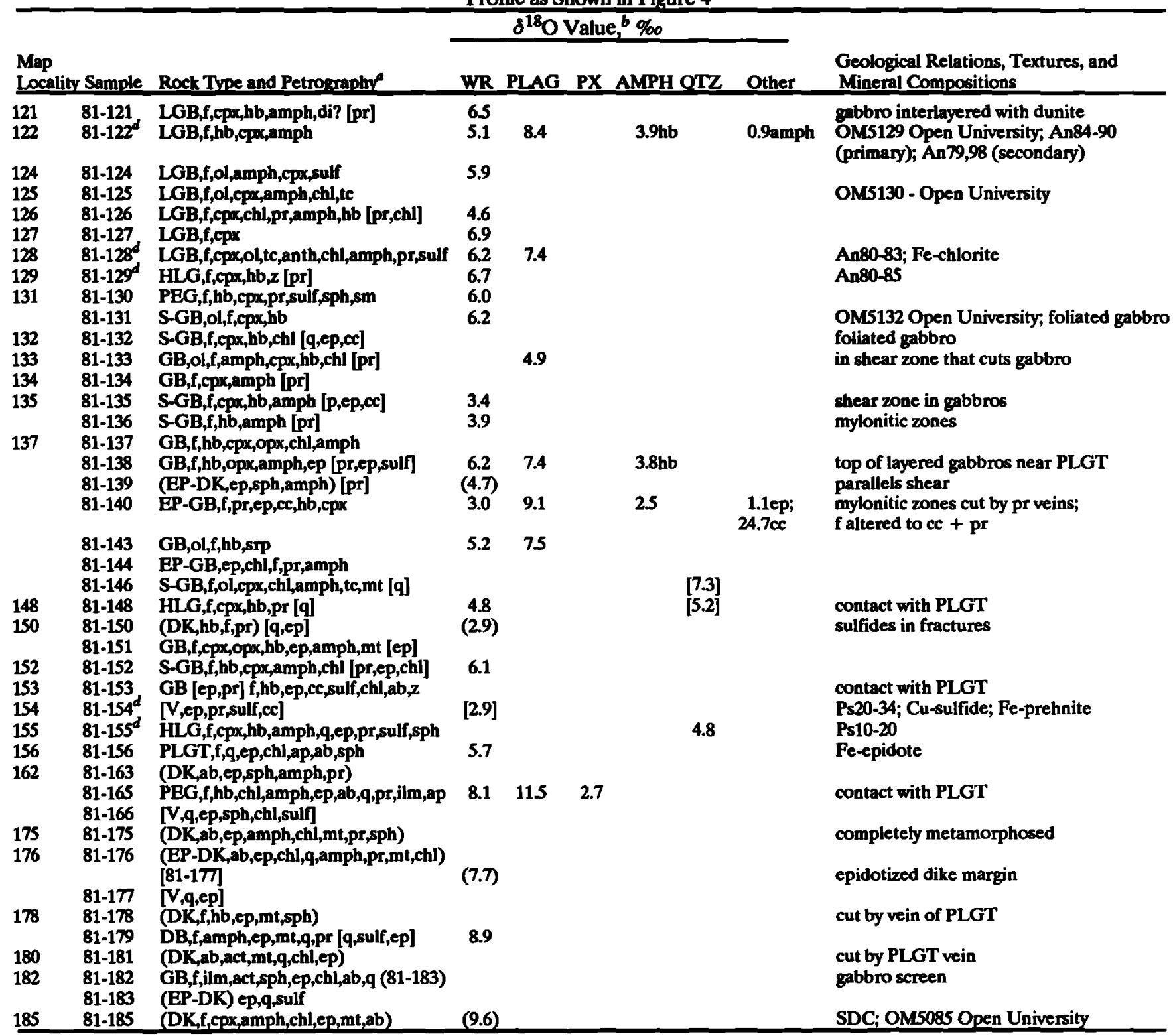

Notes and abbreviations for $\delta^{18} \mathrm{O}$ values, rock names, mineral names and prefixes are same as given for Wadi Rajmi in Table 1, except that zo, zoisite; ilm, ilmenite; $\propto$, calcite

from the dikes are evident in the plagiogranite and in the upper reaches of the high-level gabbro. Blocks of high-level gabbro surrounded by more felsic magma also suggest stoping. In other areas, a diking event postdates the high-level gabbro, which is evident as coarse-grained screens between the dikes. Less commonly, large plagiogranite bodies are crosscut by later mafic dikes. In the northern part of the ophiolite, most of the plagiogranites are associated with the off-axis intrusive complexes described below, but plagiogranites that form along the base of the sheeted dike swarm are likely related to the main stage of spreading.

The $1-2 \mathrm{~km}$ between the high-level gabbro and the pillow basalts are filled with vertical, subparallel sheets of diabase (Figure 2), the sheeted dike complex. These diabase dikes are pervasively altered to chlorite, albite, actinolite, sphene, quartz, and epidote [e.g., Hopson et al, 1981; Gregory and Taylor, 1981]. The uppermost gabbros and the lowermost dikes contain both chlorite and green amphibole, whereas epidote plus chlorite is more common in the dikes at shallower levels. In general, the sheeted dike complex in the northern Samail ophiolite is oriented N-S (355 $010^{\circ}$ ), and it appears to be essentially contemporaneous with the layered gabbros and the Geotimes or V1 lavas [Hopson et al., 1981; Alabaster et al., 1982; Pflumio, 1988]. Lavas of purported arc affinities (V2 lavas) are localized in areas where late mafic dikes intrude the uppermost sections of the ophiolite. Younger dikes that crosscut or intrude mineralized seafloor faults in the Alley are oriented either NW-SE $\left(120^{\circ}-150^{\circ}\right)$ or NE-SW $\left(020^{\circ}\right.$ $030^{\circ}$ ). A similar change in dike orientation from early N-S to crosscutting NW-SE orientations was described in the Haylayn and Rustaq blocks by Buerrier [1990] and Reuber et al. [1990], who attributed this sequence to a propagating rift.

Small, discrete intrusive complexes are common in the northern Samail ophiolite, and these have the structural characteristics of off-axis magma chambers emplaced at shallow depths in the oceanic crust [Alabaster et al., 1982]. These superimpose a secon- 
TABLE 4. Oxygen Isotopic and Petrographic Data for Regional Samples Collected from Wadi Jizi Area (Figure 2),

Wadi Kanut (Figure 2), Wadi Ahin (Figure 2), Musafiyah (near Haylayn) and a Plagiogranite Body near Rustaq

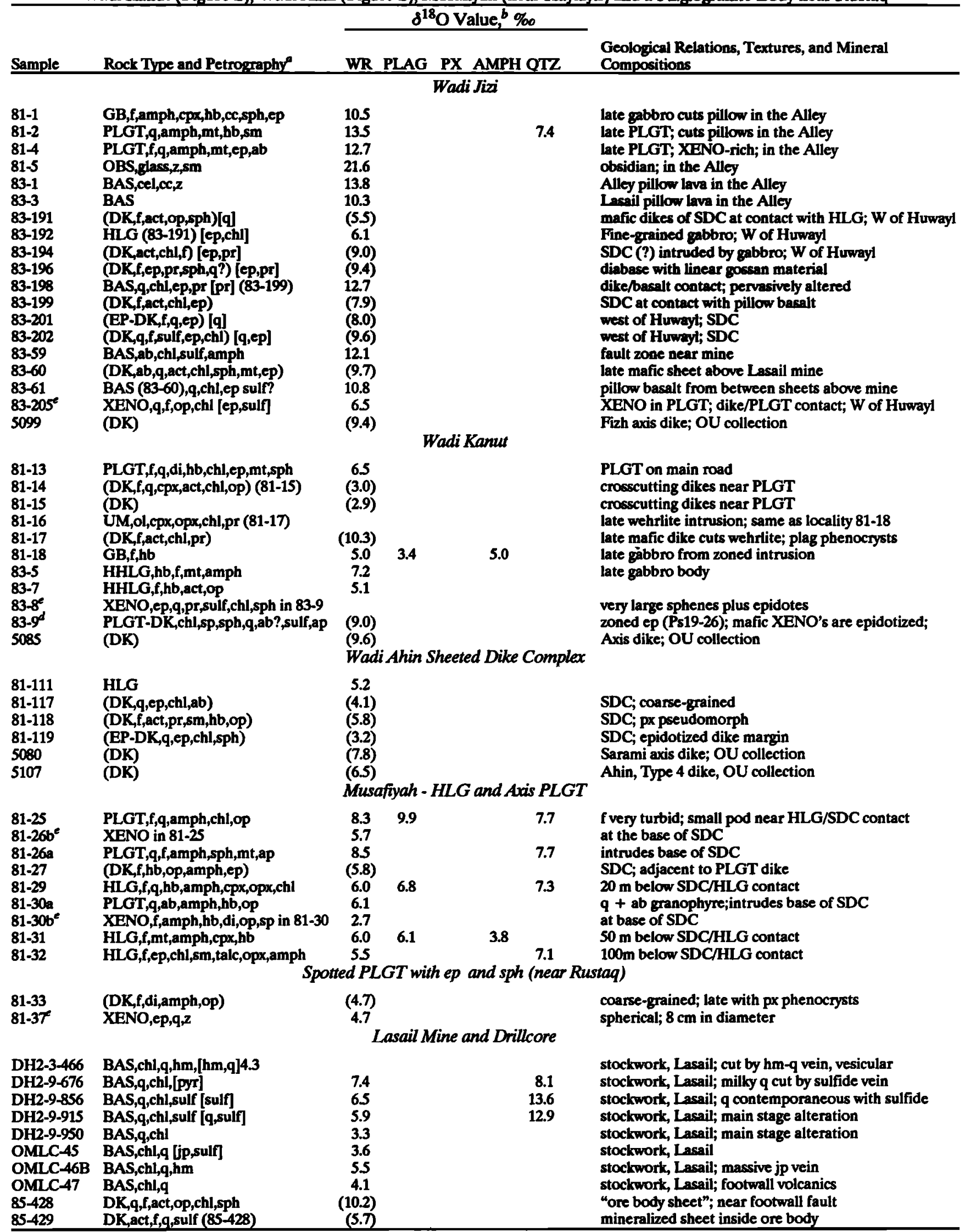

Notes and abbreviations for $\delta^{18} \mathrm{O}$ values, rock names, mineral names and prefixes are same as given for Wadi Rajmi in Table 1, except that jp jasper, hm-hematite; pyr, pyrite; HHLG, very high-level gabbro; OU, Open University, OBS, obsidian; op, opaques; cel, celadonite. 


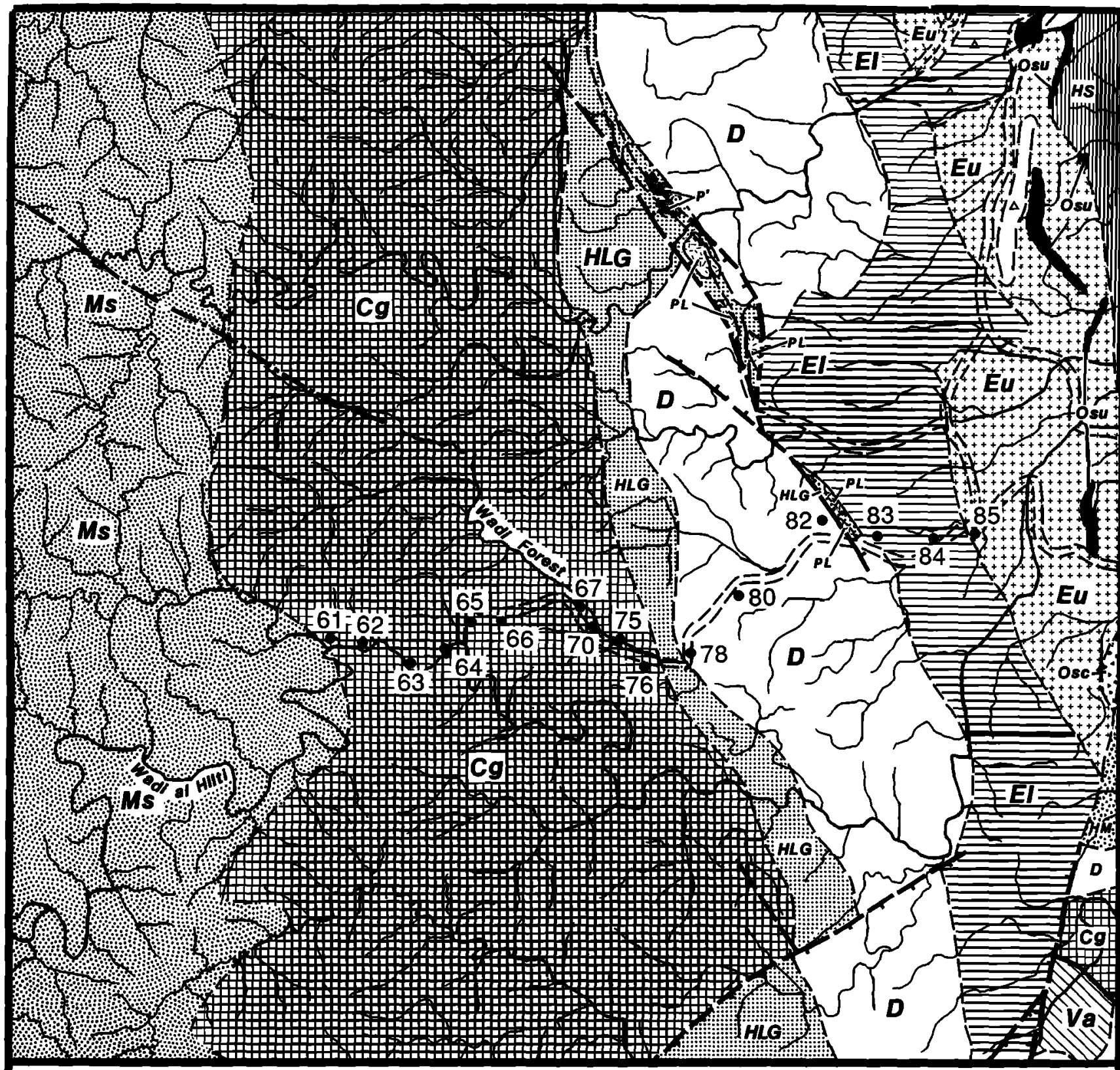

Ms = MANTLE SEQUENCE

$\mathrm{P}^{\prime}=$ LATE PERIDOTITES

HLG = HIGH LEVEL GABBROS

曲 $\mathrm{Cg}=$ CUMULATE GABBROS

$\square \quad D=$ DIKES

OsU $=$ METALLIFEROUS UMBERS

Eu = UPPER LAVAS

$\therefore$ Osc = OPHIOLITIC CONGLOMERATES

冒 $\mathrm{El}=$ LOWER LAVAS

HS = HAWASINA ASSEMBLAGE

$\mathrm{Va}=$ ALKALIC LAVAS

$H M=$ HAWASINA MELANGE

PL $=$ PLAGIOGRANITES

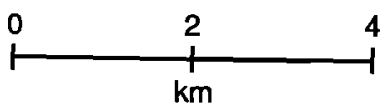

Fig. 3. Simplified geologic map of the Wadi Hilti area (for location see Figure 2), showing sample localities listed in Table 2 (modified after Lippard et al. [1986]). 




Fig. 4. Simplified geologic map of the Wadi Shafan area (for location see Figure 2), showing sample localities listed in Table 3. Map symbols are as follows: A, plagiogranite cuts dikes; B, fine-grained gabbro cut by dikes; C, flaser gabbro and pegmatite; D, pegmatite and plagiogranite; E, layered gabbro with ductile deformation; F, serpentinized ultramafic layers and folded rodingitized felsic layers; $G$, dark massive gabbro cut by epidote and plagiogranite; $\mathbf{H}$, dunite with clinopyroxenite, grading to layered gabbro; d, dikes; $\alpha$, pegmatite, stoped blocks, epidote, and chlorite.

dary metamorphic assemblage on the surrounding country rocks, locally forming abundant quartz, epidote, and sphene. These "magma chambers" are commonly lithologically zoned (wehrlite, isotropic gabbro, plagiogranite, etc.) and shallow-roofed and lo- cally occur well up into the dike complex or the pillow lavas, to within $1-2 \mathrm{~km}$ of the seafloor. The site of intrusion is structurally controlled, that is, the early precursor dikes and veins are all subparallel, and the directions roughly correspond to the major 


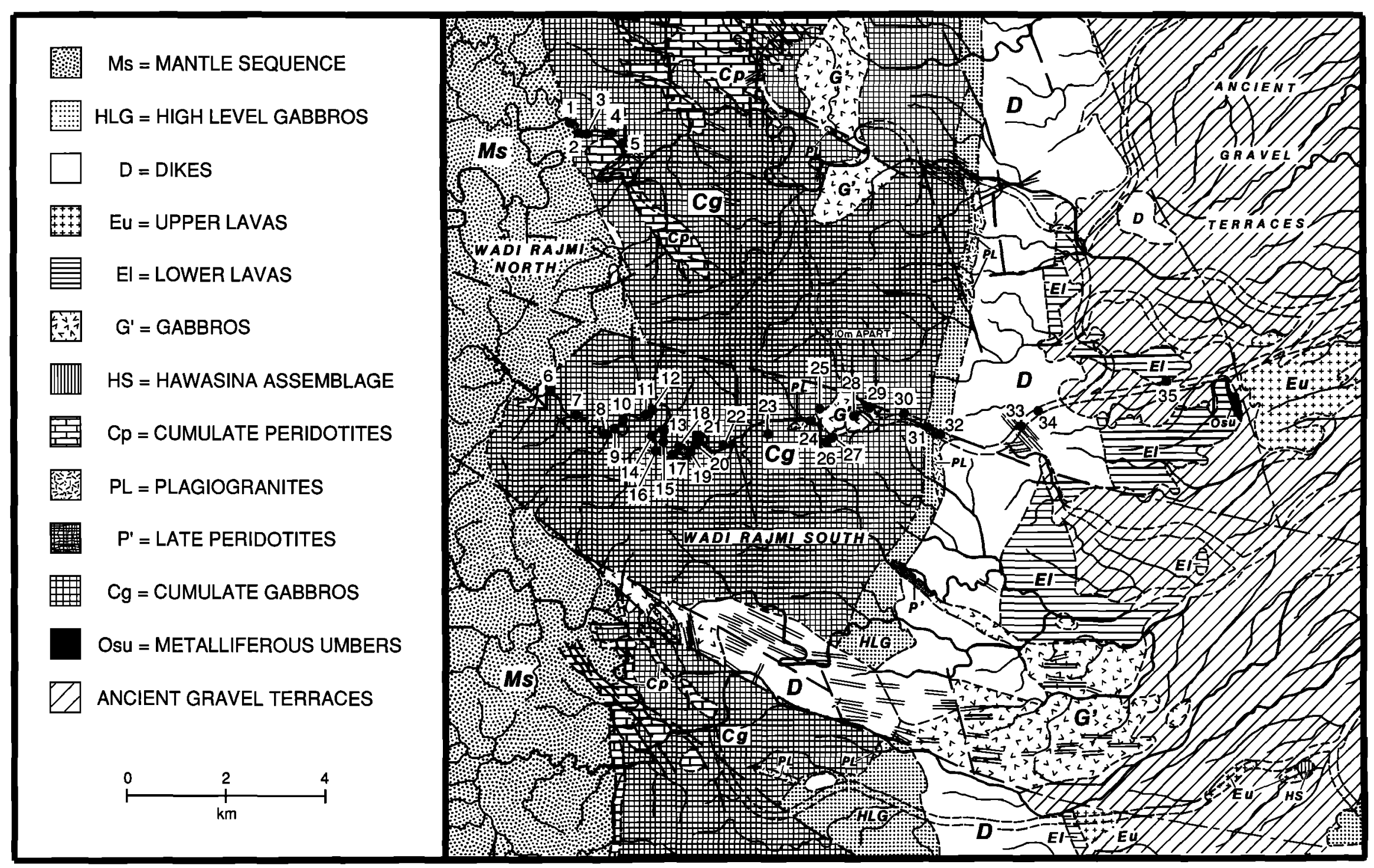

Fig. 5. Simplified geologic map of the Wadi Rajmi area (for location see Figure 2), showing sample localities listed in Table 1 (modified after Lippard et al. [1986]). 


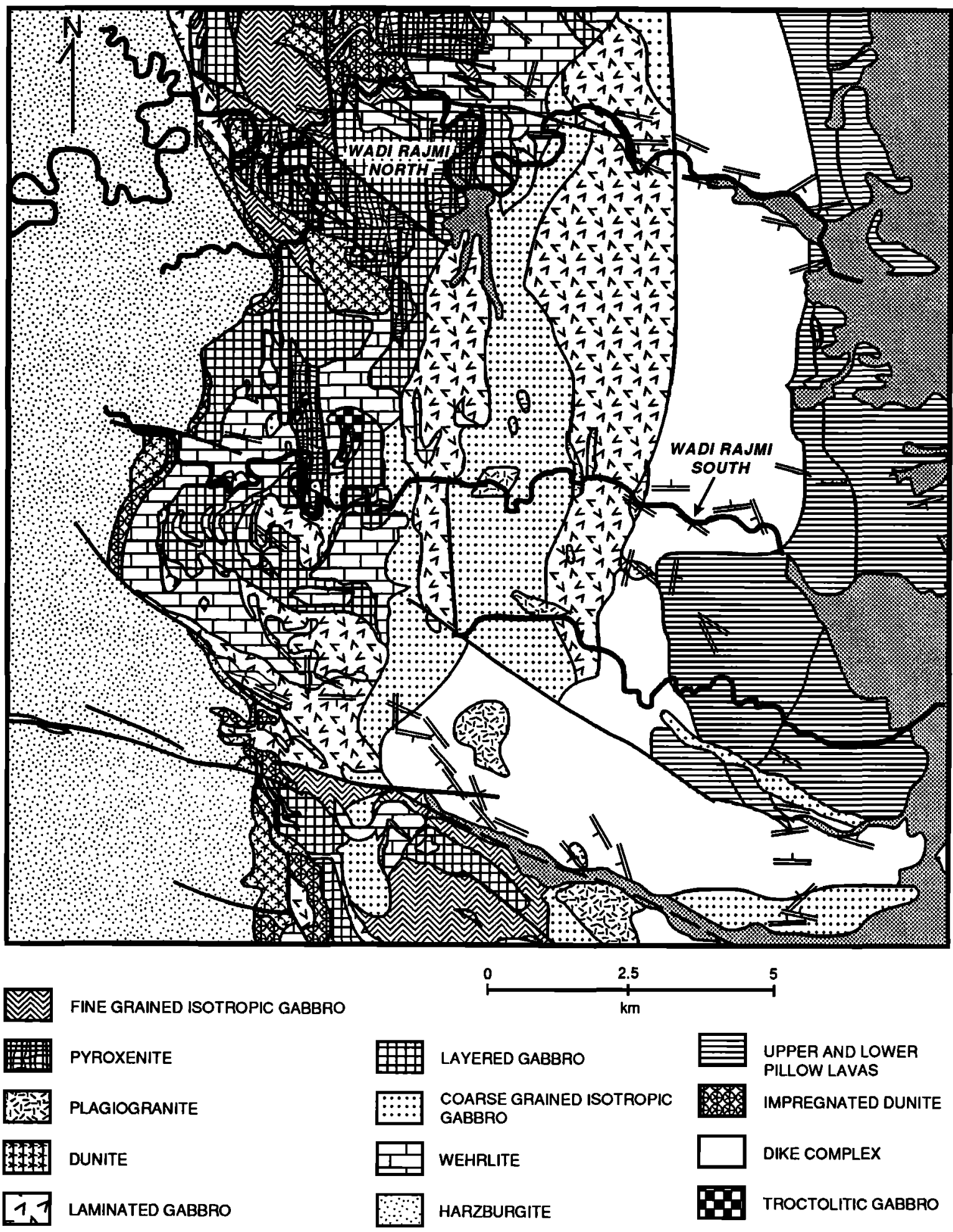

Fig. 6. Simplified geologic map of the Wadi Rajmi area (the same area shown in Figure 5), based on the geologic work of Reuber [1988].

directions of the paleotransform stress field, either ridge or transform parallel. These structural relationships are perhaps analogous to those described by Batiza and Vanko [1983] for seamounts constructed near the intersections of spreading axes and transform faults. The mineralogies and conspicuous heterogeneous textures of the margins and renolith-rich portions of these "off-axis" intrusions are virtually identical to those of the isotropic gabbros of the "intact" or "axis" part of the section; however, the relative proportions of the various lithologies are different.

\section{Wadi Hilti Traverse ("Intact Oceanic Crust")}

The Wadi Hilti transect (Figure 3, and Table 2) represents our attempt to sample the least deformed, least complex, and structurally most pristine cross section available in the northern Samail 
ophiolite, and below we shall refer to this as "intact oceanic crust." Nicolas et al. [1988b] report that in this area the ophiolite is unaffected by tectonic disturbance, the Moho contact is flat and sharp, and the dike complex is systematically oriented N-S. In the Wadi Hilti area, there are none of the large silicic intrusions or deep seafloor fault systems that disrupt the cumulate gabbros in the other transects (Figure 3), although small wehrlite intrusions are fairly common. The Wadi Hilti section contains a $5-\mathrm{km}$ thickness of layered gabbro topped by a relatively thin (100 m thick) unit of isotropic gabbro containing very small plagiogranite segregations, which is in turn overlain by a 2-km-thick section of sheeted dikes and pillow lavas.

The basal cumulates in Wadi Hilti are typically clinopyroxene gabbro or olivine gabbro. These appear to be pristine in hand sample, although petrographic study invariably reveals minor hornblende and accessory chlorite, serpentine, epidote, zeolite, and an unidentified calc-silicate mineral. Commonly, about 5$15 \%$ of the primary mineralogy is replaced by secondary minerals, of which about $2-5 \%$ is hornblende. There is little evidence of plastic deformation or of aluminous hornblende as a vein mineral. One cataclastically deformed layered gabbro $(81-207)$ is the only sample from the layered gabbros found to contain sodic plagioclase (An56), as well as a higher proportion of secondary minerals such as Fe-chlorite and epidote (Table 2). Primary plagioclase is generally An86-91; the most calcic plagioclase occurs as reversely zoned rims of grains in 81-202. Clinopyroxene is locally replaced by actinolitic hornblende, actinolite, and Fe-rich chlorite, even in some of the lower cumulate gabbros. Blebs of green fibrous magnesio-hornblende are observed in the plagioclase. Samples from deep in the crustal section locally contain small amounts of a calcic zeolite (probably laumontite) whereas prehnite and a second unidentified Ca-silicate fill veins in the shallower rocks.

The Wadi Hilti traverse contains a smaller proportion of latestage, hydrous minerals than the other two transects described below, but much more than the corresponding section in the southern part of the ophiolite. In the Ibra gabbros, hornblende is present only as a trace mineral (except in the high-level isotropic gabbros), and prehnite, chlorite, actinolite, and zeolites are present only locally [Pallister and Hopson, 1981; Gregory and Taylor, 1981].

\section{Wadi Shafan-Kanut Traverse ("Complex Oceanic Crust")}

The Wadi Shafan-Kanut transect is made up of only a thin zone of $2.5 \mathrm{~km}$ of cumulate gabbro and a correspondingly much greater relative thickness of sheeted dikes, perhaps as a result of repetition of this part of the section by faulting (Figure 4). In Wadi Kanut, just to the north of the Wadi Shafan area, a large, conposite gabbro-plagiogranite intrusion is intruded into the sheeted dike complex (Figure 2). Combined with the complex set of intrusions that crop out in the vicinity of the contact between the layered gabbros and the sheeted dikes in Wadi Shafan, this makes the upper levels of the Shafan-Kanut oceanic crustal section much more complex than the sections at Wadi Hilti or to the south in the Ibra area. Although the origin of these intrusions is controversial, they are clearly a late stage phenomenon; they probably represent an off-axis intrusive episode.

Numerous faults offset the upper $100 \mathrm{~m}$ of the cumulate gabbro section in Wadi Shafan, and smaller deformation zones locally penetrate more deeply into the gabbro section. The lower gabbros contain discontinuous layers of wehrlite, dunite, and sheared peridotite. A major right-lateral fault separates intact cumulate gabbros from the isotropic high-level gabbros and sheeted dikes (Figure 4). Within this shear zone, the upper gabbro cumulates are remobilized and strongly deformed, with serpentine and calcsilicate assemblages replacing mafic and felsic layers, respectively. Adjacent gabbro layering is broken, boudinaged, and rotated parallel to the shear zone. Gabbros within the shear zone have a spotted "leopard" or flaser texture with a foliation oriented parallel to the shear, and are epidotized where cut by the fault. Quartz-epidote veins and late hornblende-pegmatoidal veins also parallel the shear zone.

Adjacent to this major shear zone in Wadi Shafan, a 2 to 3-km-wide plagiogranite body intrudes the high-level gabbros and the lower part of the sheeted dike complex. Stoped fragments of the diabase dikes are partially resorbed, and the xenolith margins are replaced by fine-grained intergrowths of quartz and epidote. Near the margins of the plagiogranite body, the isotropic gabbro is intensely altered to epidote, thullite, prehnite, hornblende, and sphene, locally producing a homogeneous "spotted" texture as the result of replacement of clinopyroxene by aggregates of green hornblende. Within xenoliths and at the contact, the amphibole "spots" are replaced by epidote. Small faults around the plagiogranite bodies are filled with abundant quartz, as well as massive epidote, prehnite, and sulfides (including chalcopyrite).

Cumulates in Wadi Shafan are typically clinopyroxene gabbro or olivine gabbro replaced by $5 \%-40 \%$ hydrous secondary phases, with the average around $20 \%$. Secondary mineral compositions are similar to those observed in Wadi Hilti samples, but the alteration minerals are much more abundant in Wadi Shafan. The early stage of alteration is associated with 3-25\% amphibole. Later stages involved an increasing quantity of secondary minerals adjacent to major shear zones, with even slightly deformed samples usually thoroughly replaced. Proximity to these shear zones is also associated with late low-temperature microfractures filled with chlorite-quartz, chlorite-prehnite, prehnite, and zoisite.

The two lowermost cumulate gabbros, a "fresh" (81-121) and a highly-altered sample (81-122) (Table 3), were collected just above the cumulate ultramafic rocks and about $100 \mathrm{~m}$ above the Moho. In the "fresh-appearing" sample, $5 \%$ of the clinopyroxene has brown rims of hornblende, $10-15 \%$ of the clinopyroxene has been replaced by green hornblende and pale tremolite-actinolite, and green amphibole replaces the plagioclase and clinopyroxene margins (Tables 3 and 7). The highly altered sample 81-122 displays a similar alteration pattern, and the greater abundances of secondary minerals made it possible to carry out detailed electron microprobe identifications. Sample 81-122 is more than $50 \%$ recrystallized to green amphiboles and untwinned plagioclase. Clinopyrozene is low Ti-endiopside replaced by actinolite-tremolite (1-2\% Al) and actinolitic hornblende. Margins of clinopyroxene and plagioclase are replaced by actinolitic hornblende containing $4-6 \% \mathrm{Al}_{2} \mathrm{O}_{3}$, with greener portions of the amphibole higher in $\mathrm{Fe}$ and $\mathrm{Al}$ (Table 7). The association of magnesio-hornblende and anorthite is typical at the margins between plagioclase grains. Radial bundles of green magnesiohornblende are associated with turbidity in the plagioclase (An86An90 to An97-An99). The anorthite is interpreted as a metamorphic replacement, with $\mathrm{Na}$ and $\mathrm{K}$ removed and excess Ca added (see Table 5). An atypical, more sodic, altered rim (An79) contains 7\% K-feldspar component, compared to typical values of $<1 \%$. Thin blocky microveins of a mixture of Fe-rich chlorite and quartz and tremolite fill some intergranular spaces, probably as a replacement of amphibole. The least altered layered gabbro in Wadi Shafan is 81-124, an olivine gabbro with clear, twinned, and unzoned plagioclase, containing a tiny amount 
of green fibrous amphibole. Dark brown hornblende is evident as rims on the clinopyroxene, and some of the clinopyroxene grains contain zones of secondary pyroxene.

The stratigraphically highest layered gabbro (81-128, Table 3), collected just below the megashear and deformed gabbros, contains olivine pseudomorphs of saponite or smectite $(6-7 \% \mathrm{Al})$ which have parallel extinction (Table 9). In addition to the ubiquitous amphiboles, microfractures are filled with Fe-rich chlorite and prehnite. The plagioclase (An80 to An82 with some reverse zoning to An85) is partially saussuritized and up to $10 \%$ replaced by fine-grained amphibole. The isotropic gabbros in Wadi Shafan adjacent to the plagiogranite body contain abundant: 1) clear brown hornblende (up to $4 \% \mathrm{Al}_{2} \mathrm{O}_{3}$ ), either primary or replacing clinopyroxene; 2) fibrous green actinolitic hornblende and actinolite, or actinolite plus prehnite replacing clinopyroxene and brown hornblende; 3 ) sphene replacing ilmenite; and 4) epidote ( $3 \%-4 \% \mathrm{Fe})$, thullite, and prehnite ( $1 \% \mathrm{Fe}$ ) replacing plagioclase. These secondary minerals are concentrated in quartz-bearing pegmatoidal pods characteristic of the high-level section. These isotropic gabbros are crosscut by quartz and quartz-epidote veins, some of which contain the cojdized relicts of copper sulfide minerals. The vein mineral compositions are greatly enriched in Fe compared to the adjacent host gabbro. A vein sampled near the margin of the plagiogranite contains strongly zoned, pleochroic epidote (11\%-14\% FeO) and prehnite (up to $3 \%$ FeO). An oxidized sulfide and secondary green phyllosilicate within the same vein contains $10-15 \%$ CuO.

\section{Wadi Rajmi Traverse ("Fossil Transform")}

We made a detailed study of the Wadi Rajmi transect, expressly because it had been originally identified as the possible site of a fossil transform zone [Smewing, 1980]. Evidence for the transform model includes the appearance of a second set of dikes in this region that are oblique to the dike complex of the main ophiolite; these oblique dikes are generally oriented NW-SE at about $120^{\circ}$. There is also the appearance of numerous high temperature shear zones that have strike-slip features. However, later studies by French workers did not observe mantle petrofabrics to support this contention (T. Juteau, personal communication, 1985). Reuber [1988] presents some arguments that this region might be a paleo-overlapping spreading center (OSC) complicated by intraoceanic thrusting (detachment) at or very near the ridge. This interpretation implies that this shearing took place while the rocks were at very high temperatures $\left(-1000^{\circ} \mathrm{C}\right.$, according to Boudier et al. [1985]. A number of major east trending fault zones are found just north of the area shown in Figure 6; these are considered to be extensional features by Reuber [1988]. She suggests that these features guided the wehrlite and plagiogranite intrusions, the east trending dikes, and the hydrothermal circulation associated with these magma bodies. Reuber [1988] suggests that the magmatic and tectonic characteristics of the Rajmi area are gradational to those in the south, which would not be expected at a major transform boundary separating independent magmatic systems. Regardless of the exact interpretation, the Wadi Rajmi area is clearly a zone where intense fracturing and shearing took place at, or just after, the time of formation of this section of oceanic crust. Our samples are from two wadis separated by about $6 \mathrm{~km}$ (Figures 5 and 6).

The lower part of the Rajmi plutonic section is very complex, and it is difficult to estimate a true stratigraphic thickness; however, from the steeply dipping harzburgite contact to the base of the sheeted dike complex represents a stratigraphic thickness of at least $4 \mathrm{~km}$, and this section is overlain by about $2-3 \mathrm{~km}$ of sheeted dikes and pillow lavas, giving the Wadi Rajmi section a relatively "normal" oceanic crustal thickness in spite of its complexity [see Reuber, 1988]. The plutonic section in the Rajmi area is unusual for the ophiolite in that it is comprised of almost equal proportions of bimodal mafic and ultramafic cumulates. The mafic cumulates are dominated by two-pyroxene gabbros, rare in other localities in the ophiolite except for Wadi Haymiliyah [Juteau et al., 1988a], which is also suggested to be the distal edge of a magma system. The ultramafic units include feldspathic dunites, wehrlites, and olivine websterites [Smewing, 1981, 1990]. These bimodal units (gabbro/peridotite alternations) occur on a variety of scales from centimeter-scale repetitions to layers a couple of hundred meters thick. Smewing [1981] interprets these ultramafic layers as representing crystallization during abrupt shifts to more primitive magma compositions in an open-system magma chamber; more than a dozen resets were observed in a 500-m-thick section.

Gabbro tectonites and pegmatites cut even the lowermost layered gabbros down to and including the Moho, which dips almost vertically in this area. Layering fabrics have been rotated into shear zones where cataclasis and amphibolite-facies recrystallization have occurred. According to Smewing [1990], the Moho at this locality is acting as a major N-S sinistral shear zone. This is evidenced by a tectonic fabric in the lowermost gabbro, and the fact that the gabbro layering is progressively rotated from a strike of $060^{\circ}$ to due north as the Moho is approached. Dikes of feldspathic peridotite and gabbro pegmatite (1-3 m across) also commonly crosscut the cumulate gabbro layering. Composite wehrlite-gabbro intrusions are common at all levels throughout the layered gabbro section, locally extending upward into the sheeted dikes and pillow lavas.

Our stratigraphically lowest samples are from just above the Moho in Wadi Rajmi North (Figure 5), and include several sheared gabbros and gabbro pegmatites from ultramafic units and the laminated gabbro unit (Figure 6), as defined by Reuber [1988]. This traverse also includes a sample of isotropic gabbro (81-100), here termed DIG (Deep Isotropic Gabbro) to distinguish it from the typical occurrence of this lithology. All of our North Rajmi samples are strongly deformed, except for this later stage DIG intrusion. Highly altered gabbroic rocks were collected from the vicinity of the petrologic Moho, as well as farther upward in the gabbro section. For example, a highly deformed and foliated gabbro cut by a gabbro pegmatite was collected about 15 mabove the Moho; approximately $20 \%$ of the primary plagioclase and clinopyroxene has been replaced by green and brown hornblende. Similarly, a gabbro tectonite collected from $75 \mathrm{~m}$ above the Moho is extensively replaced by green hornblende and is crosscut by a hornblende pegmatite.

All higher-level samples are from Wadi Rajmi South (Figure 5), the lowermost of which are deformed layered gabbros from a complex zone of wehrlite, layered gabbro, troctolitic gabbro, and pyroxenite, together with local occurrences of isotropic gabbro and laminated gabbro, as shown in Figure 6 and as mapped by Reuber [1988]. These lithologies are interlayered with, and crosscut by, a series of amphibole-rich gabbro pegmatites and fine-grained dikes that also contain abundant hydrous minerals (Table 1). Some of these layered gabbros are intensely sheared (e.g., locality 15), and these are typically rich in hydrous alteration minerals. The degree of shearing and the abundance of gabbro pegmatite is much greater in this section of Wadi Rajmi than in the corresponding portion of Wadi Hilti.

In the lower half of the Wadi Rajmi section, within the zone of 
strong ${ }^{18} \mathrm{O}$ depletion (see below), the amphibole content varies from 5 to $40 \%$, averaging about $15 \%$. Above this ${ }^{18} \mathrm{O}$-depleted zone, the amphibole content is $3-60 \%$, with an average of $35-40 \%$. Other, lower-temperature hydrous minerals are also common throughout the section, and locally $70 \%$ of the rock is made up of OH-bearing minerals. The sheared feldspathic wehrlite or dunite, hornblende gabbro pegmatite, and late basaltic dikes all typically crosscut the cumulate gabbro layers at high angles. These late gabbro pegmatite dikes are characterized by abundant orthopyroxene, calcic plagioclase (An95-98), primary brown homblende, and copper-rich sulfides. Undeformed gabbroic rocks adjacent to these late crosscutting features contain veins of coarse green-brown hornblende and talc replacing olivine. Clinopyroxene is up to $50 \%$ replaced by green hornblende. The most extensive metamorphic replacement is adjacent to pegmatite dikes, basaltic dikes, and fault zones.

The Rajmi area is unique in containing the largest mapped zones of so-called laminated gabbro in the Samail ophiolite (Figure 6). In this area a thick zone of isotropic gabbro invaded by plagiogranite bodies is bounded above and below by large stratigraphic units of laminated gabbro; the uppermost of these units extends right up to the SDC contact (Figure 6). These zones of laminated noritic gabbro have many of the characteristics of the same kinds of lithologies described in detail by Juteou et al. [1988a,b], including the association with orthopyroxene, intense veining and fracturing, and gradations into zones of magmatic breccias (localities 23-30, Table 1). The mineralogy and structure of the vein systems in this zone are similar to those described by Nehlig and Juteau [1988].

The late gabbroic intrusions contain abundant orthopyroxene and primary brown amphibole. A medium-sized (1-2 km diameter) composite plagiogranite and isotropic gabbro body is intruded into the top of the gabbro section (localities 24-29), and a smaller plagiogranite body occurs at the base of the sheeted dike complex (locality 32); the latter has an anomalous ESE trend in this part of the ophiolite. Several other plagiogranites are intruded into the upper third of the gabbro section (Figure 6). Similar to Wadi Shafan, the clinopyroxenes in the high-level isotropic gabbros are predominantly altered to green actinolitic hornblende and epidote veins are abundant. Xenoliths of gabbro within the plagiogranites are similarly replaced by amphibole and epidote.

A gabbro collected from near the margin of the larger plagiogranite intrusion shows a metamorphic foliation and is characterized by orthopyroxene replaced by green talc, primary brown hornblende replaced by fibrous ferro-actinolite, strongly zoned plagioclase, and late epidote veins. The plagiogranite contains large quartz crystals and highly pleochroic epidotes (Ps 15), some of which have cores of a mesh of finely intergrown epidote and Fe-chlorite. Unusually fresh plagioclase is An89-93. The smaller plagiogranite body exposed at the base of the sheeted dike complex contains much less epidote. At the top of the gabbro section, a late shear zone cuts through the uppermost gabbros, close to the plagiogranite body and to a zone of late mafic dikes. Hornblende pegmatites and epidote veins cut the sheared gabbro. The epidote has pistacite contents of $20 \%-30 \%$ and is intergrown with quartz and associated with actinolite and actinolitic hornblende.

\section{DISCUSSION OF CHEMICAL COMPOSTTIONS OF MINERALS}

The electron microprobe analyses presented in Tables 5-10 are not meant to be comprehensive; they serve mainly to characterize the samples analyzed for ${ }^{18} \mathrm{O} /{ }^{16} \mathrm{O}$, and to provide a framework for comparison with the more extensive microprobe analyses previously published by Smewing [1981], Browning [1984], Juteau et al. [1988], and Emewein et al. [1988] for the northern Samail ophiolite, and by Pallister and Hopson [1981] for the southern Samail ophiolite.

\section{Plagioclase Compositions}

Representative plagioclase compositions are provided in Table 5. Plagioclases in the gabbro pegmatite dikes and the basal layered gabbros of Wadi Rajmi are extremely calcic, An90-98, consistent with results reported by Smewing [1981] (An90-95 for Rajmi mafic-ultramafic cumulates). Deformed grains of plagioclase that are depleted in ${ }^{18} \mathrm{O}$ are equally calcic in composition. Slightly more sodic compositions (An77-82) are observed in non-layered gabbro crosscut by late stage dikes. The quartzepidote-chlorite assemblage in the discordant "plagiogranite" 8163 contains relict calcic plagioclase whose core compositions (An93) are similar to those found in the Rajmi pegmatoidal intrusives; the smaller plagioclase grains have An87-89.

The Wadi Rajmi plagioclases are the most calcic reported from the Samail ophiolite. For comparison, in the Jabal Dimh area [Pallister and Hopson, 1981], the average cumulate gabbro plagioclase is An70-85, with somewhat more sodic values in the high-level gabbros. The average plagioclase in the northern half of the ophiolite, excluding the Rajmi area, ; about An80-90 [Smewing, 1981; this work]. Our limited data suggest that the later stage intrusions, the crosscutting pegmatoidal dikes, and particularly the feldspathic wehrlites are associated with plagioclase compositions more calcic than An90. Younger intrusions containing more calcic plagioclase are also reported for the Assayab region between Wadi Rajmi and Wadi Hilti, where they are attributed to a hydrous mantle source region [Vetter and Stakes, 1990]. This is similar to what has been proposed for the wehrlitic intrusions that dominate the Rajmi area. Four analyses of different plagioclase grains from the strongly sheared and ${ }^{18} \mathrm{O}$-depleted sample 81-43 show that the bulk of the plagioclase is An98-99 but that smaller, recrystallized grains are An91-94 (Table 5). This sample is particularly interesting because it is from the most ${ }^{18} \mathrm{O}$-depleted outcrop yet found in the Samail ophiolite (see below).

Plagioclase compositions in Wadi Shafan an _ Wadi Hilti were found to be on average less calcic than those from the Rajmi area. Fresh-appearing samples have plagioclase that is An84-An88 in composition and typically unzoned. Heavily altered samples from the lower portions of both of these sections contain secondary calcic plagioclase (An91-98). Syndeformational (metamorphic) plagioclase is more sodic (down to An56), especially in samples with abundant hydrous replacement minerals (e.g. green fibrous amphibole, chlorite, and epidote). This is best illustrated by analyses 15 and 16 from sample 81-207 in Table 5. Analysis 16 is an igneous plagioclase inclusion (An85) within a large primary pyroxene; this feldspar appears to have been "protected" from subsequent aqueous-fluid interaction, based on a comparison with a small sodic neoblast (An58) in a deformation zone that cuts the rock.

Plagioclase of intermediate composition is only common in the uppermost gabbros, or associated with deformation or extensive alteration. Both Pallister and Hopson [1981] and Juteau et al. [1988a] note only minimal cryptic variation in primary mineral phase chemistry, small jumps in composition toward more primitive values are linked to input of more primitive magma into the chamber. Smewing [1981] also notes an abrupt change in 
TABLE 5. Feldspar Compositions

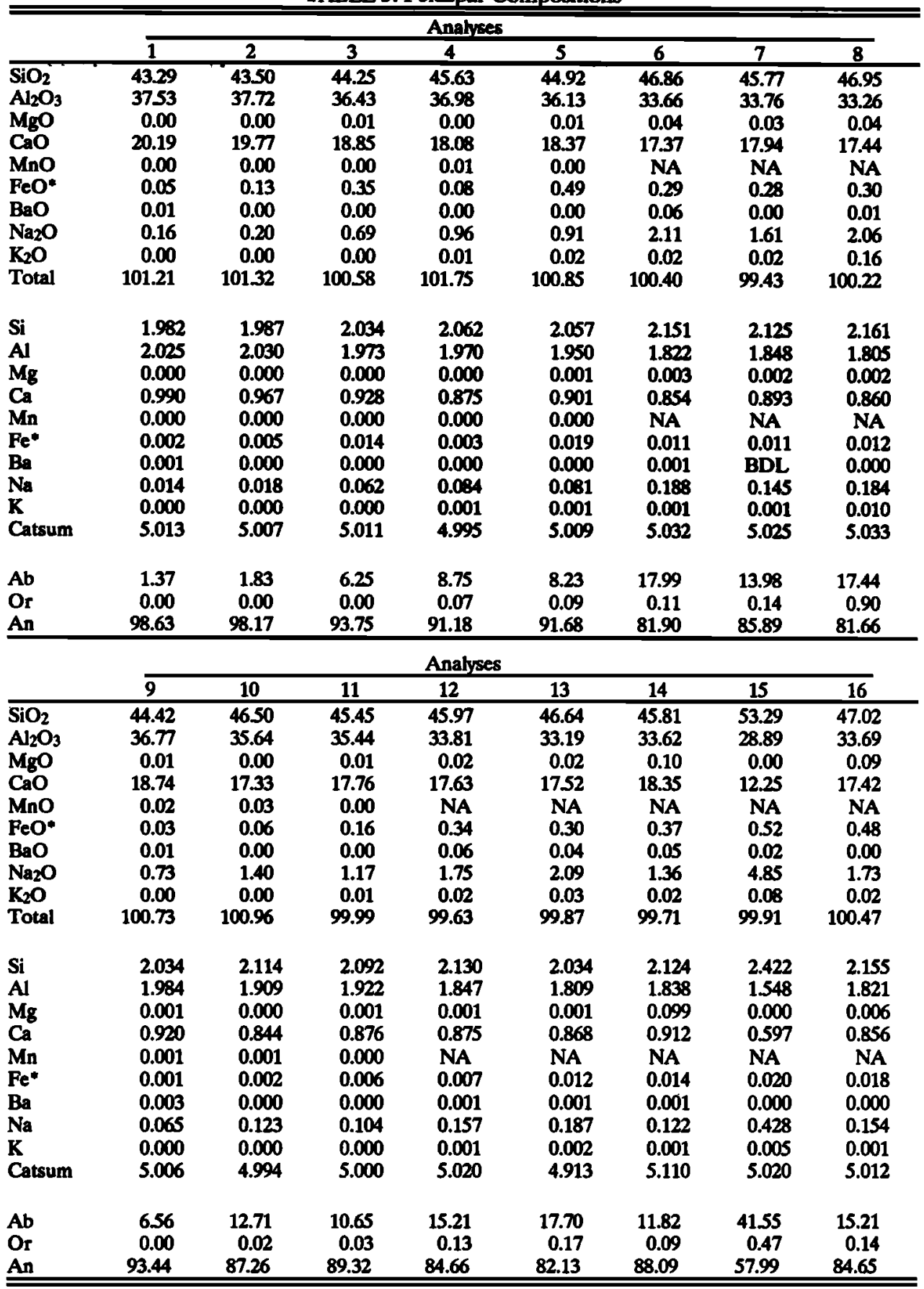

NA, not analyzed; BDL, below detection limit; Analyses: 1, OM81-43 (Rajmi; sheared gabbro) core of large euhedral plagioclase; rim is An95; 2, OM81-43, cut by vein of actinolitic hornblende; adjacent to vein; 3, OM81-43, small plagioclase grain adjacent to brown hornblende; 4, OM81-43, deformed plagioclase with inclusions (nuclei) of actinolitic hornblende; 5, OM81-53 (Rajmi; pegmatitic gabbro), core of large primary plagioclase; 6, OM81-128 (Shafan), core of large plagioclase; 7, OM81-128, edge of previous large grain of plagioclase (slight reverse zonation); 8,0M81-128, average plagioclase composition (average of three); 9 , OM81-63 (Rajmi plagiogranite), core of large plagioclase grain; 10, OM81-63, island of plagioclase in large quartz grain; 11, OM81-63, small grain associated with chlorite and actinolite; 12, OM81-129 (Shafan), clear twinned unzoned grains, average of two; 13, OM81-129 (Shafan), core of fresh plagioclase, average of three; 14, OM81-203 (Hilti), large turbid plagioclase grains, unzoned, average of three; 15, OM81-207 (Hilti), neoblasts in deformed zone in plagioclase, small grains on edge of lange crystal; 16, OM81-207, euhedral plagioclase enclosed in igneous pyroxene.

chemistry between ultramafic and mafic layers in bimodal units, similar to the difference observed in the present study between normal and calcic plagioclase. Pallister and Hopson [1981] showed that the Aqsaybah fault zone is characterized by a much more sodic plagioclase than that of the normal cumulates. The appearance of sodic plagioclase in the ophiolite may thus be correlated with two general hydrothermal processes: (1) concurrent recrystallization during the formation of $\mathrm{Ca}$-rich minerals like 
epidote, actinolite, prehnite, and Ca-zeolites; and (2) deformation and deep penetration of $\mathrm{NaCl}$-rich seawater at high water/rock ratios into the oceanic crust.

The chemical compositions of the plagioclases in the upper parts of the oceanic crustal sections in the Samail ophiolite are obviousty hydrothermal-metamorphic in origin, 28 they are typically much changed from their original Ca-rich magmatic values. In the lower parts of these sections, the plagioclases are much closer in composition to their original magmatic values; nevertheless, it is doubtful that any of these plagioclases have pristine magmatic compositions. The ${ }^{18} \mathrm{O} /{ }^{16} \mathrm{O}$ evidence for their ubiquitous exchange with hydrothermal fluids is clear (see below), so the preservation in the lower cumulates of compositions close to magmatic values is purely a result of the fact that the $\mathrm{Ca} / \mathrm{Na}$ ratios of the deep-circulating fluids are being controlled by the adjacent rock reservoir rather than by the external ocean water reservoir. The presence of apparent hydrothermal plagioclase with very calcic compositions in the deep-seated gabbros is very likely a result of subsolidus exchange between these fluids and the nearby wehrlite intrusions, which have primitive chemical compositions.

\section{Pyrocene Compositions}

The pyroxene compositions given in Figure 7 and Tables $6 a, 6 b$ and $6 c$ are, in general, consistent with data reported by Smewing [1981] and Pallister and Hopson [1981]. The clinopyroxenes have En40-54, and orthopyroxenes from Wadi Rajmi have En70-88. Although most of the compositions can be explained by magmatic crystallization, some of the chemical variations are correlatable with metamorphic events. Secondary pyroxenes (neoblasts?) are less aluminous and more calcic than igneous pyroxenes in the same sample (compare analyses 3 and 4 , Table $6 b$, and analyses

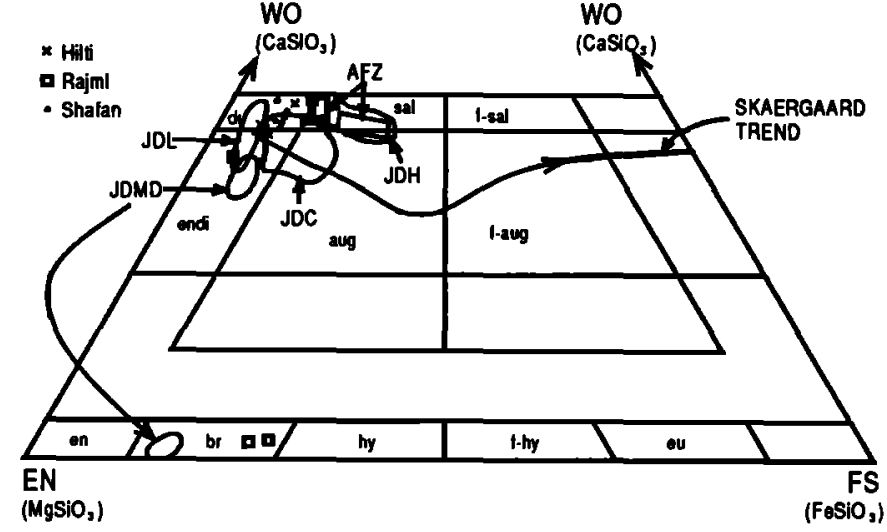

Fig. 7. Pyroxene quadrilateral for formulas based on Papike et al. [1974]. Fields are from the Ibra area in the southern Samail Ophiolite described by Palliser and Hopson [1981], with the following abbreviations: AFZ, Aqseybah Fault Zone; JDH, Jabal Dimh high level gabbros; JDC, Jabal Dimh cumulate gabbros; JDMD, Jabal Dimh mantle dike; JDL, Jabal Dimh lower gabbros. The Stracrgaard fractionation trend is also shown for comparison. Note the similarity in pyroxene compositions in the Wadi Rajmi sheared gabbros and pegmatites compared with those from the Aqsaybah Fault Zone. Note that the Wadi Hilti and Wedi Shafan pyroxenes are mostly within the range of the more enstatite-rich pyrorenes in cumulate gabbros from Jabal Dimh. Diopsidic compositions from Wadi Hilti and Wadi Shafan are metamorphic pyromenes, analogous to certain samples from the Skaergand intrusion studied by Manning and Bird [1986] and Bird et al. [1986].

1 and 2, Table 6a). Dark turbid grains of clinopyroxene (e.g., Table $6 c$, analysis 6 ) and altered rims of large clinopyroxene grains (e.g., Table 6b, analysis 1) commonly have similar calcium-rich, aluminum-poor compositions. The 15 analyzed clinopyroxenes

TABLE 6a. Rajmi Pyrokene Compositions

\begin{tabular}{|c|c|c|c|c|c|c|c|}
\hline & \multicolumn{7}{|c|}{ Analyces } \\
\hline & $\begin{array}{c}1 \\
81-43\end{array}$ & $\begin{array}{c}2 \\
81-43\end{array}$ & $\begin{array}{c}3 \\
81-53\end{array}$ & $\begin{array}{c}4 \\
81-53\end{array}$ & $\begin{array}{c}5 \\
81-53\end{array}$ & $\begin{array}{c}6 \\
81-53\end{array}$ & $\frac{7}{81-101}$ \\
\hline $\begin{array}{l}\mathrm{SiO}_{2} \\
\mathrm{TiO}_{2} \\
\mathrm{Al}_{2} \mathrm{O}_{3} \\
\mathrm{Pe}_{2} \mathrm{O}_{3} \\
\mathrm{FeO} \\
\mathrm{MnO} \\
\mathrm{MgO} \\
\mathrm{CaO} \\
\mathrm{Na2} \mathrm{O} \\
\mathrm{Cr}_{2} \mathrm{O}_{3} \\
\text { Total }\end{array}$ & $\begin{array}{r}53.34 \\
0.10 \\
2.17 \\
0.00 \\
7.04 \\
0.13 \\
16.03 \\
20.03 \\
0.17 \\
0.00 \\
99.02\end{array}$ & $\begin{array}{r}52.35 \\
0.23 \\
1.29 \\
1.49 \\
5.44 \\
0.30 \\
14.48 \\
24.01 \\
0.11 \\
0.00 \\
99.70\end{array}$ & \begin{tabular}{r|}
51.70 \\
0.26 \\
2.06 \\
2.59 \\
5.02 \\
0.20 \\
15.32 \\
22.26 \\
0.22 \\
0.11 \\
99.74
\end{tabular} & $\begin{array}{r}\mathbf{5 0 . 7 2} \\
0.25 \\
2.29 \\
3.03 \\
6.64 \\
0.27 \\
14.06 \\
21.79 \\
0.21 \\
0.05 \\
99.31\end{array}$ & \begin{tabular}{r|}
53.99 \\
0.14 \\
1.72 \\
0.55 \\
17.36 \\
0.32 \\
25.28 \\
1.45 \\
0.02 \\
0.04 \\
100.87
\end{tabular} & $\begin{array}{r}54.55 \\
0.06 \\
1.19 \\
0.81 \\
15.80 \\
0.35 \\
26.50 \\
1.47 \\
0.01 \\
0.06 \\
100.78\end{array}$ & $\begin{array}{r}50.91 \\
0.10 \\
2.44 \\
2.28 \\
2.72 \\
0.20 \\
16.58 \\
21.73 \\
0.14 \\
0.46 \\
97.57\end{array}$ \\
\hline $\begin{array}{l}\mathrm{Si} \\
\mathrm{Ti} \\
\mathrm{Al}^{3+} \\
\mathrm{Fe}^{3+} \\
\mathrm{Fe}^{2+} \\
\mathrm{Mn} \\
\mathrm{Mg} \\
\mathrm{Ca} \\
\mathrm{Na} \\
\mathrm{Cr} \\
\text { Catsum }\end{array}$ & $\begin{array}{l}1.973 \\
0.003 \\
0.095 \\
0.000 \\
0.218 \\
0.004 \\
0.884 \\
0.794 \\
0.012 \\
0.000 \\
3.983\end{array}$ & $\begin{array}{l}1.948 \\
0.007 \\
0.057 \\
0.042 \\
0.169 \\
0.009 \\
0.803 \\
0.958 \\
0.008 \\
0.000 \\
4.000\end{array}$ & $\begin{array}{l}1.918 \\
0.007 \\
0.090 \\
0.072 \\
0.156 \\
0.006 \\
0.847 \\
0.885 \\
0.016 \\
0.003 \\
4.000\end{array}$ & $\begin{array}{l}1.906 \\
0.007 \\
0.102 \\
0.086 \\
0.209 \\
0.009 \\
0.788 \\
0.878 \\
0.015 \\
0.002 \\
4.000\end{array}$ & $\begin{array}{l}1.952 \\
0.004 \\
0.073 \\
0.015 \\
0.525 \\
0.010 \\
1.363 \\
0.056 \\
0.001 \\
0.001 \\
4.000\end{array}$ & $\begin{array}{l}1.962 \\
0.002 \\
0.051 \\
0.022 \\
0.475 \\
0.011 \\
1.420 \\
0.057 \\
0.000 \\
0.002 \\
4.000\end{array}$ & $\begin{array}{l}1.909 \\
0.003 \\
0.108 \\
0.064 \\
0.085 \\
0.006 \\
0.873 \\
0.873 \\
0.010 \\
0.014 \\
4.000\end{array}$ \\
\hline $\begin{array}{l}\text { Wo } \\
\text { En } \\
\text { Fs }\end{array}$ & $\begin{array}{l}41.9 \\
46.6 \\
11.5\end{array}$ & $\begin{array}{r}49.4 \\
41.4 \\
9.2\end{array}$ & $\begin{array}{r}46.7 \\
44.7 \\
8.6\end{array}$ & $\begin{array}{l}46.6 \\
41.9 \\
11.5\end{array}$ & $\begin{array}{r}2.9 \\
69.8 \\
27.4\end{array}$ & $\begin{array}{r}2.9 \\
72.4 \\
24.7\end{array}$ & $\begin{array}{r}46.2 \\
49.0 \\
4.9\end{array}$ \\
\hline
\end{tabular}

Analyses: 1, sheared gabbro; pyroxene cut by epidote vein; 2, diopside neoblast intergrown with brown homblende; 3, relict grain of clinopyroxene; 4, pegmatite; edge of grain adjacent to An93 plagioclase; 5, edge of large orthopyroxene grain adjacent to clinopyroxene 4; 6, large orthopyroxene grain adjacent to clinopyroxene 3; 7, large primary clinopyroxene in pegmatitic gabbro. 
TABLE 6b. Shafan Pyroxene Compositions

\begin{tabular}{|c|c|c|c|c|c|c|c|c|}
\hline & & & & Analys & & & & \\
\hline & $\begin{array}{c}1 \\
81-129\end{array}$ & $\begin{array}{c}2 \\
81-129\end{array}$ & $\begin{array}{c}3 \\
81-129\end{array}$ & $\begin{array}{c}4 \\
81-129\end{array}$ & $\begin{array}{c}5 \\
81-128\end{array}$ & $\begin{array}{c}6 \\
81-128\end{array}$ & $\begin{array}{c}7 \\
81-128\end{array}$ & $\begin{array}{c}8 \\
81-122\end{array}$ \\
\hline$\overline{\mathrm{SiO}_{2}}$ & 54.15 & 52.95 & 52.95 & 54.41 & 53.35 & 53.37 & 53.62 & 5253 \\
\hline $\mathrm{TiO}_{2}$ & 0.16 & 0.62 & 0.26 & 0.16 & 0.36 & 0.34 & 0.40 & 0.27 \\
\hline $\mathrm{Al}_{2} \mathrm{O}_{3}$ & 0.98 & 1.73 & 2.17 & 0.46 & 2.65 & 2.03 & 1.81 & 1.89 \\
\hline $\mathrm{Fe}_{2} \mathrm{O}_{3}$ & 0.00 & 0.00 & 0.00 & 0.00 & 0.00 & 1.41 & 0.00 & 0.23 \\
\hline $\mathrm{FeO}$ & 2.86 & 4.30 & 3.96 & 3.81 & 4.33 & 2.77 & 3.78 & 4.57 \\
\hline $\mathrm{MnO}$ & 0.06 & 0.10 & 0.04 & 0.10 & 0.10 & 0.07 & 0.09 & 0.11 \\
\hline $\mathrm{MgO}$ & 15.95 & 15.87 & 15.73 & 16.18 & 16.51 & 17.27 & 16.38 & 15.92 \\
\hline $\mathrm{CaO}$ & 24.12 & 22.26 & 22.38 & 2350 & 22.21 & 22.11 & 22.66 & 22.50 \\
\hline $\mathrm{Na}_{2} \mathrm{O}$ & 0.18 & 0.38 & 0.29 & 0.27 & 0.31 & 0.47 & 0.36 & 0.25 \\
\hline $\mathrm{Cr}_{2} \mathrm{O}_{3}$ & 0.26 & 0.23 & 0.44 & 0.16 & 0.27 & 0.38 & 0.43 & 0.30 \\
\hline Sum & 98.71 & 98.43 & 98.22 & 99.05 & 100.07 & 100.23 & 99.52 & 98.57 \\
\hline $\mathbf{S i}$ & 1.996 & 1.965 & 1.965 & 2.004 & 1.944 & 1.939 & 1.964 & 1.953 \\
\hline $\mathbf{T i}$ & 0.005 & 0.017 & 0.007 & 0.004 & 0.010 & 0.009 & 0.011 & 0.008 \\
\hline Al & 0.043 & 0.076 & 0.095 & 0.020 & 0.114 & 0.087 & 0.078 & 0.083 \\
\hline $\mathrm{Fe}^{3+}$ & 0.000 & 0.000 & 0.000 & 0.000 & 0.000 & 0.039 & 0.000 & 0.142 \\
\hline $\mathrm{Fe}^{2+}$ & 0.088 & 0.133 & 0.123 & 0.117 & 0.132 & 0.084 & 0.116 & 0.003 \\
\hline $\mathbf{M n}$ & 0.002 & 0.003 & 0.001 & 0.003 & 0.003 & 0.002 & 0.003 & 0.003 \\
\hline $\mathbf{M g}$ & 0.876 & 0.877 & 0.870 & 0.888 & 0.897 & 0.935 & 0.894 & 0.882 \\
\hline $\mathrm{Ca}^{-}$ & 0.953 & 0.885 & 0.890 & 0.928 & 0.867 & 0.861 & 0.889 & 0.896 \\
\hline $\mathbf{N a}$ & 0.013 & 0.027 & 0.021 & 0.019 & 0.022 & 0.033 & 0.026 & 0.018 \\
\hline $\mathrm{Cr}$ & 0.008 & 0.007 & 0.013 & 0.005 & 0.008 & 0.011 & 0.012 & 0.009 \\
\hline Catsum & 3.981 & 3.990 & 3.984 & 3.989 & 3.996 & 4.000 & 3.993 & 4.000 \\
\hline Wo & 49.7 & 46.7 & 47.3 & 48.0 & 45.7 & 45.8 & 46.8 & 46.7 \\
\hline En & 45.7 & 46.3 & 46.2 & 46.0 & 47.3 & 49.7 & 47.1 & 45.9 \\
\hline Fs & 4.6 & 7.0 & 6.5 & 6.1 & 7.0 & 45 & 6.1 & 7.4 \\
\hline
\end{tabular}

Anabyses: 1, slightly altered pyroxene; 2, large grain; 3, turbid grain; 4, secondary pyroxene, islands in pseudomorph; 5 , core of large grain with exsolution lamellae and blebs of hornblende; 6 , edge of same grain as sample $5 ; 7$, edge of large grain; 8 , rounded grain of clinopyroxene in plagioclase.

TABLE 6c. Hilti Pyroxene Compositions

\begin{tabular}{|c|c|c|c|c|c|c|c|}
\hline & \multicolumn{7}{|c|}{ Analyses } \\
\hline & $\begin{array}{c}1 \\
81-207\end{array}$ & $\begin{array}{c}2 \\
81-207\end{array}$ & $\begin{array}{c}3 \\
81-207\end{array}$ & $\begin{array}{c}4 \\
81-202\end{array}$ & $\stackrel{5}{81-202}$ & $\begin{array}{c}6 \\
81-206\end{array}$ & $\begin{array}{c}7 \\
81-203\end{array}$ \\
\hline$\overline{\mathrm{SiO}_{2}}$ & 53.00 & 53.42 & 53.51 & 53.31 & 53.21 & 53.60 & 5250 \\
\hline $\mathrm{TiO}_{2}$ & 0.28 & 0.32 & 0.29 & 0.22 & 0.26 & 0.21 & 0.29 \\
\hline $\mathrm{Al}_{2} \mathrm{O}_{3}$ & 1.89 & 2.23 & 2.27 & 224 & 1.59 & 0.98 & 2.40 \\
\hline $\mathrm{Fe}_{2} \mathrm{O}_{3}$ & 0.58 & 0.11 & 0.93 & 1.31 & 0.98 & 0.04 & 0.62 \\
\hline $\mathrm{FeO}$ & 5.31 & 4.17 & 2.98 & 2.88 & 3.19 & 4.47 & 3.78 \\
\hline MnO & 0.20 & 0.17 & 0.00 & 0.05 & 0.19 & 0.16 & 0.11 \\
\hline $\mathrm{MgO}$ & 16.13 & 17.30 & 17.96 & 16.50 & 16.44 & 1556 & 18.39 \\
\hline $\mathrm{CaO}$ & 21.98 & 21.85 & 22.13 & 23.88 & 23.72 & 24.19 & 19.85 \\
\hline $\mathrm{Na}_{2} \mathrm{O}$ & 0.26 & 0.22 & 0.20 & 0.22 & 0.17 & 0.20 & 0.20 \\
\hline $\mathrm{C}_{2} \mathrm{O}_{3}$ & 0.12 & 0.13 & 0.00 & 0.28 & 0.27 & 0.05 & 0.94 \\
\hline Total & 99.74 & 99.91 & 100.26 & 100.88 & 100.00 & 99.45 & 99.07 \\
\hline Si & 1.951 & 1.947 & 1.938 & 1.932 & 1.947 & 1.979 & 1.925 \\
\hline $\mathrm{Ti}$ & 0.008 & 0.009 & 0.008 & 0.006 & 0.007 & 0.006 & 0.008 \\
\hline Al & 0.082 & 0.096 & 0.097 & 0.096 & 0.068 & 0.043 & 0.104 \\
\hline $\mathrm{Fe}^{3+}$ & 0.016 & 0.003 & 0.025 & 0.036 & 0.027 & 0.001 & 0.017 \\
\hline $\mathrm{Fe}^{2+}$ & 0.163 & 0.127 & 0.090 & 0.087 & 0.098 & 0.138 & 0.116 \\
\hline $\mathbf{M n}$ & 0.006 & 0.005 & 0.000 & 0.002 & 0.006 & 0.005 & 0.003 \\
\hline $\mathbf{M g}$ & 0.885 & 0.940 & 0.969 & 0.891 & 0.897 & 0.856 & 1.005 \\
\hline $\mathrm{Ca}$ & 0.867 & 0.853 & 0.859 & 0.927 & 0.930 & 0.957 & 0.780 \\
\hline $\mathrm{Na}$ & 0.019 & 0.015 & 0.014 & 0.015 & 0.012 & 0.014 & 0.014 \\
\hline $\mathrm{Cr}$ & 0.003 & 0.004 & 0.000 & 0.008 & 0.008 & 0.001 & 0.027 \\
\hline Catsum & 4.000 & 4.000 & 4.000 & 4.000 & 4.000 & 4.000 & 4.000 \\
\hline Wo & 45.3 & 44.4 & 44.8 & 48.7 & 48.3 & 49.0 & 41.0 \\
\hline En & 46.2 & 49.0 & 50.5 & 46.8 & 46.6 & 43.9 & 52.9 \\
\hline Fs & 8.5 & 6.6 & 4.7 & 4.6 & 5.1 & 7.1 & 6.1 \\
\hline
\end{tabular}
Analyses: 1, large pyroxene enclosing plagioclase; 2 , large pyroxene enclosing plagioclase; 3 , fresh euhedral
pyroxene; 4, pale green clinopyroxene; 5 , rim of clinopyroxene with exsolution lamellae; 6 , core of dark turbid pyroxene; 7 , fresh-appearing pyroxene adjacent to vein. 
from Shafan and Hilti are all fairly similar, with Fs contents of 4.6 clinopyroxenes analyzed in the present study are within the range to 8.5 and $\mathrm{Al}_{2} \mathrm{O}_{3}=0.98$ to 2.65. However, most of the analyzed of compositions established by these previous studies, and thereRajmi clinopyroxenes are much more Fe-rich, with Fs $=8.6$ to fore most of the pyroxene grains seem to have preserved their 11.5 (Table 6a). Most orthopyroxene observed in samples from original magmatic or near-magmatic chemical compositions; the Wadi Rajmi is replaced by Fe-Mg amphibole or tremolite. Two hydrothermal metamorphic effects in the pyraxenes are, in representative analyses from sample 81-53 are provided in Table general, confined to obvious recrystallization zones.

6a; these are En70-72 in composition, significantly more Fe-rich The few exceptions to the above generalization typically fall in than the range of compositions (En 80-90) reported by Smewing the field of diopsides or salites. Petrographically, these [1981] for this area.

anomalous clinopyroxene compositions are observed as rims on

Based on the present study and earlier work, the compositions larger igneous pyroxenes or as neoblasts aseociated with sodic of pyroxene in the Samail ophiolite are much more uniform than plagioclase or green-brown hornblende. Pyroxenes with similarly those of plagioclase. Cryptic variations in the igneous pyroxenes salitic compositions are also characteristic of the Aqsaybah fault are small, and readily related to magmatic features in the layered zone in the Wadi Kadir area of the southern ophiolite (Figure 7). gabbros [e.g., Smewing, 1981]. This limited cryptic variation in We suggest that these low-aluminum, low-titanium, high-calcium clinopyroxene was, in fact, used by Pallister and Hopson [1981] as clinopyroxenes are metamorphic in origin and likely are related to evidence for open-system magmatic fractionation. Most of the crustal deformation in the presence of high-temperature hydro-

TABLE 7a. Rajmi Amphibole Compositions

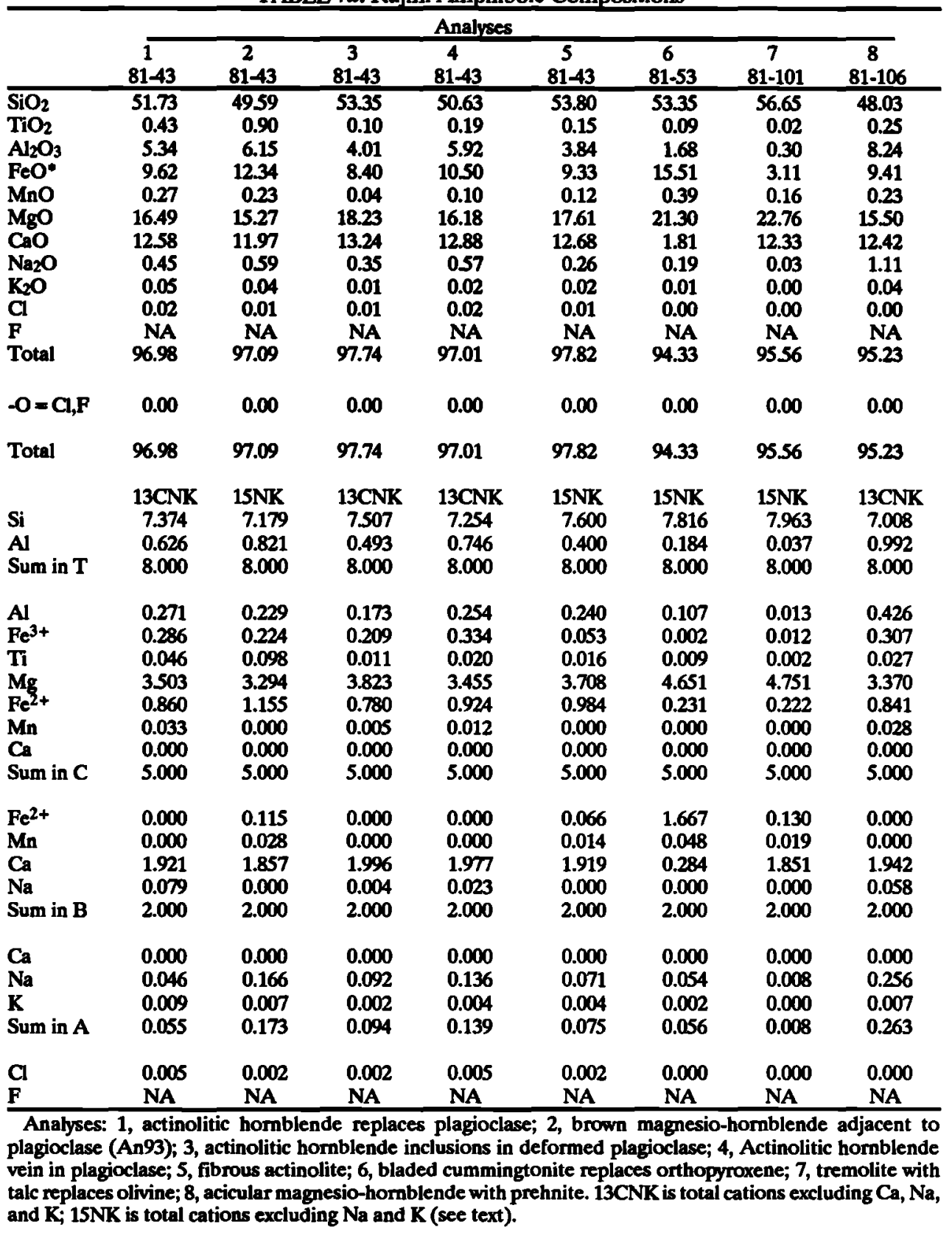


TABLE 7b. Shafan Amphibole Compositions.

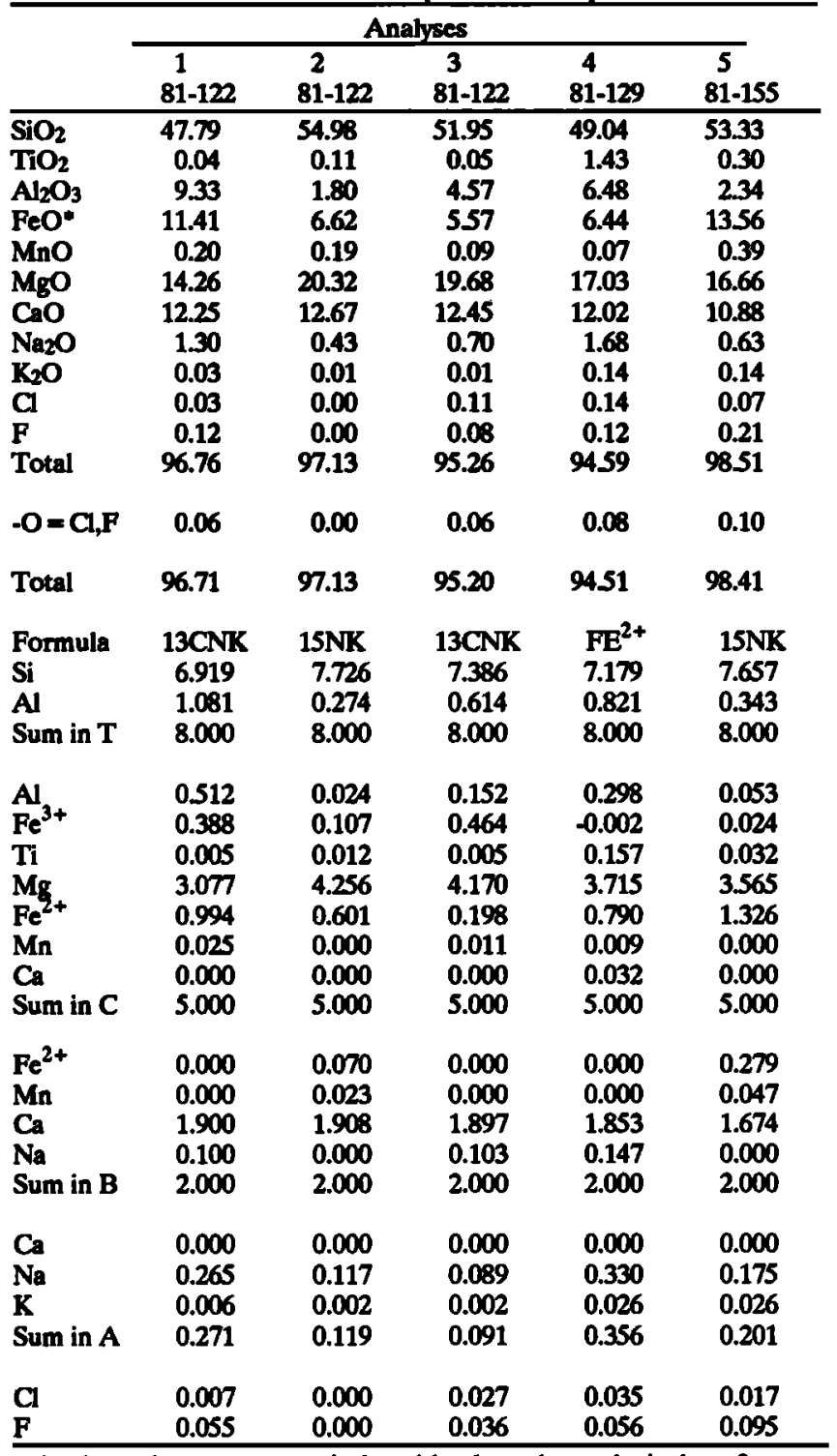

Analyses: 1, green magnesio-hornblende replaces plagioclase; 2, green actinolite replaces pyroxene grain boundaries; 3 , pale green to colorless fibrous actinolitic hornblende replaces plagioclase-pyroxene margins; 4, euhedral brown magnesio-homblende cut by prehnite vein; 5 , greenbrown actinolite rim on clinopyroxene.

thermal fluids. Hydrothermal-metamorphic clinopyroxenes of similar composition have been described by Bird et al. [1986] and Manning and Bird [1986] from the Skaergaard intrusion.

Preservation of near-magmatic chemical compositions in the ophiolitic pyroxenes was a priori to be expected, because it is well known that it is very difficult to exchange the ${ }^{18} \mathrm{O} /{ }^{16} \mathrm{O}$ of pyroxenes during static hydrothermal alteration [e.g., Taylor and Forester, 1979; Gregory et al., 1989]. Only if there is obvious recrystallization, replacement, or vein deposition in a fracture, do we expect to observe pronounced changes in either ${ }^{18} \mathrm{O} /{ }^{16} \mathrm{O}$ or chemical composition of pyroxene.

\section{Amphibole Compositions}

The calcic amphiboles shown in Table 7 and Figure 8 range from actinolite to magnesio-hornblende, using the formulas based on estimated $\mathrm{Fe}^{+2} / \mathrm{Fe}^{+3}$ distribution, as previously described. If all the iron was ferrous, a few mineral species would be considered to be ferro-actinolite or ferroan pargasitic hornblende. Assigning a portion of the iron to ferric iron effectively increases the value of $\left.[\mathrm{Mg}] / \mathrm{Mg}+\left(\mathrm{Fe}^{+2}\right)\right]$, the vertical axis in Figure 8. Using a reasonable assumption for the ferrous-ferric ratio produces formulas that include no ferroan compositions, no edenitic compositions, and only a single pargasitic hornblende.

Actinolite and actinolitic hornblende are the most common amphibole replacement of clinopyroxene or clinopyroxeneplagioclase grain boundaries. Light green amphibole observed as patches or small veinlets cutting plagioclase is typically an aluminous magnesio-hornblende. Cummingtonite is observed to replace orthopyroxene (e.g., Table 7a, analysis 6) and tremolitetalc to replace olivine (e.g., Table $7 a$, analysis 7 ). The greenbrown hornblende typically intergrown with plagioclase neoblasts is an actinolitic hornblende, and this is also observed to replace pale brown aluminous hornblende. Little mineralogic evidence was found in these samples for pargasitic hornblendes of magmatic composition, although many samples display petrographic evidence of replacement by metamorphic hornblendes. Pallister and Hopson [1981] include several analyses of aluminous, postcumulus hornblendes that are likely magmatic in origin (Figure 8). We assume that the extensive moderate- to low-temperature hydrothermal alteration of the northern Samail ophiolite (see below) has caused such high-temperature hornblendes to be replaced by lower-temperature actinolitic bornblendes. The nature of the amphibole may reflect the phases being replaced; actinolitic hornblende, tremolite, and magnesio-hornblende can all be found together replacing clinopyroxene, olivine, and plagioclase, respectively.

The most abundant type of amphibole found in all three transects through the northern part of the ophiolite is actinolitic hornblende to magnesio-hornblende (Figure 8). This is present in almost all samples, and makes up as much as $25 \%$ of some heavily altered samples. These compositions are most characteristic of transitional greenschist- to amphibolite-facies metamorphism [Liou et al., 1974], and the equilibrium plagioclase at these conditions would be An25-An50 [Spew, 1980]

Much of the spread in amphibole compositions, for example in tetrahedral Si (Figure 8), may be observed in different amphiboles from the same sample. Actinolite and tremolite are more common at Shafan than in the other transects, compatible with ${ }^{18} \mathrm{O} /{ }^{16} \mathrm{O}$ evidence for low-temperature hydrotbermal alteration there (see below). Brown aluminous hornblende is a common mineral in the pegmatoidal gabbros in Wadi Rajmi all the way down to the Moho, compatible with the ${ }^{18} \mathrm{O} /{ }^{16} \mathrm{O}$ evidence for deep-seated high-temperature hydrothermal alteration there (see below). In other areas, both in the northern and southern parts of the ophiolite, brown aluminous hornblende is only common in the high-level gabbros or in trace amounts in the cumulate gabbros. The most Fe-rich amphiboles occur in high-level gabbros and the sheeted dike complex.

\section{Epidote Compositions}

Representative epidote compositions (Ps13 to Ps33) are provided in Table 8. Epidotes are observed as an accessory mineral in cumulate gabbros, as a minor phase in high-level gabbros, and as a major mineral in plagiogranites, diorites, and alteration zones. The Fe-poor epidotes and zoisites replace feldspar in the gabbros and plagiogranites, whereas the Fe-rich varieties occur as strongly zoned vein minerals typically associated with sulfides. These vein epidotes are characteristically normally zoned (i.e., with Fe-rich cores, Table 8, analyses 6 and 7). Host 
TABLE 7c. Hilti Amphibole Compositions

\begin{tabular}{|c|c|c|c|c|c|c|c|}
\hline & \multicolumn{7}{|c|}{ Analyses } \\
\hline & $\begin{array}{c}1 \\
81-202\end{array}$ & $\stackrel{2}{81-202}$ & $\begin{array}{c}3 \\
81-206\end{array}$ & $\begin{array}{c}4 \\
81-206\end{array}$ & $\begin{array}{c}5 \\
81-207\end{array}$ & $\begin{array}{c}6 \\
81-207\end{array}$ & $\begin{array}{c}7 \\
81-221\end{array}$ \\
\hline $\begin{array}{l}\mathrm{SiO}_{2} \\
\mathrm{TiO}_{2} \\
\mathrm{Al}_{2} \mathrm{O}_{3} \\
\mathrm{FeO}^{*} \\
\mathrm{MnO} \\
\mathrm{MgO} \\
\mathrm{CaO} \\
\mathrm{Na}_{2} \mathrm{O} \\
\mathrm{K}_{2} \mathrm{O} \\
\mathrm{Cl} \\
\mathrm{F} \\
\text { Total }\end{array}$ & $\begin{array}{r}56.14 \\
0.09 \\
1.94 \\
5.27 \\
0.17 \\
21.25 \\
12.72 \\
0.31 \\
0.01 \\
0.04 \\
0.00 \\
97.94\end{array}$ & $\begin{array}{r}50.94 \\
0.54 \\
6.27 \\
6.33 \\
0.18 \\
19.08 \\
12.72 \\
1.03 \\
0.05 \\
0.01 \\
0.00 \\
97.15\end{array}$ & $\begin{array}{r}47.60 \\
0.45 \\
10.42 \\
9.62 \\
0.16 \\
14.66 \\
12.39 \\
0.80 \\
0.04 \\
0.09 \\
0.09 \\
96.32\end{array}$ & $\begin{array}{r}50.51 \\
0.78 \\
8.25 \\
7.53 \\
0.19 \\
16.93 \\
12.30 \\
0.90 \\
0.05 \\
0.11 \\
0.13 \\
97.63\end{array}$ & $\begin{array}{r}56.13 \\
0.01 \\
0.76 \\
10.68 \\
0.10 \\
17.70 \\
13.31 \\
0.04 \\
0.00 \\
0.00 \\
0.00 \\
98.73\end{array}$ & $\begin{array}{r}51.22 \\
0.12 \\
5.49 \\
12.91 \\
0.30 \\
16.11 \\
9.88 \\
0.29 \\
0.04 \\
0.02 \\
0.00 \\
96.38\end{array}$ & $\begin{array}{r}52.96 \\
0.36 \\
1.60 \\
19.46 \\
0.22 \\
11.70 \\
10.80 \\
0.43 \\
0.05 \\
0.07 \\
0.03 \\
97.68\end{array}$ \\
\hline$-\mathrm{O}=\mathrm{Cl}, \mathrm{F}$ & 0.01 & 0.00 & 0.06 & 0.08 & 0.00 & 0.00 & 0.03 \\
\hline Total & 97.93 & 97.15 & 96.26 & 97.60 & 98.73 & 98.38 & 97.65 \\
\hline $\begin{array}{l}\mathrm{Si} \\
\mathrm{Al} \\
\text { Sum in } \mathrm{T}\end{array}$ & $\begin{array}{r}15 \mathrm{NK} \\
7.772 \\
0.228 \\
8.000\end{array}$ & $\begin{array}{r}15 \mathrm{NK} \\
7.191 \\
0.809 \\
8.000\end{array}$ & $\begin{array}{r}15 \mathrm{NK} \\
6.896 \\
1.104 \\
8.000\end{array}$ & $\begin{array}{c}13 \mathrm{CNK} \\
7.097 \\
0.903 \\
8.000\end{array}$ & $\begin{array}{c}\text { 13NCK } \\
7.895 \\
0.105 \\
8.000\end{array}$ & $\begin{array}{r}15 \mathrm{NK} \\
7.428 \\
0.572 \\
8.000\end{array}$ & $\begin{array}{c}\text { 13CNK } \\
7.734 \\
0.266 \\
8.000\end{array}$ \\
\hline $\begin{array}{l}\mathrm{Al} \\
\mathrm{Fe}^{3+} \\
\mathrm{Ti} \\
\mathbf{M g} \\
\mathrm{Fe}^{2+} \\
\mathrm{Mn} \\
\mathrm{Ca} \\
\mathrm{Sum} \text { in } \mathrm{C}\end{array}$ & $\begin{array}{l}0.089 \\
0.035 \\
0.009 \\
4.384 \\
0.482 \\
0.000 \\
0.000 \\
5.000\end{array}$ & $\begin{array}{l}0.235 \\
0.168 \\
0.057 \\
4.014 \\
0.525 \\
0.000 \\
0.000 \\
5.000\end{array}$ & $\begin{array}{l}0.677 \\
0.097 \\
0.049 \\
3.165 \\
1.012 \\
0.000 \\
0.000 \\
5.000\end{array}$ & $\begin{array}{l}0.465 \\
0.315 \\
0.082 \\
3.545 \\
0.570 \\
0.023 \\
0.000 \\
5.000\end{array}$ & $\begin{array}{l}0.021 \\
0.060 \\
0.001 \\
3.710 \\
1.196 \\
0.120 \\
0.000 \\
5.000\end{array}$ & $\begin{array}{l}0.367 \\
0.090 \\
0.013 \\
3.482 \\
1.048 \\
0.000 \\
0.000 \\
5.000\end{array}$ & $\begin{array}{l}0.010 \\
0.666 \\
0.040 \\
2.546 \\
1.711 \\
0.027 \\
0.000 \\
5.000\end{array}$ \\
\hline $\begin{array}{l}\mathrm{Fe}^{2+} \\
\mathrm{Mn} \\
\mathrm{Ca} \\
\mathrm{Na} \\
\text { Sum in } \mathrm{B}\end{array}$ & $\begin{array}{l}0.093 \\
0.020 \\
1.887 \\
0.000 \\
2.000\end{array}$ & $\begin{array}{l}0.054 \\
0.022 \\
1.924 \\
0.000 \\
2.000\end{array}$ & $\begin{array}{l}0.057 \\
0.020 \\
1.923 \\
0.000 \\
2.000\end{array}$ & $\begin{array}{l}0.000 \\
0.000 \\
1.852 \\
0.148 \\
2.000\end{array}$ & $\begin{array}{l}0.000 \\
0.000 \\
2.000 \\
0.000 \\
2.000\end{array}$ & $\begin{array}{l}0.428 \\
0.037 \\
1.535 \\
0.000 \\
2.000\end{array}$ & $\begin{array}{l}0.000 \\
0.000 \\
1.690 \\
0.122 \\
1.812\end{array}$ \\
\hline $\begin{array}{l}\mathrm{Ca} \\
\mathrm{Na} \\
\mathbf{K} \\
\text { Sum in } \mathbf{A}\end{array}$ & $\begin{array}{l}0.000 \\
0.083 \\
0.002 \\
0.085\end{array}$ & $\begin{array}{l}0.000 \\
0.282 \\
0.009 \\
0.291\end{array}$ & $\begin{array}{l}0.000 \\
0.225 \\
0.007 \\
0.232\end{array}$ & $\begin{array}{l}0.000 \\
0.097 \\
0.009 \\
0.106\end{array}$ & $\begin{array}{l}0.006 \\
0.011 \\
0.000 \\
0.017\end{array}$ & $\begin{array}{l}0.000 \\
0.082 \\
0.007 \\
0.089\end{array}$ & $\begin{array}{l}0.000 \\
0.000 \\
0.009 \\
0.009\end{array}$ \\
\hline $\begin{array}{l}\mathbf{C I} \\
\mathbf{F} \\
\end{array}$ & $\begin{array}{l}0.009 \\
0.000 \\
\end{array}$ & $\begin{array}{l}0.002 \\
0.000 \\
\end{array}$ & $\begin{array}{l}0.022 \\
0.041 \\
\end{array}$ & $\begin{array}{l}0.026 \\
0.058 \\
\end{array}$ & $\begin{array}{l}0.000 \\
0.000 \\
\end{array}$ & $\begin{array}{l}0.005 \\
0.000 \\
\end{array}$ & $\begin{array}{l}0.017 \\
0.014 \\
\end{array}$ \\
\hline
\end{tabular}

gabbro adjacent to an epidote-bearing vein usually contains epidote that is reversely zoned (i.e., with Fe-rich margins, Table 8 , analyses 4 and 5). In Wadi Shafan, two types of epidote were observed in the high-level gabbros: normal green pistacite and pink thullite (e.g. Table 8, analysis 8). This Mn-rich epidote was only observed as radial aggregates apparently associated with replacement of Mn-rich ilmenite by sphene. The aluminous epidote found sparsely in the cumulate gabbros is characteristic of lower-amphibolite grade metamorphism, transitional to greenschist [Marnyama et al., 1983].

\section{Chlorite and Smectite Compositions}

Representative chlorite and smectite compositions are provided in Table 9. The chlorites include Fe-rich (ripidolite, diabanite, pycnochlorite) and $\mathrm{Fe}$-poor compositions (penninite, chlinochlore). The more magnesian varieties are found in minor amounts in the layered gabbros. In the gabbros with only trace quantities of hydrous alteration minerals, small fractures contain talc where they cross olivine grains, amphibole where they cross pyroxene grains, and chlorite where they cross plagioclase grains. Clearly, these features indicate relatively low water/rock ratios and host mineral control of the vein mineralogy. The Fe-rich varieties of chlorite are typically found in larger veins and fractures, commonly associated with epidote. Brown to green finegrained smectite is fairty common as a late replacement of the mafic minerals.

\section{Prehnite and Zeolite Compositions}

Prehnite, thomsonite, and other calcic zeolites were locally observed as vein fillings and replacements of plagioclase in the northern Samail ophiolite, with prehnite in particular being ubiquitous throughout the cumulate sections of all three transects. Representative analyses are provided in Table 10. The ubiquitous occurrence of thomsonite and prehnite in the lower half of 

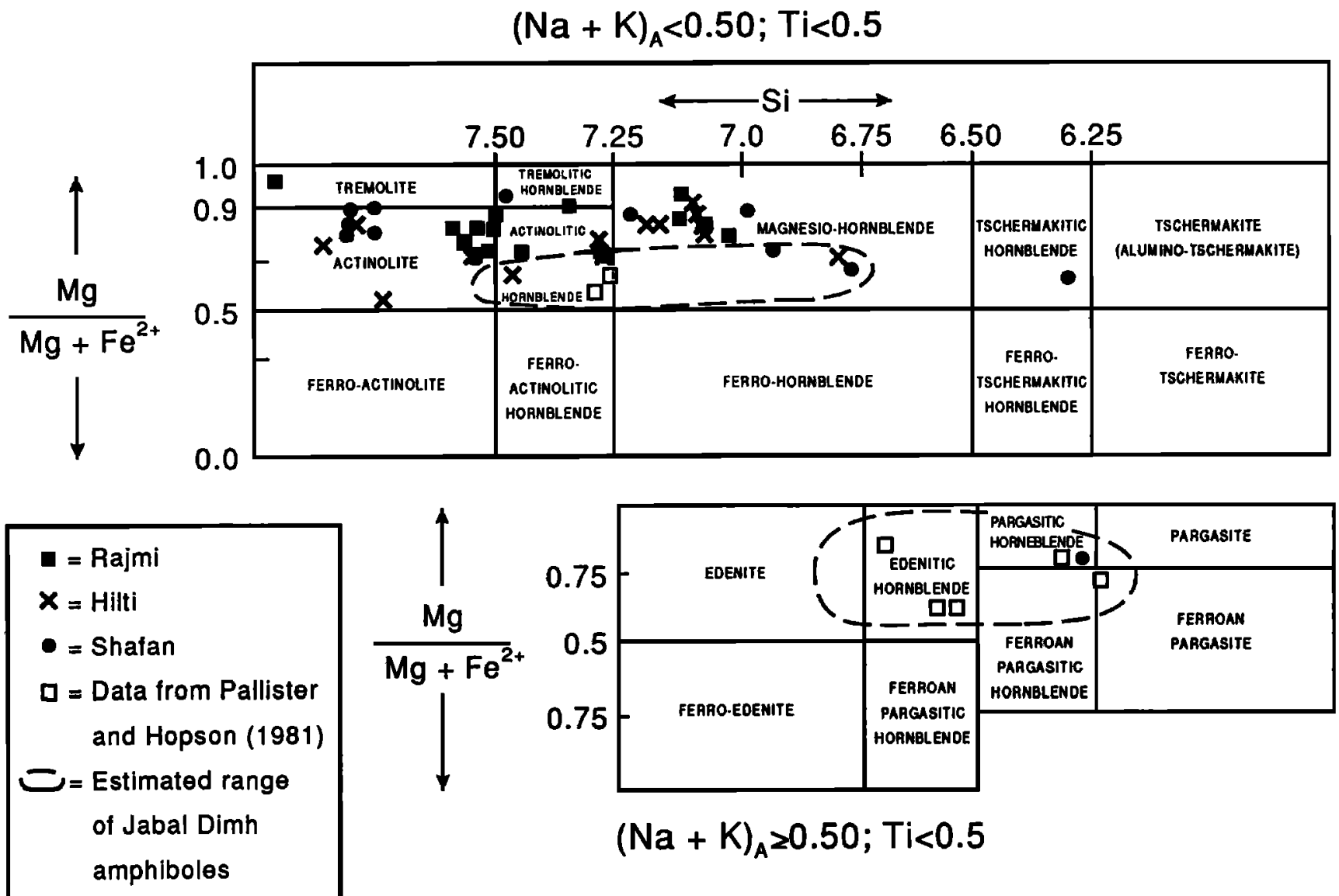

Fig. 8. Plot of amphibole compositions based on $\left[\mathrm{Mg} / \mathrm{Mg}+\left(\mathrm{Fc}^{+2}\right)\right]$ vs. tetrahedral Si, with nomenclature taken from Robinson et al. [1982]. Most samples from the present study have A site substitution of $\mathrm{Na}+\mathrm{K}$ less than 0.5 (top chart) while amphiboles from Jabal Dimh contain A site substitution $\geq 0.5$ (bottom chart). The substitution of $\mathrm{Na}+\mathrm{K}$ into the $\mathrm{A}$ site and value of $\mathrm{Fe}{ }^{+2}$ are dependent upon how the mineral formula is calculated from the microprobe analyses, as discussed in the text. Magnesiohomblendes are most characteristic as replacements of plagioclase, whereas actinolitic homblende is most characteristic as replacement of pyroxene. Tremolite and tremolitic hornblende are observed to replace olivine. This range of amphibole compositions is consistent with that described from Jabal Dimh by Pallister and Hopson [1981] (their analyses have been recalculated using our formulas) in the southern part of the ophiolite, except that the more aluminous brown magmatic homblende they describe from the cumulate gabbros is very rare in our samples. The amphiboles described in this study are skewed toward lower Al (and lower temperature) compositions.

the Wadi Hilti section suggests extensive low-temperature alteration and may be correlated with alteration of the ultramafic units and subsequent "rodingitization" of the felsic members. Prehnite is also found with epidote in the shallower portions of all three transects and is especially abundant near the plagiogranite intrusion in Wadi Shafan. Prehnite found as a vein mineral with epidote and sulfide typically contains significant amounts of FeO.

The maximum temperature at which prehnite is stable is about $400^{\circ} \mathrm{C}$ [Bird and Helgeson, 1981]. This places an upper limit on the temperatures of fluids responsible for the sulfide-epidoteprehnite assemblages in the high-level gabbros and sheeted dike complex. Obviously, significant quantities of seawater continued to circulate through the lower parts of the Wadi Hilti and Wadi Shafan sections even after these rocks had cooled down to $300^{\circ}$ $400^{\circ} \mathrm{C}$, compatible with the fact that the prehnite veins in the basal cumulates are always a late stage replacement feature. The prehnite veins crosscut earlier formed amphiboles and form networks through plagioclase. This in turn suggests that formation of most of the characteristic hydrothermal amphiboles was largely complete by the time temperatures reached the low values characteristic of prehnite formation.

\section{OXYGEN ISOTOPE GEOCHEMISTRY OF THE TRANSECTS}

\section{General Statement}

The ${ }^{18} \mathrm{O} /{ }^{16} \mathrm{O}$ data given in Tables $1,2,3$, and 4 are presented on graphs of $\delta^{18}$ O versus depth in Figures 9,10 , and 12 . Because we wish to compare these profiles with one another (and with other profiles from the southern part of the ophiolite) and because we are most concerned with the plutonic crustal sequence, it is useful to normalize the thickness of the gabbro portion of the section in each of the transects. Thus, irrespective of the actual stratigraphic thickness from the Moho to the base of the sheeted dike complex (SDC), we have plotted all of the ${ }^{18} \mathrm{O} /{ }^{16} \mathrm{O}$ data on Figures 9,10 , and 12, as if the gabbroic portions of the sections each had exactly the same thickness.

All of the northern Samail transects studied in the present work display significantly more ${ }^{18} \mathrm{O} /{ }^{16} \mathrm{O}$ heterogeneity than the $\delta^{18} \mathrm{O}$ values of +5.6 to +6.0 characteristic of MORB (Figures 9, 10, and 12). Also, as in the southern part of the ophiolite, the upper parts of the oceanic crustal sequences in the north tend to be 
TABLE 8. Epidote Compositions

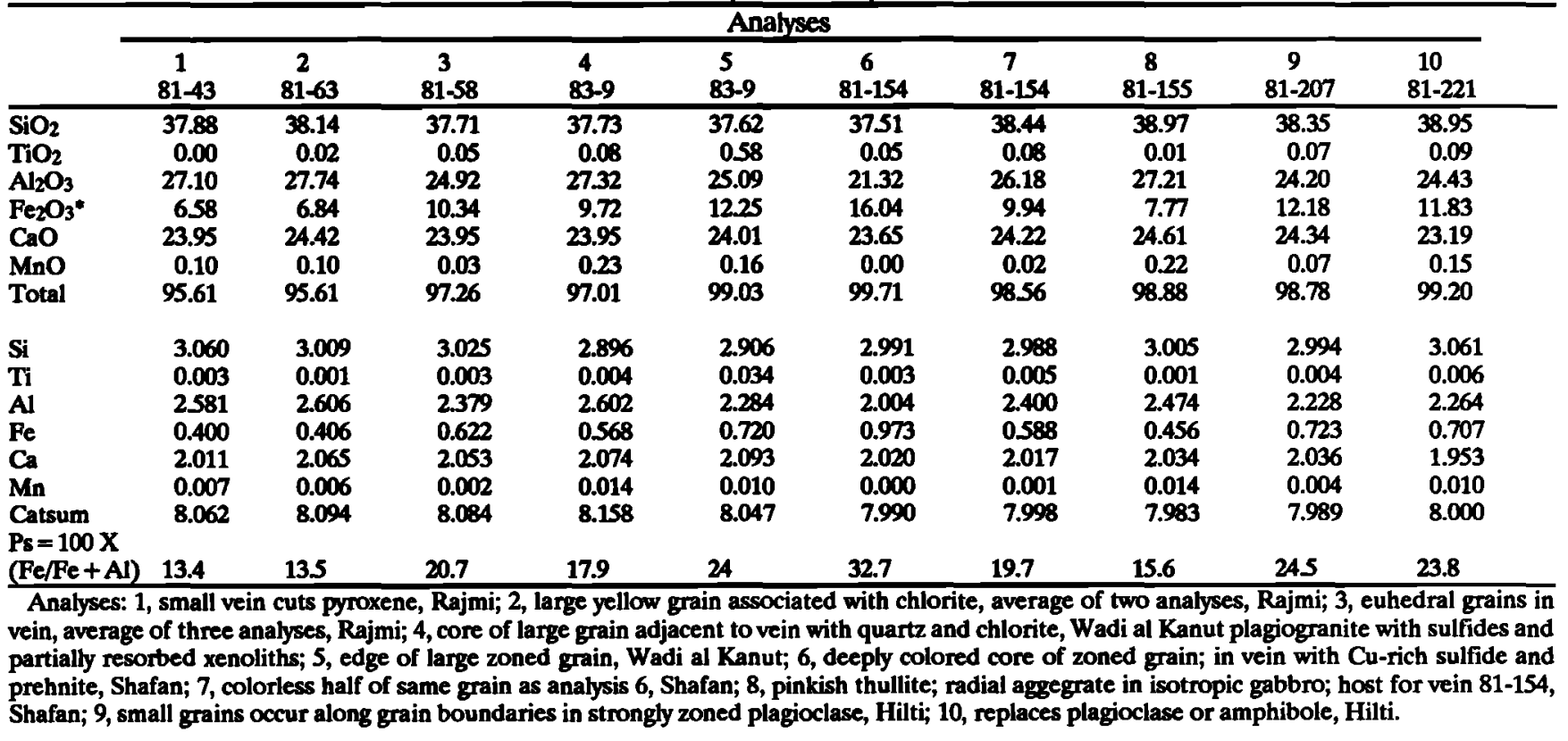

enriched in ${ }^{18} \mathrm{O}$ and the lower parts tend to be depleted in ${ }^{18} \mathrm{O}$. However, we shall demonstrate below that the transects in the north display considerable heterogeneity in ${ }^{18} \mathrm{O} /{ }^{16} \mathrm{O}$ relative to one another and to the Ibra transects in the south, mainly because (1) the northern transects were "selected" as being representative of extreme structural types of oceanic crust; (2) the sampled sections in the north are from a much broader area $(100 \mathrm{~km} \times 20$ $\mathrm{km}$ ) than the Ibra profiles in the south; (3) the northern part of the ophiolite is more heterogenous and more complex than the southern part; and (4) the northern part of the ophiolite contains significant volumes of crust formed in an off-axis environment, and those magmas may have had an initial $\delta^{18} \mathrm{O}$ different from MORB.

In the following discussion, the samples that are enriched in ${ }^{18} \mathrm{O}$ relative to MORB are assumed to have been either hydrothermally altered at relatively low temperatures with pristine Cretaceous seawater $\left(\delta^{18} \mathrm{O} \approx-0.5\right)$ or at higher temperatures with an ${ }^{18} \mathrm{O}$-enriched (i.e., exchanged) seawater. Alteration at about $250^{\circ} \mathrm{C}$ in the presence of $\mathrm{H}_{2} \mathrm{O}$ with a $\delta^{18} \mathrm{O}=-0.5$ will leave the $\delta^{18} \mathrm{O}$ value of MORB-type plagioclase unchanged at ap-

TABLE 9. Chlorite and Smectite Compositions

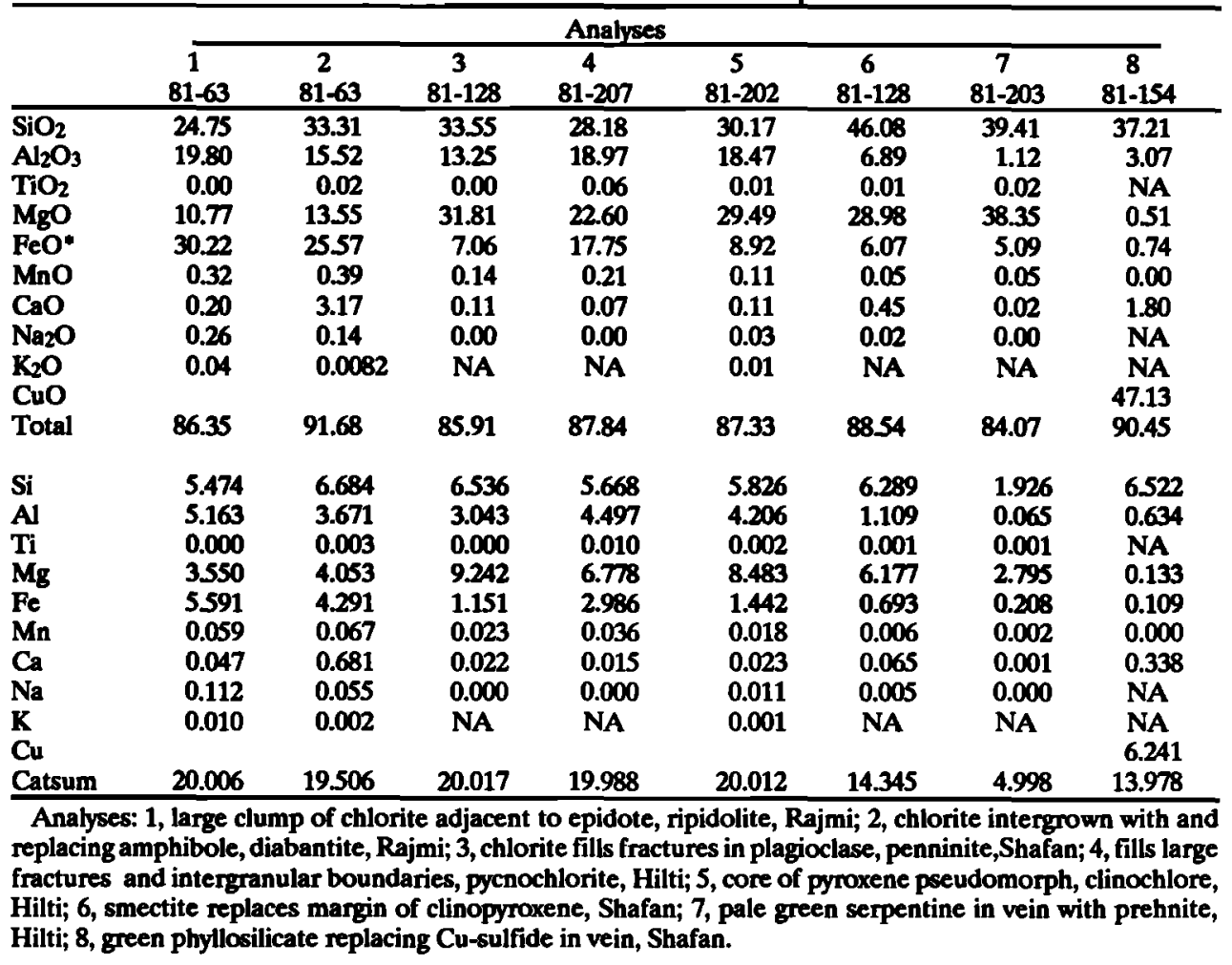


TABLE 10. Prehnite and Zeolite Compositions

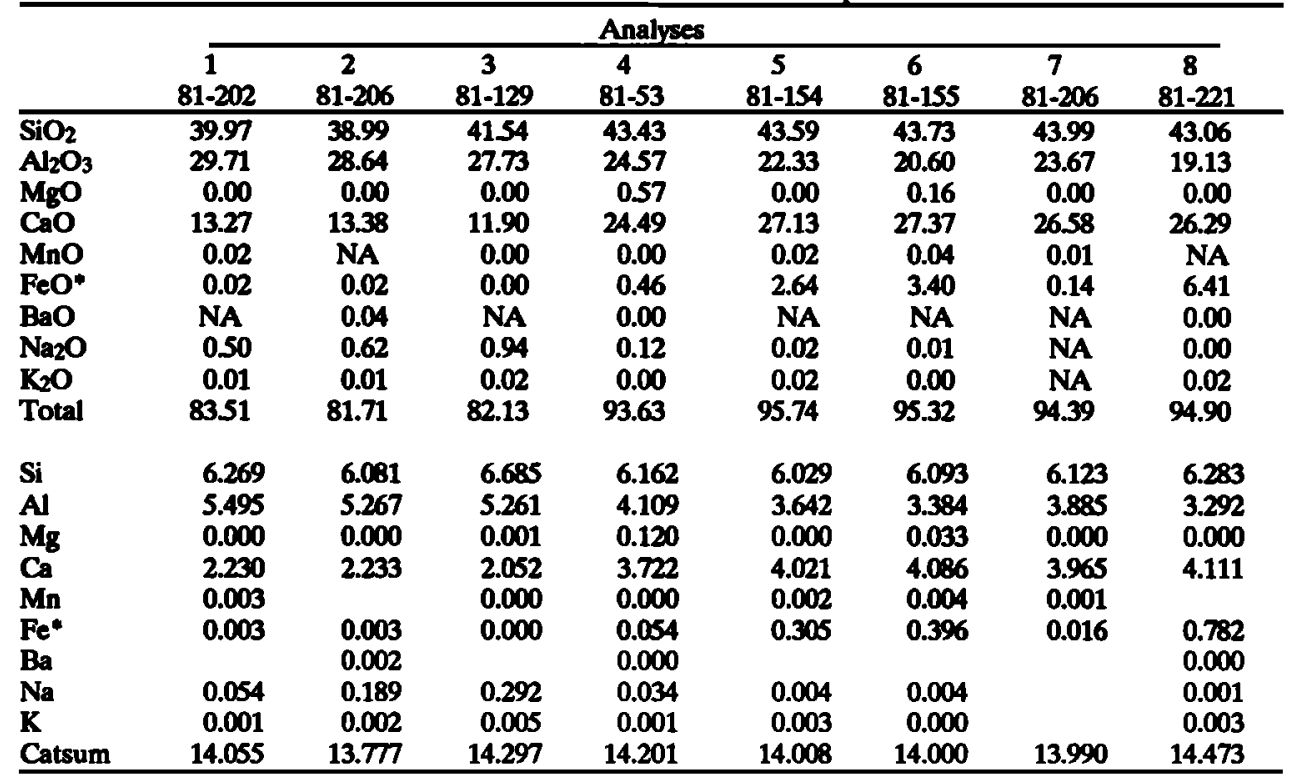

Analyses: 1, occurs as veins in plagioclase and radiating aggregrates, thomsonite, Hilti, 2, thomsonite replacing plagioclase; average of three, Hilti; 3, euhdral tabular vein mineral, Shafan; 4, prehnite, island in orthopyroxene, replacing plagioclase, Rajmi; 5 , blocky grain of prehnite in vein with sulfides and epidote, Shafan; 6, coarse prehnite replacing plagioclase adjacent to sulfide-epidote vein, Shafan; 7, late prehnite vein, Hilti; 8, prehnite in veins and replacing plagioclase, Hilti;

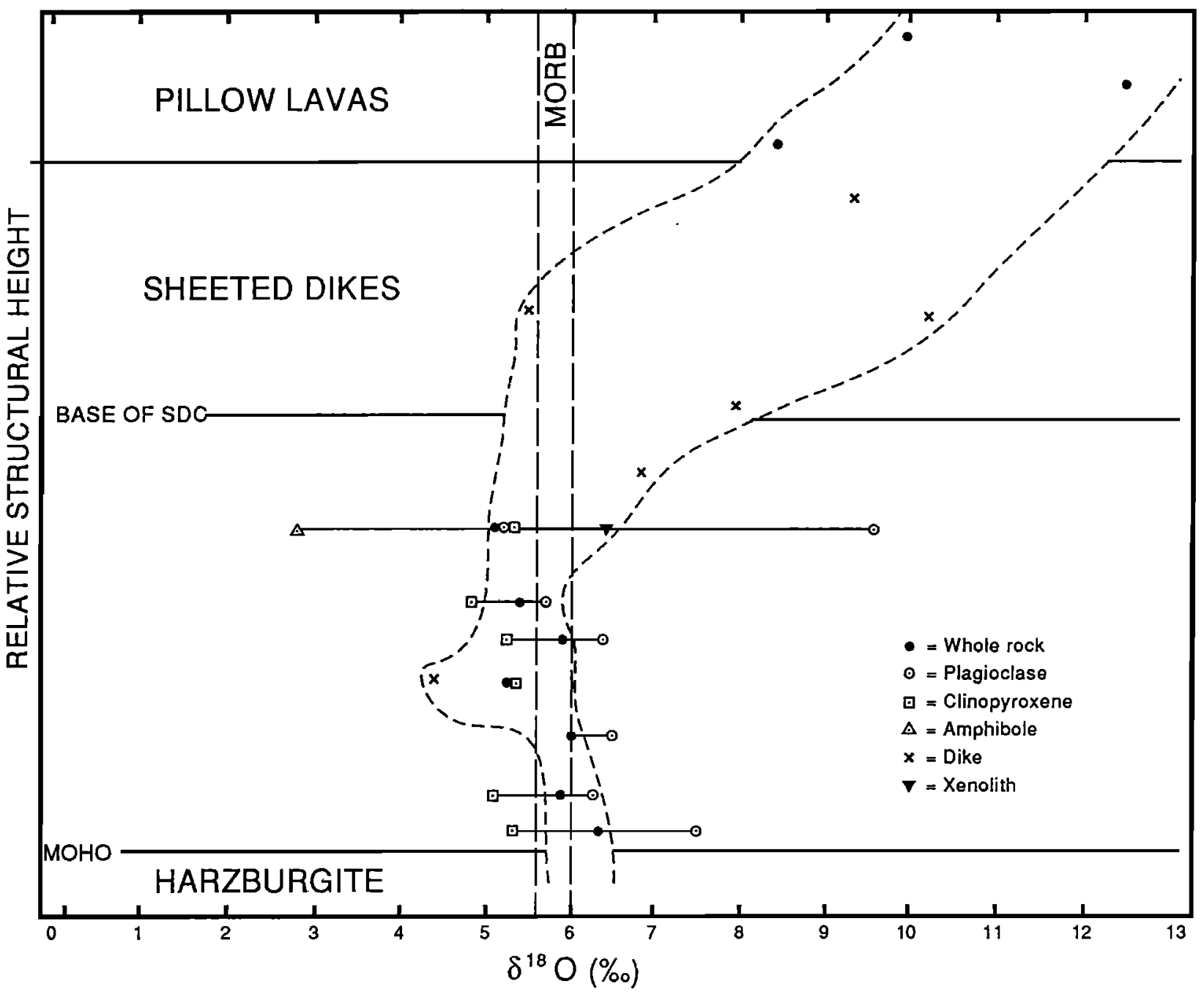

Fig. 9. Plot of $\delta^{18}$ O versus depth for the whole rock samples and mineral separates analyzed from the Wadi Hilti traverse (Table 2). The vertical axis in this diagram and in the subsequent diagrams is relative structural height in the oceanic crust section, with all of the gabbro sections normalized to the same thickness between the petrologic Moho and the base of the sheeted dike complex (SDC). The dashed curves enclose all of the whole-rock $\delta^{18} \mathrm{O}$ values in the transect. The horizontal lines connect coexisting mineral $\delta^{18} \mathrm{O}$ values. 


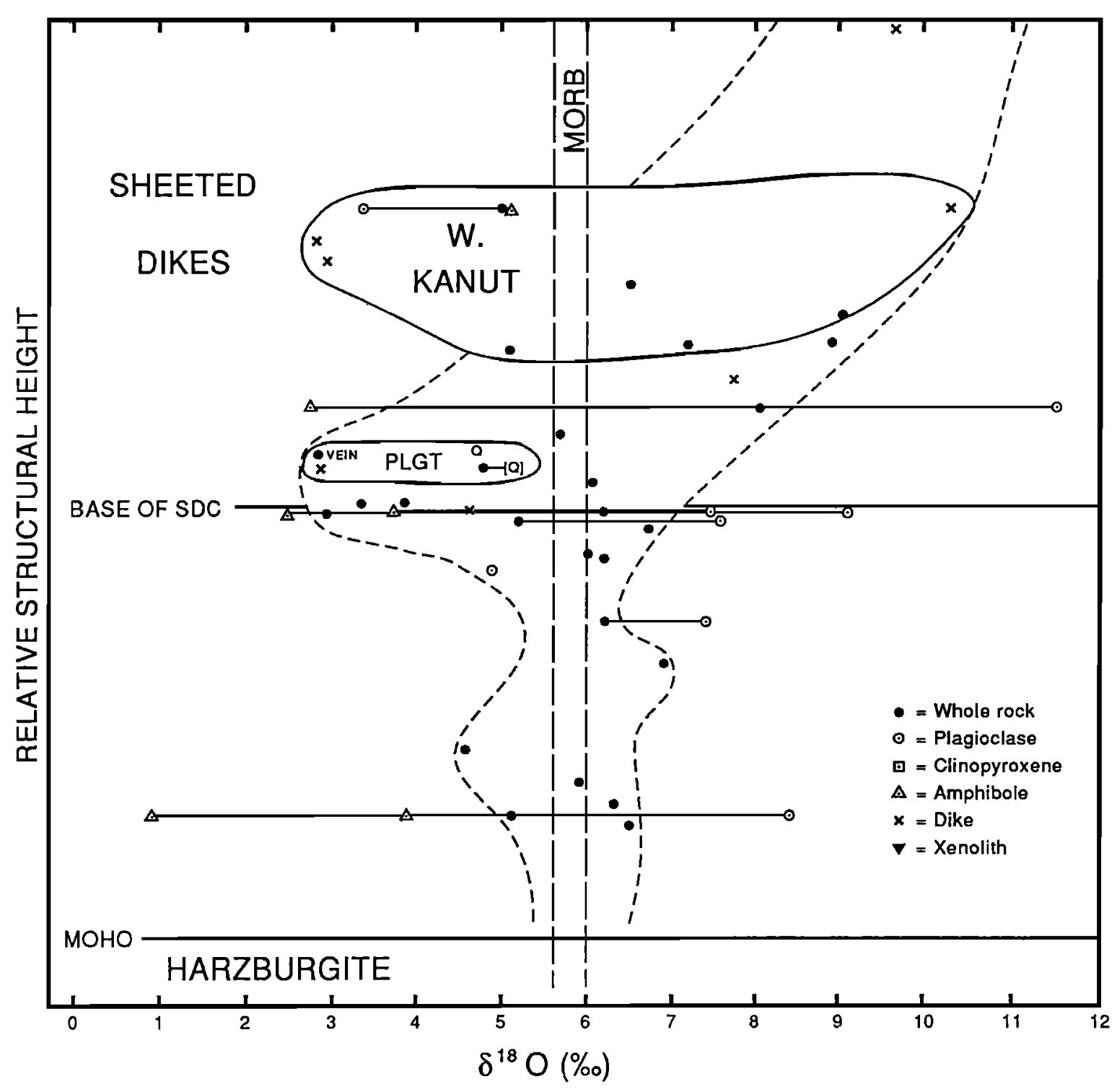

Fig. 10. Plot of $\delta^{18} \mathrm{O}$ versus depth for the whole rock samples and mineral separates analyzed from the composite Wadi Shafan-Wadi Kanut traverses (Tables 3 and 4). The vertical axis is normalized in that the distance from the Moho to the base of the SDC is identical to that given in Figure 9. The dashed curves enclose all of the whole rock $\delta^{18} \mathrm{O}$ values in the Wadi Shafan transect, with the whole rock $\delta^{18} \mathrm{O}$ values of the Shafan plagiogranite and the Kanut gabbro-diorite-plagiogranite body enclosed by the solid curves. $Q$, quartz.

proximately +6.0 [O'Neil and Taylor, 1967]. In other words, at this particular temperature, and excluding minor complications resulting from possible alteration to new hydrothermal minerals like prehnite, or to a more sodic plagioclase, the entire ocean could pass through and exchange with the rocks, leaving virtually no oxygen isotopic imprint on the feldspar! On the other hand, alteration at only a slightly lower temperature of $200^{\circ} \mathrm{C}$ will cause a readily discernible enrichment of more than $1 \%$, to about +8 ; at still lower temperatures, this ${ }^{18} \mathrm{O}$ enrichment of the feldspar becomes very striking, increasing to about +15 at $100^{\circ} \mathrm{C}$, and becoming much higher at still lower temperatures.

Above $300^{\circ} \mathrm{C}$, in the presence of pristine seawater, the $\delta^{18} \mathrm{O}$ of the plagioclase will certainly be lowered, to a value of about +2 at $400^{\circ} \mathrm{C}$, and down to as low as -2 at $800^{\circ} \mathrm{C}$. However, these ${ }^{18} \mathrm{O}$ depletions and all of the above quoted ${ }^{18} \mathrm{O}$ enrichments are extreme values, because they each require a pristine, unshifted $\delta^{18} \mathrm{O}$ for the seawater; hence, the prehistory of that particular packet of water requires either canceling exchange effects or an infinite water/rock ratio. If we apply the simple equation of Taylor [1977] for closed-system water-rock exchange and also assume a more reasonable prehistory with a water/rock ratio of about unity, we see much smaller ${ }^{18} \mathrm{O}$ shifts in the plagioclase $\left(\delta^{18} \mathrm{O}=+7\right.$ and +10 , respectively, instead of +8 and +15 ). Similarly, we get only +4 and +2 instead of +2 and -2 at $400^{\circ} \mathrm{C}$ and $800^{\circ} \mathrm{C}$. The respective ${ }^{18} \mathrm{O}$ shifts at each temperature are always in the same direction, but much smaller. The important thing is that starting with pristine ocean water, overall ${ }^{18} \mathrm{O}$ enrichments in the bulk oceanic crust require hydrothermal temperatures lower than $250^{\circ} \mathrm{C}$, and similarly, ${ }^{18} \mathrm{O}$ depletions in the bulk crust require temperatures higher than about $250^{\circ} \mathrm{C}$. Depending on the prehistory of each particular water packet, one can conceivably obtain almost any $\delta^{18} \mathrm{O}$ value for small quantities of exchanged ocean water and hence for any limited quantities of altered rocks with which this water exchanges. However, note that strongly ${ }^{18} \mathrm{O}$-enriched ocean waters that have exchanged only with basaltic and gabbroic rocks must have had a significant exchange history well 
above $350^{\circ} \mathrm{C}$, and those rocks will of course all exhibit a complementary downward ${ }^{18} \mathrm{O}$ shift. Major excursions in ${ }^{18} \mathrm{O}$ of large volumes of water independent of complementary shifts in large volumes of rock are forbidden by the requirements of mass balance.

\section{Wadi Hilti ${ }^{18} \mathrm{O}{ }^{16} \mathrm{O}$ ("Intact Oceanic Crust")}

The whole rock $\delta^{18} \mathrm{O}$ values of most of the Wadi Hilti gabbros are very uniform at +5.4 to +6.3 , just slightly outside the "normal" MORB range (Figure 9). Therefore, this is by far the most uniform section of layered gabbros yet studied in Oman. Also, most of the plagioclase-clinopyroxene $\Delta^{18}$ Ovalues are uniform at 1.0-1.2, which is typical of essentially unaltered plutonic gabbros throughout the world [Taylor, 1968; Taylor and Forester, 1979). The only exceptions are the two samples with extremely high- ${ }^{18} \mathrm{O}$ plagioclases, namely, the xenolith 81-208 and the lowermost layered gabbro 81-201. Clearly, these two relatively deep-seated plagioclases have been enriched in ${ }^{18} \mathrm{O}$ by subsolidus fluid-rock alteration, either as a result of exchange with relatively high- ${ }^{18} \mathrm{O}$ fluids or because exchange occurred (or continued to occur) down to temperatures lower than $200^{\circ} \mathrm{C}$. Similar effects are probably responsible for the slight ${ }^{18} \mathrm{O}$ enrichments in some of the other Hilti gabbros, as compared to the $\delta^{18} \mathrm{O}$ values observed by Gregory and Taylor [1981] in similar gabbros farther south.

Only three samples from Wadi Hilti are distinctly depleted in ${ }^{18} \mathrm{O}$, the layered gabbros 81-207 and 81-206 and the dike 81-204b. These samples constitute clear isotopic evidence that, at least locally, high-temperature aqueous fluids penetrated well down into the Wadi Hilti crust, particularly along the fracture occupied by the dike 81-204b. Because of the evidence quoted above for a late, low-temperature hydrothermal alteration at Hilti, either the low $\delta^{18} \mathrm{O}$ values of these particular samples were preserved for some unknown reason (e.g. vagaries of the hydrothermal "plumbing" and fracture systems), or they were originally even lower prior to this late stage alteration event.

The upper parts of the Wadi Hilti crust (sheeted dikes and pillow lavas) are strongly enriched in ${ }^{18} \mathrm{O}$ compared to MORB, typically up to $\delta^{18} \mathrm{O}$ values of +6.8 to +12.4 , similar to the values reported in the Ibra area by Gregory and Taylor [1981]. Also, as in the Ibra area, the pillow lavas have higher ${ }^{18} \mathrm{O}$ values than the sheeted dikes, and the major change from relatively low $\delta^{18} \mathrm{O}$ values to high $\delta^{18} \mathrm{O}$ values occurs fairly abruptly near the SDC -gabbro contact.

The Wadi Hilti ${ }^{18} \mathrm{O} /{ }^{16} \mathrm{O}$ variations nicely confirmed our expectations that this "intact oceanic crust" would display a relatively simple ${ }^{18} \mathrm{O} /{ }^{16} \mathrm{O}$ pattern. However, it is important to point out that a material-balance ${ }^{18} \mathrm{O} /{ }^{16} \mathrm{O}$ calculation for the entire Hilti section (Table 11) gives a $\delta^{18} \mathrm{O}$ slightly higher than MORB. This is a result of the fact that only minor ${ }^{18} \mathrm{O}$ depletions relative to MORB are observed in the Wadi Hilti layered gabbros, compared to the Wadi Kadir and Wadi Saq traverses of Gregory and Taylor [1981], where plagioclase and whole rock $\delta^{18} \mathrm{O}$ values of +3.6 to +4.5 are common in the layered gabbros. Also, in contrast to the relatively anhydrous Wadi Saq section, where the evidence for deep-seated, pervasive hydrothermal alteration comes mainly from the oxygen isotopic data, the Wadi Hilti gabbro samples all contain some hornblende and/or green acicular amphibole and commonly some chlorite, actinolite, and epidote as well; locally, they even contain prehnite and zeolites. In other words, there is clear petrographic evidence for deep hydrothermal activity at Wadi Hilti. Thus, in spite of the fairly uniform $\delta^{18} \mathrm{O}$ values, it is certain that the Hilti gabbro section was pervasively hydrother- mally altered; however, some of this alteration must have occurred either at lower water/rock ratios or at lower temperatures compared to the Wadi Saq gabbros.

Note that the lowest ${ }^{18} \mathrm{O}$ whole rock sample at Wadi Hilti $\left(\delta^{18} \mathrm{O}\right.$ $=+4.4$ ) is the late dike that cuts one of the deeper layered gabbro samples, 81-204. In this dike, the clinopyroxene is totally replaced by hornblende, whereas the pyraxene in the host gabbro is only partially replaced, and the $\delta^{18} \mathrm{O}$ of the plagioclase in the host gabbro is only depleted in ${ }^{18} \mathrm{O}$ by about $1 \%$ relative to MORB. It is common for the dike rocks in the ophiolite to be more ${ }^{18} \mathrm{O}$ depleted than the coarser-grained rocks that they intrude (Tables 1,2 , and 3). The more extreme effects in the dike, as compared to the host gabbro, seem to be readily explained by two factors: (1) the finer grain size of the dike makes it more susceptible to ${ }^{18} \mathrm{O} /{ }^{16} \mathrm{O}$ hydrothermal exchange [e.g., Gregory et al., 1989]; and (2) the fracture now occupied by the dike was likely an important conduit for the deeply circulating marine-hydrothermal fluids. Both the low $\delta^{18} \mathrm{O}$ value and the presence of hydrothermal hornblende imply that these must have been high-temperature fluids.

\section{Wadi Shafan-Kanut ${ }^{18} \mathrm{O} /{ }^{16} \mathrm{O}$ ("Complex Oceanic Crust")}

The ${ }^{18} \mathrm{O} /{ }^{16} \mathrm{O}$ pattern at Wadi Shafan-Kanut (Figure 10) is dramatically different from that of Wadi Hilti, or of any other published transect through the Samail ophiolite. These striking differences are mainly associated with the two large high-level intrusions, the Wadi Shafan plagiogranite and the Wadi Kanut composite wehrlite-gabbro-plagiogranite intrusion. Strong ${ }^{18} \mathrm{O}$ depletions are locally associated with both of these high-level intrusions, as would be expected if high-temperature hydrothermal convective systems formed locally around each magma chamber. The very low whole rock $\delta^{18} \mathrm{O}$ values of +2.9 and +3.0 around the Wadi Kanut intrusion are the lowest yet reported this high up in the sheeted dike complex. Also, the $\delta^{18} \mathrm{O}$ of the plagioclase $81-18(+3.4)$ is the lowest yet reported for plagioclase this high up in the SDC.

The Wadi Shafan plagiogranite body is intruded into a major shear zone, and it is possible that this zone of weakness controlled the emplacement of the plagiogranite. Striking ${ }^{18} \mathrm{O}$ depletions are generally present in the quartz veins, gabbros, and dikes within, and in the vicinity of, this shear zone (Table 3 and Figure 10). This is particularly true of those samples that are themselves strongly sheared, as well as those that are strongly epidotized (prefixes S and EP in Table 3). The locus of major ${ }^{18} \mathrm{O}$ depletions thus coincides with the contact zone of the plagiogranite body, with the base of the SDC, and with the shear zone, all of which are virtually coincident in Wadi Shafan. Inasmuch as the base of the SDC is not the locus of important ${ }^{18} \mathrm{O}$ depletions in any other studied transect through the Oman ophiolite, it is logical to conclude that some combination of the other two features must have provided the heat and permeability necessary to produce the observed ${ }^{18} \mathrm{O} /{ }^{16} \mathrm{O}$ effects.

The $\delta^{18} \mathrm{O}$ values from the Shafan-Kanut traverse thus nicely confirmed our a priori expectations that this transect would be isotopically complex, as well as our expectation that the principal complexities would be associated with the two large high-level intrusions and/or with the shear zone. Another interesting feature of the Wadi Shafan-Kanut traverse is that the layered gabbros are slightly enriched in ${ }^{18} \mathrm{O}$, with seven samples having whole rock $\delta^{18} \mathrm{O}=+6.2$ to +6.9 . These ${ }^{18} \mathrm{O}$ enrichments are even more striking than those in the Wadi Hilti cumulates, and they are in marked contrast with the Wadi Rajmi plutonic sections (see 
below), as well as with the Ibra sections in the southern part of the ophiolite, where essentially none of the layered gabbros bas a $\delta^{18} \mathrm{O}$ higher than +6.0 . The only notable exceptions are samples near the Moho with anomalously ${ }^{18} \mathrm{O}$-enriched plagioclase (see the discussion of this phenomenon below). It is logical to ascribe this overall slight ${ }^{18} \mathrm{O}$ enrichment of the Wadi Shafan layered gabbros to the superimposed effects of alteration in the distal, lower-temperature portions of the convective hydrothermal systems associated with the large, late stage intrusions that characterize the upper levels of this transect; fluid access to these depths would be enhanced by the numerous fractures and shear zones. This interpretation is compatible with the abundant prehnite in these rocks (Table 3), as well as with the extremely ${ }^{18} \mathrm{O}$-rich calcite $(+24.7)$ in sample 81-140. Small amounts of very low-temperature fluids $\left(<50^{\circ} \mathrm{C}\right)$ obviously passed through these rocks at a late stage in their cooling history.

Three samples of quartz were analyzed from the contact zone of the Wadi Shafan plagiogranite. For hydrothermal quartz, these $\delta^{18} \mathrm{O}$ values $(+4.8$ to +7.3$)$ are very low, and they require deposition from relatively ${ }^{18} \mathrm{O}$-depleted fluids (e.g., even at temperatures of $400^{\circ}-500^{\circ} \mathrm{C}$, the $\delta^{18} \mathrm{O}$ values of the coexisting water would be -0.4 to +4.1 using the quartz- $\mathrm{H}_{2} \mathrm{O}$ geothermometer used by Taylor [1974]. Lower-temperature deposition would require a considerably more ${ }^{18} \mathrm{O}$-depleted hydrothermal fluid than this.

A plausible interpretation of the Wadi Shafan-Kanut ${ }^{18} \mathrm{O} /{ }^{16} \mathrm{O}$ data might be as follows: (1) An original oceanic crustal section, which, except for its thickness, may have been similar to the sections in the Ibra and Hilti areas, was formed at a spreading center and hydrothermally altered in the "normal" way (i.e., with overall ${ }^{18} \mathrm{O}$ enrichments above the base of the SDC and overall ${ }^{18} \mathrm{O}$ depletions below it). (2) Subsequent formation of a major shear zone controlled the emplacement of a large plagiogranite body and localized the high-temperature hydrothermal activity at the base of the SDC. (3) Spreading away from this central axis was followed by high-level emplacement of off-axis composite intrusions, typified by the Wadi Kanut body. These local, highlevel magma chambers each established moderate-sized hydrothermal systems. These convective systems caused lowtemperature (i.e., higher ${ }^{18} \mathrm{O}$ and prehnite) alteration of the originally lower ${ }^{18} \mathrm{O}$ layered gabbros distant from and beneath these intrusions, but produced a high-temperature (lower- ${ }^{18} \mathrm{O}$, amphibole plus epidote) alteration just above, and in the immediate vicinity of, each high-level magma chamber.

The data from the Wadi Kanut intrusion are important because they show that these composite wehrlite-gabbro-plagiogranite intrusions, which are surely a late stage, off-axis phenomenon, can by themselves produce impressive, albeit local, zones of ${ }^{18} \mathrm{O}$ depletion. Their later stage ${ }^{18} \mathrm{O} /{ }^{16} \mathrm{O}$ effects are superimposed upon the original hydrothermal effects produced at the spreading axis. Locally, these composite intrusions are also abundant in deeper parts of the crustal section, in the layered gabbros (Figure 11). Except for some caution in assuming that the permeabilities of the layered gabbros would be as high as in the sheeted dikes, we can therefore readily infer that each of these deeper intrusions will establish its own hydrothermal system. A particularly com-

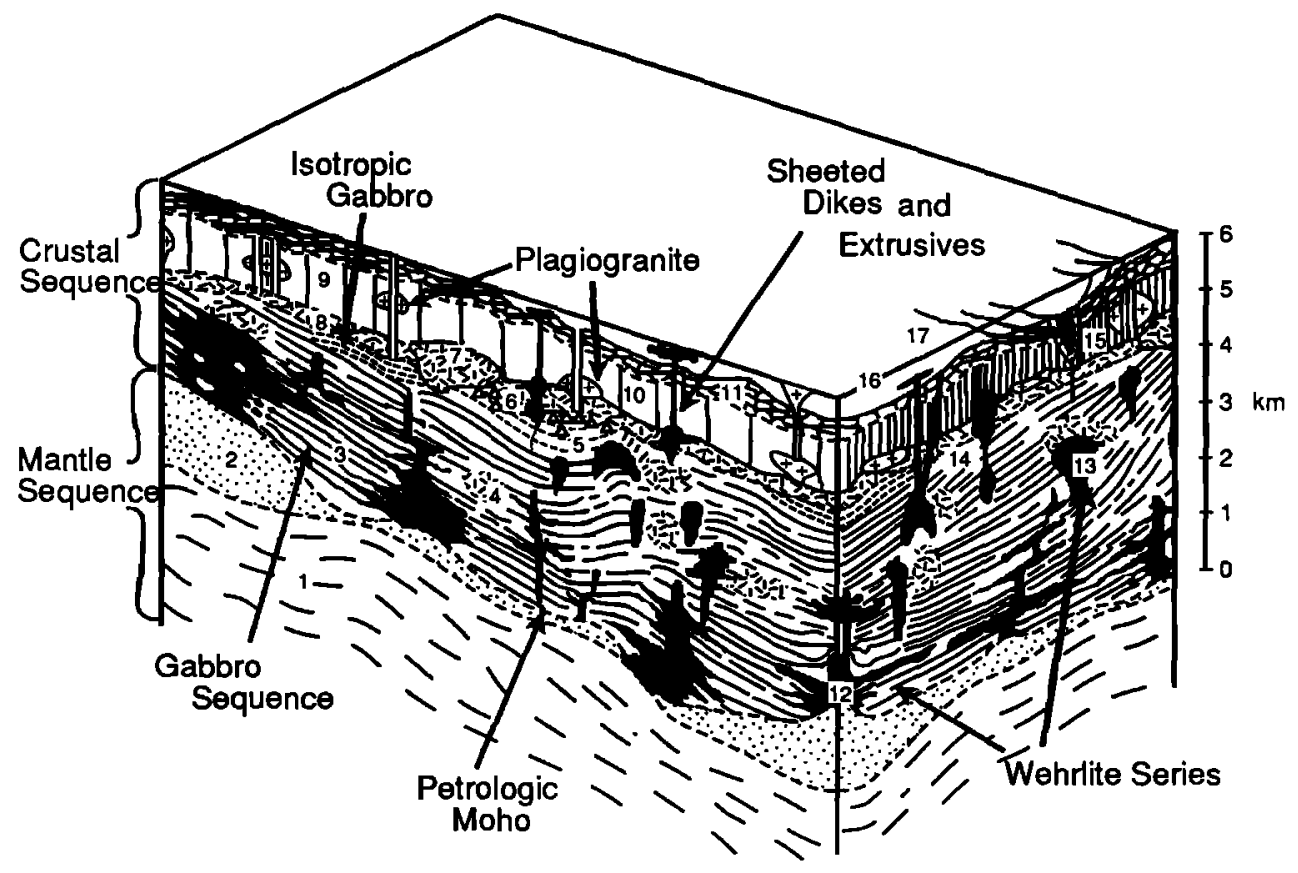

Fig. 11. Generalized block diagram taken from the work of Juteau et al. [1988a], summarizing their geologic model of the same part of the Samail Ophiolite studied in the present work. They divide the oceanic crustal section into two main magmatic series: (1) the primary crustal sequence was formed at the spreading axis from long-lived, elongate, periodically replenished magma chambers; and (2) the wehrlite series was intruded at a later stage as numerous thick laccolithic sills into the barely consolidated, still hot layered gabbros (these are commonly ductilely deformed). In the upper part of the oceanic crust these wehrlite intrusions are commonly fault-controlled and differentiated to gabbro, diorite, and plagiogranite. The numbers are keyed to lithologic units, as follows: Mantle sequence: (1) harzburgite and (2) impregnated residual dunites. Primary crustal sequence: (3) layered gabbro sequence; (4) recrystallized isotropic gabbros; (5) planar-laminated gabbro norites; (6) magmatic breccias; (7) intrusive isotropic gabbros; (8) high level isotropic gabbros; (9) sheeted dike complex; (10) plagiogranites; (11) lower extrusive lavas. Wehrlite series: (12) dunite-wehrlite laccoliths and sills, locally layered; (13) wehrlitic intrusive bodies; (14) picritic dikes; (15) differentiated intrusive bodies (wehrlites, gabbros, plagiogranites, and swarms of diabase and picrite sills and dikes); (16) upper extrusive lavas; and (17) clinopyroxene-rich and picrite basalts. 
pelling visual presentation of the scale of this phenomenon, as it relates to the northern Samail ophiolite, is given by Juteau et al. [1988a] (their Figure 23 is reproduced here as our Figure 11). One should imagine that as the oceanic crust migrates laterally away from the spreading aris, convective hydrothermal systems will exist for a significant length of time around each one of the solid black bodies displayed on the block diagram of Figure 11.

\section{Wadi Rajmi ${ }^{18} \mathrm{O}^{16} \mathrm{O}$ ("Fossil Transform")}

The combined Rajmi North and Rajmi South ${ }^{18} \mathrm{O} /{ }^{16} \mathrm{O}$ profile is shown in Figure 12. As might have been expected from the absence of any large, late-stage, high-level intrusions in the SDC and pillow lavas at Rajmi, the upper part of the profile is more like that of Wadi Hilti than that of Wadi Shafan-Kanut. However, the lower part of the Rajmi profile beneath the SDC is dramatically different from both Hilti and Shafan in displaying an astonishingly large zone of ${ }^{18} \mathrm{O}$ depletion. The whole rock $\delta^{18} \mathrm{O}$ values locally go down to values lower than +2 , and samples with $\delta^{18} \mathrm{O}$ lower than MORB are found throughout the entire section of layered gabbro, right down to the Moho. This enormous zone of ${ }^{18} \mathrm{O}$ depleted gabbros is much thicker, and overall much lower in ${ }^{18} \mathrm{O}$, than any other section through the Samail ophiolite, including all of the sections studied in the southern part of the ophiolite by Gregory and Taylor [1981; also unpublished data, 1992]. The data in Figure 12 therefore nicely confirm our expectations that whether the Wadi Rajmi area is a "fossil transform," an overlapping spreading center (OSC), or whatever, this zone of highly deformed and fractured rocks was obviously a high-permeability zone that was hydrothermally altered at high temperatures by large volumes of seawater.

Although moderate to strong ${ }^{18} \mathrm{O}$ depletions are ubiquitous throughout the section of layered gabbros at Wadi Rajmi, there are also some very clear structural and lithologic controls on these ${ }^{18} \mathrm{O} /{ }^{16} \mathrm{O}$ effects. All of the samples of gabbroic pegmatite listed in Table 1 are labeled PEG on Figure 12; note that a great preponderance of the PEG samples plot well to the left of the

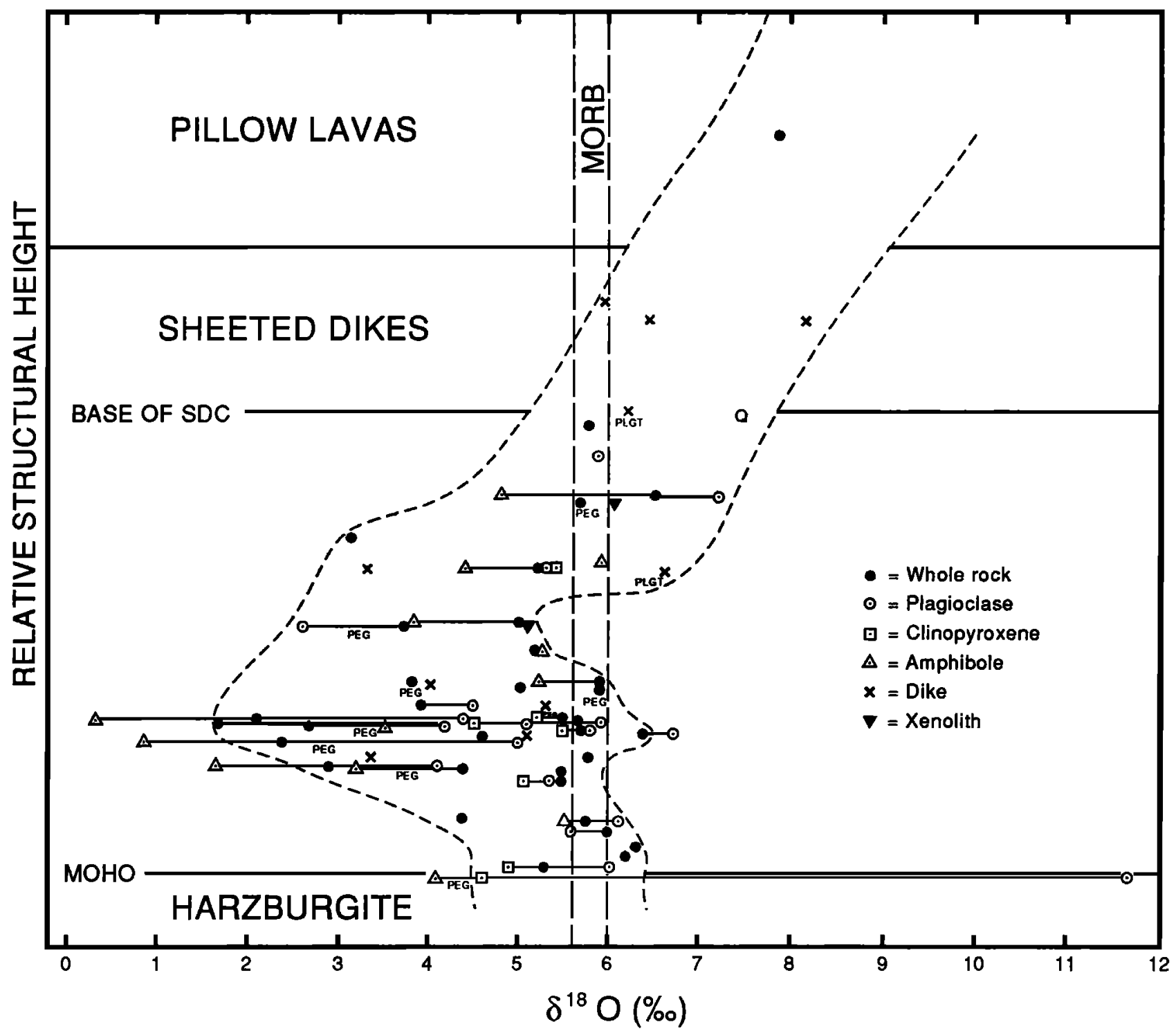

Fig. 12. Plot of $\delta^{18} \mathrm{O}$ versus depth for the mineral separates and whole rock samples from the two Wadi Rajmi traverses (Table 1). The vertical distance between the Moho and the base of the SDC is normalized to be identical to those given in Figures 9 and 10. The dashed curves enclose all of the whole rock $\delta^{18} \mathrm{O}$ values in the transect. PEG, gabbro pegmatite; PLGT, plagiogranite. 
MORB $\delta^{18} \mathrm{O}$ values, indicating that one major set of low- ${ }^{18} \mathrm{O}$ samples at Wadi Rajmi is made up of gabbroic pegmatite. Of the nine analyzed gabbro pegmatite samples, only two have $\delta^{18} \mathrm{O}$ as high as MORB, and several have whole-rock $\delta^{18} \mathrm{O}<+4$.

Another set of samples from Wadi Rajmi that tends to be strongly ${ }^{18} \mathrm{O}$-depleted is the group of abundant finer-grained dikes that cut the deformed layered gabbros (as well as the gabbro pegmatites) well down into the cumulate section. Five samples of these dikes have $\delta^{18} \mathrm{O}=+3.3$ to +5.3 (Table 1 and Figure 11). These low- ${ }^{18} \mathrm{O}$ dikes also all contain hydrous mineral assemblages indicative of hydrothermal metamorphism, and are analogous to Hilti sample 81-204b discussed above.

The final correlation with ${ }^{18} \mathrm{O} /{ }^{16} \mathrm{O}$ that is discernible from the data of Figure 12 is that that the extremely deformed and sheared samples tend to be associated with the most intense ${ }^{18} \mathrm{O}$ depletions. This is most obvious at locality 15 , where all of the rocks, including a hornblende-plagioclase pegmatite, are heavily sheared; these rocts display the lowest $\delta^{18} \mathrm{O}$ values yet found anywhere in the Samail ophiolite $(+1.7$ to +2.7$)$. Again, this kind of phenomenon is analogous to features observed in other transects (e.g., Wadi Shafan).

We also observe ${ }^{18} \mathrm{O}$ depletions in the host gabbros from those outcrops that contain low- ${ }^{18} \mathrm{O}$ gabbro pegmatites, $10{ }_{-}{ }^{18} \mathrm{O}$ dikes, or low- ${ }^{18} \mathrm{O}$ hydrothermal metamorphism associated with strong shearing and deformation. It is logical to conclude that abundant conduits for these high-temperature hydrothermal fluids were provided by the fractures now occupied by the pegmatite bodies and the late stage dikes, as well as the fractures that were probably opened and reopened during the intense shearing and deformation that characterize the Wadi Rajmi cumulate section. It is also plausible that the great abundance and complexity of deep, wehrlite-gabbro intrusions in this area [Reuber, 1988] is in a large degree attributable to the zones of structural weakness (e.g. "pull-aparts") provided by this intense shearing. Together with the gabbro pegmatites and dikes, these intrusions act as individual "heat engines" whose combined effects add to the high-temperature hydrothermal ${ }^{18} \mathrm{O}$ depletions originally produced at the spreading axis [Gregory and Taylor, 1981]. The combination of all of these phenomena produced the intense hydrothermal ${ }^{18} \mathrm{O}$ depletion that characterizes the lower level of the oceanic crust at Wadi Rajmi (e.g., see Figures 11 and 12).

The Wadi Rajmi area displays a number of structural, magmatic, and hydrothermal characteristics that are not at all typical of most other transects through the Samail ophiolite. For example, the Rajmi plutonic section contains abundant orthopyroxene, a feature that has so far been documented in only one other area in the ophiolite, at Wadi Hamiliyah, which Juteau et al. $[1988 a, b]$ believe was located at the southern tip of a spreading cell. The Wadi Hamiliyah area also exhibits petrographic evidence for abundant and pervasive hydrothermal alteration essentially down to the Moho, virtually identical to the relationships we have described at Rajmi [Nehlig and Juteau, 1988]. Although no ${ }^{18} \mathrm{O} /{ }^{16} \mathrm{O}$ data have yet been gathered from Wadi Hamiliyah, we predict that future ${ }^{18} \mathrm{O} /{ }^{16} \mathrm{O}$ studies of that area ought to be similar to our studies in the Rajmi area.

Although not as abundant as at Wadi Shafan, prehnite is locally present throughout the lower parts of the Wadi Rajmi section, probably to a greater degree than at Wadi Hilti. Therefore, judging by what seems to have happened at both Hilti and Shafan, we might infer a similar high- ${ }^{18} \mathrm{O}$ "overprint" of the Rajmi area. If so, this would imply that most of the Rajmi whole-rock samples and feldspars (Table 1 and Figure 12) were at one time even lower in ${ }^{18} \mathrm{O}$, prior to this late stage prehnitization. Some indica- tion of how low in ${ }^{18} \mathrm{O}$ these rocks might have been at one time is indicated by the spread of very low $\delta^{18} O$ values in the amphiboles (see Figure 15 below), because amphibole is much more resistant to the late, low-temperature overprint than is plagioclase. Note that the green secondary amphibole (actinolitic) is, in general, very low in ${ }^{18} \mathrm{O}$ compared to the primary-appearing brown hornblende, even where the latter is present in one of the laterstage intrusions (e.g., DIG sample 81-100, Table 1).

The abundance of low- ${ }^{18} \mathrm{O}$ gabbroic pegmatite in the Wadi Rajmi area is particularly informative with respect to another problem. Recall that in the Ibra area there is clear evidence for an extremely high-temperature $\left(>500^{\circ} \mathrm{C}\right)$ hydrothermal alteration event, based on the widespread occurrence of $10 w-{ }^{18} \mathrm{O}$, essentially anhydrous gabbro samples with reversed plagioclasepyrarene ${ }^{18} \mathrm{O} /{ }^{16} \mathrm{O}$ fractionations [Gregory and Taylor, 1981; Taylor, 1986]; however, such a conclusion is less certain in the north, because the samples in the north are full of hydrous minerals. However, no credible model of the formation of the gabbro pegmatites would suggest a temperature lower than about $600^{\circ}-700^{\circ} \mathrm{C}$, regardless of whether these pegmatites are magmatic or metamorphic in origin. In addition, the pegmatitic textures require $\mathrm{H}_{2} \mathrm{O}$-rich conditions [e.g., Jahns and Bumhan, 1969]. Thus, the strong linkage between the ${ }^{18} \mathrm{O}$ depletions and the development of gabbro pegmatite (Figure 12 and Table 1) suggests that very high-temperature hydrothermal activity at significant water/rock ratios also occurred in the layered gabbros of the northern Samail ophiolite, in spite of this event being partially obscured by the subsequent overprinting by moderate- to lowtemperature bydrothermal activity.

Only very limited ${ }^{18} \mathrm{O}$ enrichment is shown by the sheeted dikes and a single pillow lava from the Wadi Rajmi profile. In fact, the basalt sample 81-79 exhibits the lowest $\delta^{18} \mathrm{O}$ of any extrusive sample in the Samail ophiolite, if we exclude those samples that have been subjected to special circumstances of hydrothermal alteration, such as the samples from the stockwork vein system in the Lasail ore deposit (Table 4). This sample 81-79 is also from the axis sequence (e.g., Geotimes unit); these were hydrothermally metamorphosed at higher temperatures (greenschist versus zeolite facies) than the samples from the upper part of the off-axis sequence (e.g., the Alley unit); the latter unit has supplied most of the extremely high-18 $\mathrm{O}$ pillow lava samples analyzed to date (e.g., $\delta^{18} \mathrm{O}=+12$; Wadi Jizi [Gregory and Taylor, 1981], Table 4), and this may have led to an overestimate of the degree of ${ }^{18} \mathrm{O}$ enrichment of the entire section of pillow lavas (see the discussion below and Table 11).

\section{Comparison of the $\delta^{18}$ O-Depth Profiles}

On Figures 13 and 14 we compare the normalized ${ }^{18} \mathrm{O}$-depth profiles from this study with a similarly normalized profile obtained using the data of Gregory and Taylor [1981] from the Ibra area in the southern part of the Oman ophiolite. These comparisons are made on two separate diagrams, in order to obtain sufficient clarity in the presentation. As a further aid in comparing all these data, Table 11 has been prepared to summarize various kinds of material balance ${ }^{18} \mathrm{O} /{ }^{16} \mathrm{O}$ features of the different profiles, as well as that of the bulk ophiolite.

The Ibra and Rajmi transects are the two profiles that display the most extreme ${ }^{18} \mathrm{O}$ depletions within the gabbro portions of the Samail ophiolite. Both profiles are essentially coincident at the Moho, and in both profiles the average $\delta^{18} \mathrm{O}$ value of the gabbro section is distinctly lower than MORB (Table 11). The two profiles differ mainly in the following respects: (1) The highly sheared and diked Wadi Rajmi gabbro section is overall much 


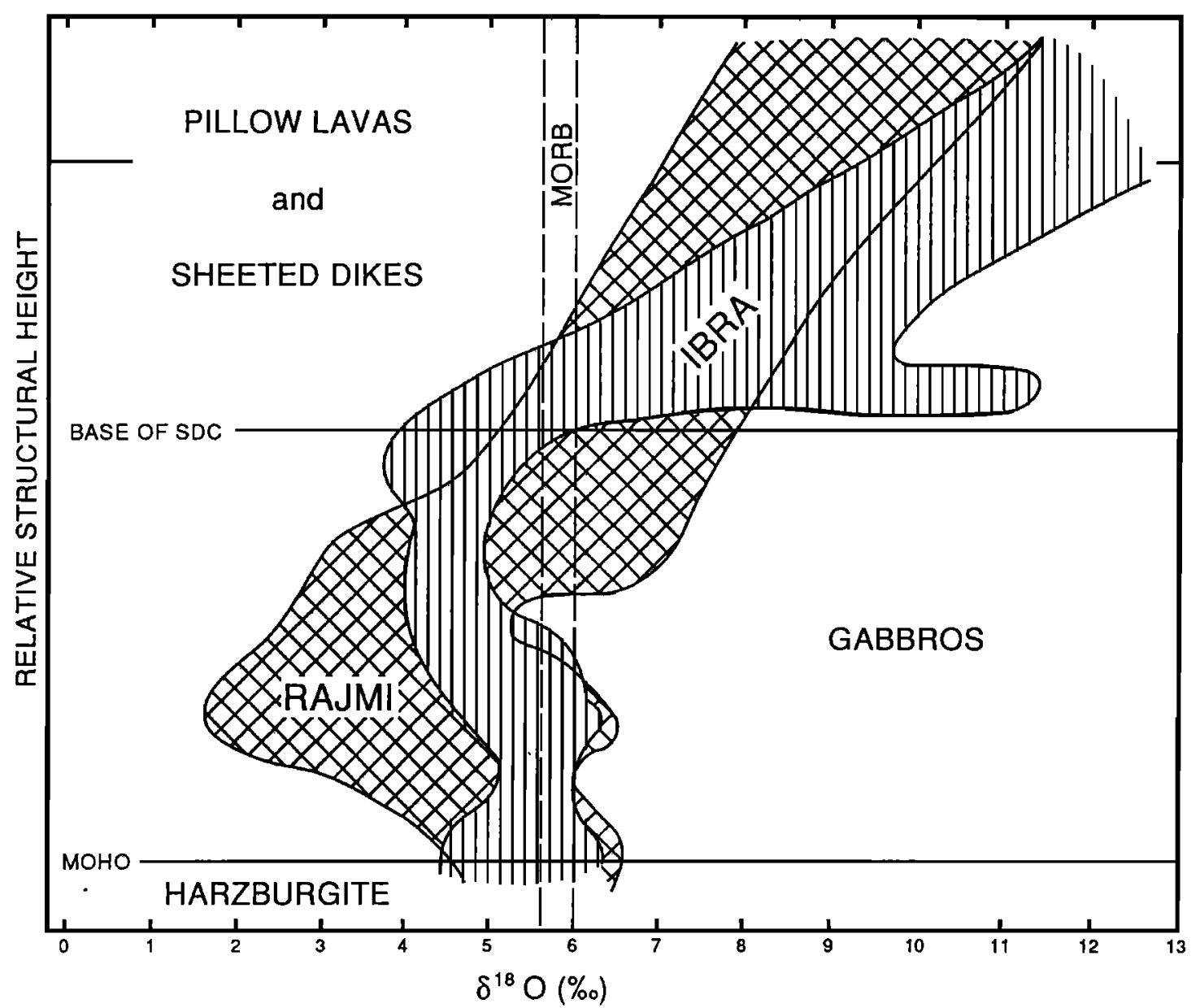

Fig. 13. Comparison of the $\delta^{18} \mathrm{O}$ versus depth profile of the Wadi Rajmi profile from Figure 12 of the present work with the composite Wadi Saq and Wadi Kadir traverses from the Ibra area of the southem Samail ophiolite [after Gregory and Taylor, 1981]. These are both normalized to the same scale of distance between the Moho and the base of the SDC.

lower in ${ }^{18} \mathrm{O}$ than the Ibra gabbros $\left(\delta^{18} \mathrm{O}=+4.86 \mathrm{vs.}+5.34\right.$, Table 11). (2) The ${ }^{18} \mathrm{O}$ depletions at Rajmi mainly occur in the lower part of the gabbro section, whereas at Ibra they mainly occur in the upper half of the section (Figure 13). (3) Above the SDC-gabbro contact, the section at Ibra is distinctly higher in ${ }^{18} \mathrm{O}$ than at Rajmi; this is true of both the sheeted dikes and the pillow lavas (Table 11).

The Ibra, Hilti, and Shafan-Kanut profiles are compared in Figure 14. The gabbro sections at both Hilti and Shafan are distinctly higher in ${ }^{18} \mathrm{O}$ than at Ibra, although all three profiles more or less coincide near the Moho. The slight ${ }^{18} \mathrm{O}$ enrichment of the gabbros in these two nortbern transects is attributed to superposition of low-temperature (prehnite) alteration, as discussed above. However, the Shafan-Kanut transect is overall lower in ${ }^{18} \mathrm{O}$ than the Ibra transect, as a result of the much lower ${ }^{18} \mathrm{O}$ values of the sheeted dikes at Shafan-Kanut. Relative to Ibra and Rajmi, the zone of ${ }^{18} \mathrm{Odepletion}$ at Shafan-Kanut is displaced to much higher levels in the oceanic crustal section, clearly a result of the hydrothermal activity associated with the late, high-level intrusions at Shafan-Kanut. The Hilti and Ibra ${ }^{18} \mathrm{O}$ profiles virtually coincide above the base of the SDC, but both are very distinct from Shafan-Kanut.

\section{${ }^{18} \mathrm{O}{ }^{16} \mathrm{O}$ in Other Areas}

Several samples from other areas in the northern Samail ophiolite were studied in this work (Table 4), to provide a more extensive database for the mass balance calculation below. It was especially important to have a representative number of all generations of dikes and extrusives, because their isotopic differences are not indicated in previous studies. These regional samples include (1) a set of samples from the pillow lavas and sheeted dikes in the Wadi Jizi area (Figure 2), including a couple of very high-level plagiogranite bodies that cut the pillow lavas in the Alley. (2) A set of samples from the Wadi Ahin sheeted dike complex (Figure 2), located just southeast of the Hilti area, and (3) the highly altered pillow lavas from the mineralized zone beneath the Lasail ore deposit.

The Wadi Jizi samples are interesting mainly from the point of view of the material-balance discussion outlined below. Here, we note simply that the sheeted dikes have $\delta^{18} \mathrm{O}=+5.5$ to +9.7 , distinctly lower than the pillow lavas which have $\delta^{18} \mathrm{O}=+10.3$ to 13.8. None of these lava samples are from the lowermost extrusive unit (Geotimes), which was metamorphosed in the greenschist facies. The lower- ${ }^{18} \mathrm{O}$ samples are from the middle or Lasail unit $(+10.3$ to +12.1$)$ and the higher $-{ }^{18} \mathrm{O}$ samples are from the upper, or Alley, unit $(+12.7$ to +13.8$)$, metamorphosed in the zeolite facies. Similarly high $\delta^{18} \mathrm{O}$ values are also observed in several very high-level plagiogranites that cut these high- ${ }^{18} \mathrm{O}$ pillows in the Alley $(+12.7$ to +13.5 , Table 4$)$. Thus, there appears to be a good correlation among the three parameters of metamorphic grade, structural height in the ophiolite complex, and whole rock $\delta^{18} \mathrm{O}$.

The main reason for going to the Wadi Ahin locality was to sample the truly impressive array of N-S trending, parallel dikes 


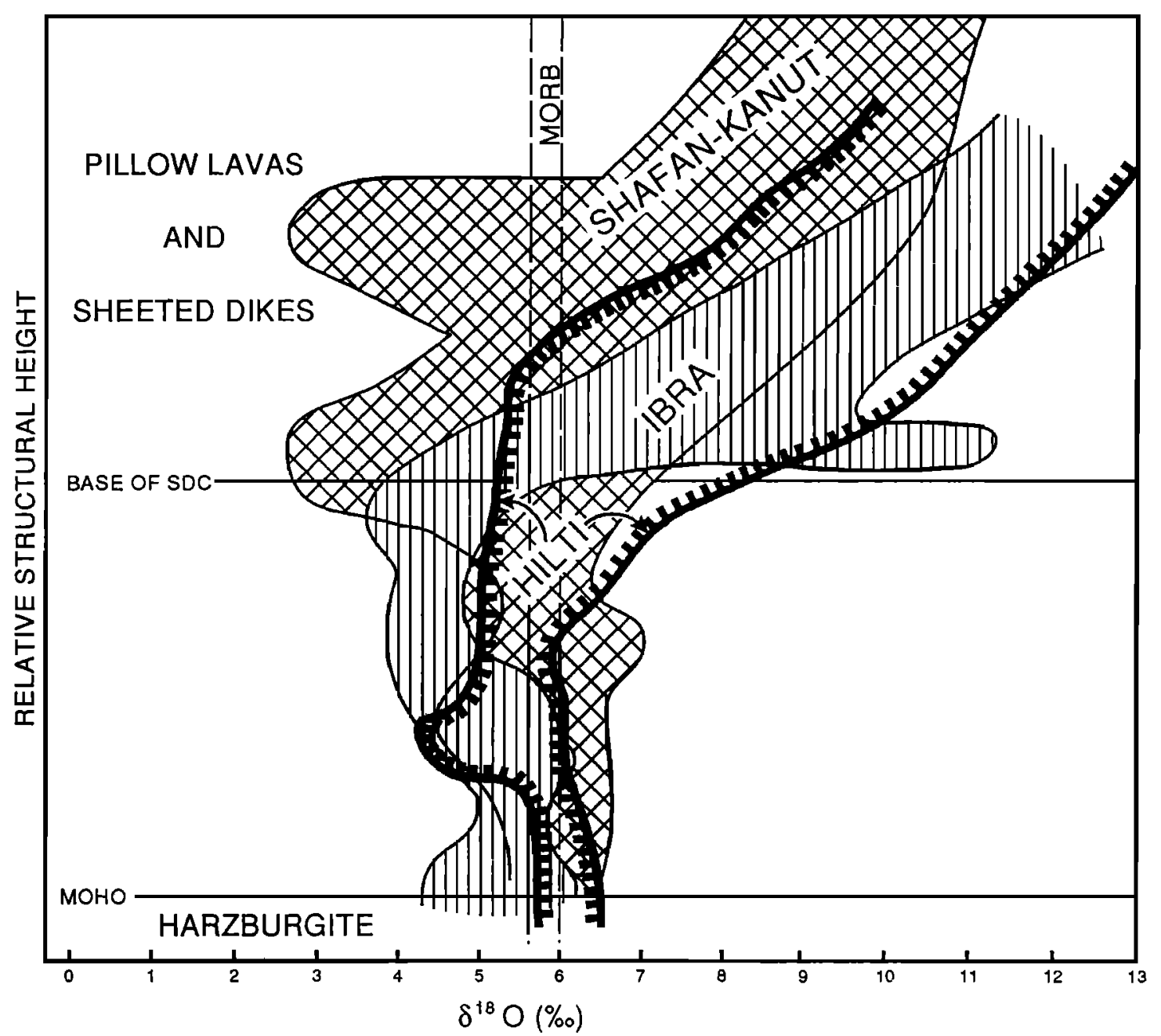

Fig. 14. Comparison of the $\delta^{18} O$ versus depth profile from Figures 9 and 10 for Wadi Hilti and Wadi Shafan-Wadi Kanut with the analogous profile of the composite Wadi Saq-Wadi Kadir section from the Ibra area [Gregory and Taylor, 1981]. These are all normalized to the same scale of distance between the Moho and the base of the SDC.

that stretch for tens of kilometers along strike. There is also a minor set of conspicuous sheets/sills that cross these axis dikes at an oblique angle. The Wadi Ahin SDC is overall extremely low in $\delta^{18} \mathrm{O},+3.2$ to +7.8 . The high-level gabbro collected just beneath the SDC at this locality is also low in $\delta^{18} \mathrm{O},+5.2$. These relatively low values indicate either that (1) these are values imprinted at the spreading center by the high-temperature hydrothermal activity that we expect there, and then (perhaps because of the vagaries of the hydrothermal "plumbing" system) these samples were subsequently "protected" from the high- ${ }^{18} \mathrm{O}$, lowertemperature overprint that we see elsewhere in the ophiolite; or (2) there is a hidden, higher-level, off-axis intrusion like that in the Wadi Kanut area, and this has caused a late stage, high-temperature overprint. To the south, a late gabbro and a late peridotite are in fact mapped as truncated (or intruded along?) a fault. Also, a nearby section contains a very thick isotropic gabbro body that extends deep into the layered gabbro.

\section{Lasail Mine Samples}

Ten samples from the Lasail mine stockworks were analyzed, including subsamples from a diamond drill core (DH2-samples) and hand-samples collected underground from the 70-m level (OMLC series) and the 100-m level (85 series). Petrographic description of these samples, their field relationships and the relationship to copper-sulfide ore distribution is discussed by $D$. S. Stakes and H. P. Taylor, Jr. (manuscript in preparation, 1992). The isotopic data are pertinent to the present discussion, and are included in the mass balance calculation given below.

Geotimes lavas form the footwall of the ore deposit and presumably are the host for the stockwork breccia. The overlying greenish lavas have been interpreted as part of the Lasail series [Alabaster and Pearce, 1985]. The stockwork is composed of chloritized basalt talus crosscut by a complex series of (mostly quartz) veins. Most samples of chlorite-rich breccia (e.g., DH2950 and OMLC-45) are strongly depleted in ${ }^{18} \mathrm{O}$ compared to MORB, but the average $\delta^{18} \mathrm{O}$ for the 10 samples, which includes some quartz veining, is +5.6 .

\section{Material.Balance ${ }^{18} \mathrm{O} /{ }^{16} \mathrm{O}$ Calculation}

The only way to make a true material balance ${ }^{18} \mathrm{O} /{ }^{16} \mathrm{O}$ calculation for the entire Samail ophiolite would be to systematically sample it on a random grid. Even then, problems would arise because of the vagaries of erosion and the nature of the outcrops (e.g., the pillow lavas and sheeted dikes do not, in general, crop out as nicely as the gabbros). Thus, one must in any case subdivide the ophiolite into separate units, systematically sample each unit, and then accurately estimate the proportions of each unit. This is not easy to do, even in an area like Oman where the 
TABLE 11. Average Whole-Rock $\delta^{18}$ O Values of Selected Portions of Various Transects Across the Samail Ophiolite ${ }^{a}$ Bulk Average

\begin{tabular}{|c|c|c|c|c|c|}
\hline \multirow[b]{2}{*}{ Transect } & \multirow[b]{2}{*}{ Gabbro } & \multirow[b]{2}{*}{ SDC } & \multirow[b]{2}{*}{ Pillow Lavas } & \multicolumn{2}{|c|}{ Bulk Average } \\
\hline & & & & Unweighted & Weighted ${ }^{b}$ \\
\hline Wadi Hilti & $+5.57(7)$ & $+7.88(5)$ & $+10.20(3)$ & $+7.27(15)$ & +6.61 \\
\hline Wadi Shafan-Kanut & $+5.43(16)$ & $+6.61(17)$ & -- & $+6.04(33)$ & +6.09 \\
\hline Wadi Rajmi & $+4.86(42)$ & $+6.65(4)$ & $+7.80(1)$ & $+5.07(47)$ & +559 \\
\hline Ibra Area ${ }^{c}$ & $+5.34(18)$ & $+8.15(8)$ & $+12.70(1)$ & $+6.44(27)$ & +6.81 \\
\hline$\left\{\begin{array}{l}\text { Wadi Jizi } \\
\text { Wadi Ahin } \\
\text { Lasail Stockwork }\end{array}\right.$ & -- & $+5.43(6)$ & $\begin{array}{r}+11.85(11) \\
+5.64(10)\end{array}$ & $+8.13(27)$ & +5.74 \\
\hline
\end{tabular}

Overall Bulk Average for the Entire Ophiolite

$\begin{array}{llllll}\text { Unweighted } & +5.13(83) & +6.90(40) & +9.15(26) & +6.31(149)^{d} \\ \text { Weighted }^{e} & +5.30(4) & +7.05(5) & +9.64(5) & +6.19(3)^{f} & +6.17(5)^{g}\end{array}$

\footnotetext{
${ }^{a}$ Wumbers of samples analyzed are given in parentheses. two entries for which no data are given, we use the average $\delta^{18} O$ value for that unit listed below for the entire ophiolite (weighted value).

'Data from Gregory and Taylor [1981].

${ }^{d}$ Simple unweighted average of all 149 whole-rock samples analyzed to date by us and by Gregony and Taylor [1981] from the Samail ophiolite (this value is, of course, also identical to the weighted average of the three entries to the left in this same row, as well as the weighted average of the five entries above in this same column).

eSimple averages of the average whole rock $\delta^{18} \mathrm{O}$ values at the four or five localities listed above, with each locality weighted equally.

Weighted average of the weighted values to the left in this row, assuming the same proportions listed above for the three major stratigraphic units.

This is the average $\delta^{18} \mathrm{O}$ value of the five weighted values for each transect listed above in this same column.

${ }^{k}$ Average for the four pillow lava localities (each weighted equally) but excluding the Lasail Stockwork samples.
}

outcrops are superb, because of the heterogeneity in stratigraphic thickness, lithology, magmatic history, and intensity of hydrothermal metamorphism along the strike length of the ophiolite.

Although there was certainly an element of randomness in our sampling procedures, many of the samples listed in Tables 1-4 were collected specifically because of some unique attribute. Also, we largely ignored the ultramafic cumulates and the wehrlite portions of the late-stage intrusions, and we focused on the gabbros from Rajmi and the sheeted dike section at ShafanKanut far our of proportion to the other portions of these transects. In spite of the above complications, we believe it is important to use these data to make some crude material balance calculations.

Table 11 presents various kinds of whole rock $\delta^{18} \mathrm{O}$ averages for the Samail ophiolite. Table 11 includes all of the 149 whole rock analyses available from Tables 14 and from Gregory and Taylor [1981]. The simple, unweighted (mindless!) average of all of these data is +6.31 , which is just slightly higher in ${ }^{18} \mathrm{O}$ than the characteristic MORB $\delta^{18} \mathrm{O}$ value of +5.8 . More meaningful values are listed in the weighted bulk average column, where for simplicity we assumed a constant proportionality among the sizes of the three major stratigraphic units of the ophiolite, basing these on a "normal" oceanic crustal thickness of $6.0 \mathrm{~km}$ : (1) $4.0 \mathrm{~km}$ of layered gabbro and isotropic gabbro, including the associated later-stage wehrlite, gabbro, and plagiogranite intrusions (see Figure 11); (2) $1.3 \mathrm{~km}$ of sheeted dikes; and (3) $0.7 \mathrm{~km}$ of pillow lavas; (4)also, for simplicity we lumped the data from three widely separated localities from Table 4 all together to provide a fifth ("composite") transect (Ahin, Jizi, Lasail). The proportions of the three major units of oceanic crust given above (4.0: 1.3: 0.7) represent our best estimates for the entire Samail ophiolite. Ob- viously these proportions do not accurately reflect each individual transect, as Shafan for example contains relatively less gabbro and Ibra and Hilti contain more.

For the four transects in our own data set, the weighted bulk averages range from a low of $\mathbf{+ 5 . 5 9}$ at Wadi Rajmi to a high of +6.61 at Wadi Hilti. It thus seems clear that it is not just the gabbros, but the entire Wadi Rajmi section that has overall become slightly depleted in ${ }^{18} \mathrm{O}$. In contrast, at Wadi Hilti, the entire section has become slightly enriched in ${ }^{18} \mathrm{O}$. The integrated values of the Shafan-Kanut and the "composite" Jizi-Ahin-Lasail transects are virtually unchanged from the typical MORB values. Somewhat of a surprise in this method of calculation is the very high $\delta^{18} \mathrm{O}$ of +6.81 obtained for the Ibra transect in Table 11 . However, this is clearly attributable to the high $\delta^{18} \mathrm{O}$ of the SDC at Ibra $(+8.15)$ and to the very high $\delta^{18} \mathrm{O}$ of the single pillow lava analyzed (+12.7). This average for Ibra would be brought down by $0.36 \%$ to +6.45 , if the weighted average $\delta^{18} \mathrm{O}$ for all the pillow lava localities $(+9.64)$ were used instead of the +12.7 value. Gregory and Taylor [1981] reported an average $\delta^{18} \mathrm{O}$ of about $+5.8 \pm 0.3$ for the Ibra transect, not $\mathbf{+ 6 . 4 5}$ or +6.81 as in Table 11. This discrepancy is a result of the crudity of our materialbalance calculations, because the actual proportion of gabbro relative to pillow lavas in the stratigraphic section at Ibra is larger than that assumed above [Gregory and Taylor, 1981].

In spite of all the difficulties and qualifications attached to the averages listed in Table 11, some clear-cut conclusions arise: (1) The plutonic portions of most transects through the oceanic crust are overall distinctly depleted in ${ }^{18} \mathrm{O}$ relative to $\mathrm{MORB}$, and both the weighted and unweighted bulk averages of all of the gabbros so far analyzed are similar at $\delta^{18} \mathrm{O}=+5.1$ to +5.3 . (2) In contrast, except for the sheeted dikes at Wadi Ahin and the stockwork vein 
system of the Lasail ore deposit, the SDC and particularly the pillow lavas are everywhere distinctly enriched in ${ }^{18} \mathrm{O}$ relative to MORB. (3) The crude weighted bulk averages for each transect range only from +5.6 to +6.6 (if for Ibra, we use the better constrained value of $+5.8 \pm 0.3$ from Gregory and Taylor [1981]). (4) Three different ways of averaging all of the available ${ }^{18} \mathrm{O} /{ }^{16} \mathrm{O}$ data from the various transects give very similar results $(+6.17$ to +6.31 ); note also that the +6.17 value, obtained by averaging the bulk averages for all of the five transects, would be reduced to +5.97 if we replace the clearly incorrect +6.81 value for Ibra with the more accurate estimate of +5.8 from Gregory and Taylor [1981].

What then are we to make of the three different kinds of bulk average that range from +5.97 to +6.31 ? Within our sampling error and experimental error, these values are essentially identical to the average MORB basalt value of about +5.8 . Thus one plausible conclusion is that in spite of all of the complex lateral and vertical ${ }^{18} \mathrm{O} /{ }^{16} \mathrm{O}$ heterogeneities in the Samail oceanic crust, there has been virtually no change in the bulk $\delta^{18} \mathrm{O}$ of this package of rocks, because: (1) the upper level ${ }^{18} \mathrm{O}$ enrichments are essentially canceled out by the lower-level ${ }^{18} \mathrm{O}$ depletions; and (2) the slight ${ }^{18} \mathrm{O}$ enrichments of structurally simple, intact oceanic crust are balanced by the ${ }^{18} \mathrm{O}$ depletions in the highly deformed crust penetrated by abundant late stage intrusions. This strongly supports, validates, and amplifies the fundamental conclusion of Gregory and Taylor [1981], that the $\delta^{18} \mathrm{O}$ of ocean water is closely buffered and controlled by the integrated series of overlapping mid-ocean ridge and subsequent off-axis hydrothermal processes. This conclusion can now be basically applied to the entire 500,000 $\mathrm{km}^{3}$ volume of oceanic crust in the Samail ophiolite, not just to the small area around Ibra in the southern part of this body. However, is the 0.2-0.5\%o $\delta^{18} \mathrm{O}$ difference between MORB and the averages in Table 11 real, or simply a result of the crude sampling procedures? There are a number of ways of looking at this question.

One obvious possibility is that the original magmas that formed the bulk of the Samail ophiolite did not have a MORB-type $\delta^{18} \mathrm{O}$ $=+5.8$ but were higher by about $0.2-0.5 \%$, particularly given the fact that other workers have suggested a non-MORB origin for parts of the ophiolite (e.g., the wehrlite suite of magmas in the northern part). Several workers have suggested that the northern Samail magmas have island arc affinities or that they are formed by melting of hydrous mantle. Such materials could have started out with $\delta^{18} \mathrm{O}$ values as high as +6.5 or even higher, because oceanic magmatism is known to have produced such values in certain environments (see reviews by Kyser [1986], Taylor [1986], and Taylor and Sheppard [1986]).

Another reason why the material balance $\delta^{18} \mathrm{O}$ values might be too high is that our sampling has focused almost totally on the plagioclase-bearing rocks; the ultramafic units in the oceanic crustal section have been avoided and essentially ignored, for three main reasons: (1) we concentrated on plagioclase because it is by far the best mineral to analyze in order to monitor hydrothermal alteration effects in these kinds of rocks [e.g., Taylor, 1974; Taylor and Forester, 1979]; (2) the olivine-rich rocks are heavily serpentinized, and because we know that much of this serpentinization is subaerial in origin, it is clear that the original sea-floor ${ }^{18} \mathrm{O}$ signature of those rocks has been disturbed (see below and Barnes et al. [1978]); (3) the ultramafic units are not very abundant, so their exclusion will not be all that important to the overall material balance. The ultramafic rocks probably all started out with primary $\delta^{18} \mathrm{O}$ values about $1 \%$ lower in ${ }^{18} \mathrm{O}$ than MORB (i.e., with the typical $\delta^{18} \mathrm{O}$ values of pyroxene and olivine in basaltic magmas), and those that were altered to chlorite and amphibole at moderate to high temperatures and moderate to high water/rock ratios would all be lowered in ${ }^{18} \mathrm{O}$ even further (down to values of +2 to +4 , see the amphibole $\delta^{18} \mathrm{O}$ values in Figure 15 and Tables 1-4). Another factor is that the cumulate ultramafics are not the only rocks of this type that have been excluded. Particularly in the northern Samail ophiolite there are numerous later-stage wehrlite sills, pods, and dikes (e.g. see Figure 11). If we were to add about $5 \%$ of ultramafic material with $\delta^{18} \mathrm{O}=+3.5$ to +4.0 to the sections listed in Table 11 , the bulk values would be lowered by about $0.15 \%$, thereby making them much closer to MORB.

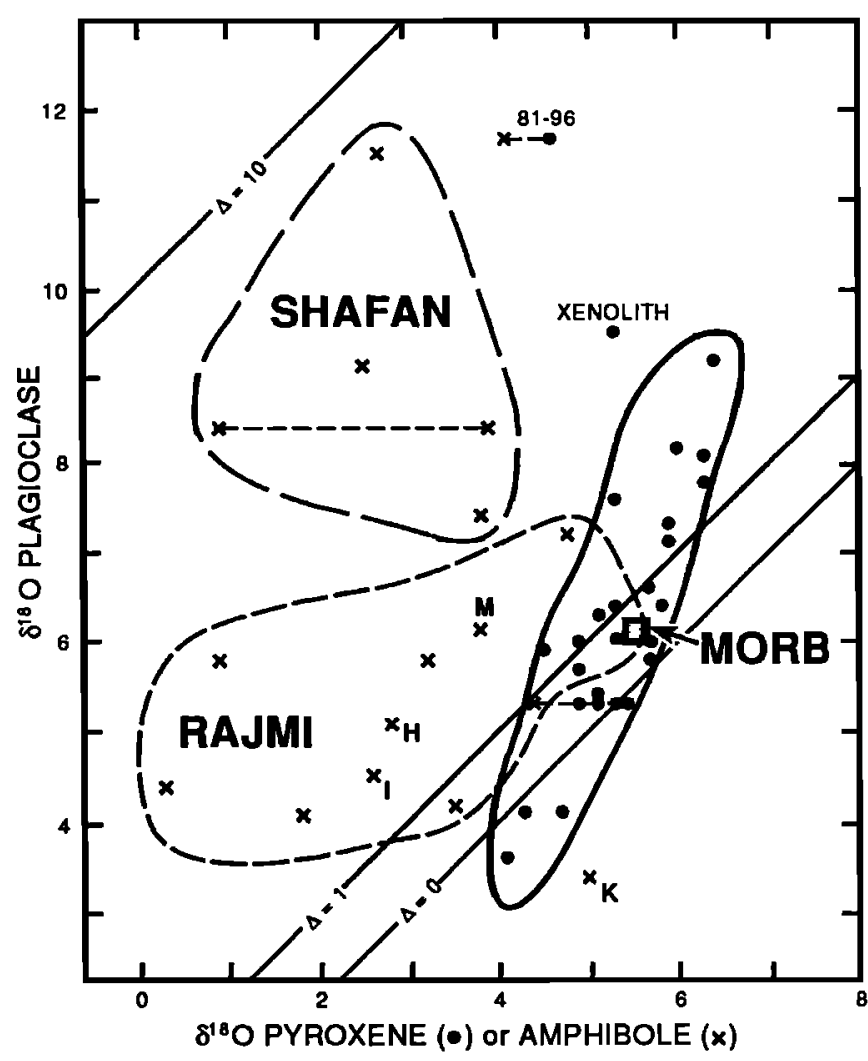

Fig. 15. Plot of $\delta^{18} \mathrm{O}$ plagioclase versus $\delta^{18} \mathrm{O}$ clinopyroxene or $\delta^{18} \mathrm{O}$ amphibole for samples from the Samail Ophiolite, including data from the present work and from Gregory and Tayior [1981]. The diagonal lines at $\Delta=0$ and $\Delta=1$ encompass the normal, high-temperature equilibrium fractionation between plagioclase and pyroxene in basalts and layered gabbros, and the stippled square is the characteristic range of $\delta^{80} \mathrm{O}$ in coexisting plagioclase and clinopyroxene in fresh, unaltered MORB. The field with a steep positive slope that is enclosed by a solid curve is the pyroxene-plagioctase ${ }^{18} \mathrm{O} /{ }^{16} \mathrm{O}$ envelope for the Ibra area in the southern Samail Ophiolite, originally defined by Gregory and Taylor [1981]. This envelope also encompasses all such mineral pairs analyzed in the present study except for the 81-96 Moho sample from Wadi Rajmi and a prehnitized xenolith from Wadi Hilti (see text). The low- ${ }^{18} \mathrm{O}$ amphiboles enclosed by the two dashed envelopes illustrate the striking differences between the Wadi Rajmi and Wadi Shafan profiles. Both sets of data indicate amphibole formation during a high-temperature, $10 \mathrm{w}-{ }^{18} \mathrm{O}$ stage of hydrothermal alteration, followed by a much lower temperature event that preferentially raised the $\delta^{18} \mathrm{O}$ values of plagioclase; this high- ${ }^{18} \mathrm{O}$ event is particularly noticeable in the Shafan samples. Note that the diagonal line at $\Delta=10$ represents an absurdly large equilibrium ${ }^{18} \mathrm{O} /{ }^{16} \mathrm{O}$ fractionation between either plagioclase and amphibole or between plagioclase and pyroxene, even if the temperature of exchange is extremelow, Clearty, the Shafan plagioclase-amphibole pairs do not represent ${ }^{18} \mathrm{O} /{ }^{16} \mathrm{O}$ equilibrium. The horizontal dashed lines connect analyses of coexisting mineral pairs. Single plagioclase-amphibole pairs are plotted for the following localities: M, Musafiyah; K, Kanut; I, Ibra; H, Hilti 
On the other hand, if instead of trying to explain away the half per mil discrepancy, we conclude that both this effect and the ${ }^{18} \mathrm{O} /{ }^{16} \mathrm{O}$ buffering of the hydrosphere are valid, they together would demand that the hydrosphere-crust interactions on Earth must be somewhat out of balance in the opposite direction. Stated another way, because of the constraints of material balance, we cannot over the course of billions of years of geologic time continue to subduct such ${ }^{18} \mathrm{O}$-rich oceanic lithosphere and permanently emplace it into the mantle without progressively and continuously depleting ${ }^{18} \mathrm{O}$ in some other reservoir (e.g., the hydrosphere or some other part of the Earth's crust). If we keep the hydrosphere isotopically uniform, then somewhere else on Earth the lithosphere must be sufficiently depleted in ${ }^{18} \mathrm{O}$ (and the hydrosphere thereby sufficiently enriched in ${ }^{18} \mathrm{O}$ ) to remove the discrepancy. This would have to be a much larger overall shift than 0.2-0.5\%o because the submarine hydrothermal activity and weathering certainly dominates the overall material balance [Muehlenbachs and Clayton, 1976; Gregory and Taylor, 1981; Gregory, 1991]. Low-temperature continental weathering is in the wrong direction to balance the discrepancy, so we are left with either (1) regional and contact metamorphism (and perhaps diagenesis) which are known to lower the $\delta^{18} \mathrm{O}$ of sedimentary rocks through water/rock interactions [e.g., Wickham and Taylor, 1985, 1987]; or (2) continental meteoric-hydrothermal effects, which have been shown in the past two decades to be much more extensive than was heretofore thought [e.g., Criss and Taylor, 1986]. It is important to continue gathering data on the overall importance of these two reservoirs of ${ }^{18} \mathrm{O}$-depleted rocks to see just how effective they might be in accounting for the ${ }^{18} \mathrm{O} /{ }^{16} \mathrm{O}$ discrepancies.

Another speculative way out of this dilemma might be as follows: We know that the upper part of the oceanic lithosphere that is being subducted on a global scale is very heterogeneous in $\delta^{18} \mathrm{O}$ and in the abundances of hydrothermal minerals (e.g., see Figures 9,10 , and 12). If the uppermost ${ }^{18} \mathrm{O}$-rich and $\mathrm{H}_{2} \mathrm{O}$-rich parts of this lithosphere are returned to the crust by processes of melting in and above subduction zones, followed by upward migration of these higher ${ }^{18} \mathrm{O}$ magma bodies into the crust, while the lower, more anhydrous, ${ }^{18} \mathrm{O}$-depleted parts of the subducted lithosphere are left behind in the upper mantle, this could be sufficient to account for the discrepancy. In fact, island arc magmas do tend to be slightly richer in ${ }^{18} \mathrm{O}$ than MORB, and some plutonic complexes formed in subduction zone environments are extremely ${ }^{18} \mathrm{O}$ rich (e.g., Peninsular Ranges Batholith, +9 to +12 [see Taylor, 1986]). Also, there is plenty of evidence that some ${ }^{18} \mathrm{O}$ depleted material has indeed been left behind in the upper mantle in the form of eclogites [Vogel and Garlick, 1970; Garlick et al, 1971].

We also must consider one other possible explanation of the slight ${ }^{18} \mathrm{O}$ enrichment of the integrated oceanic crustal section exhibited by the Samail ophiolite. In applying mass balance calculations to the Samail ophiolite, and extrapolating these as representing the average properties of all oceanic crust on Earth, we and Gregory and Taylor [1981] are both implicitly assuming that all of the submarine ${ }^{18} \mathrm{O} /{ }^{16} \mathrm{O}$ effects that we observe in the ophiolite will also be found in normal oceanic crust. However, most oceanic crust does not undergo detachment and subsequent obduction; therefore, if a significant ${ }^{18} \mathrm{O}$ enrichment event can be demonstrated to have occurred in the ophiolite solely as a result of the obduction process itself, then these ${ }^{18} \mathrm{O}$ effects obviously should be subtracted from the overall mass balance estimate (even if the process was entirely a submarine phenomenon).

We know that the Samail ophiolite has been subjected to a late stage, very low-temperature alteration that has enriched the rocks in ${ }^{18} \mathrm{O}$ ( by an unknown amount). If this alteration was entirely a submarine phenomenon, associated with the obduction process and not with the subduction process, or if this low-temperature ${ }^{18} \mathrm{O}$ enrichment occurred at a later stage during alteration by fresh, meteoric waters, then this might account for the slight ${ }^{18} \mathrm{O} /{ }^{16} \mathrm{O}$ discrepancy, because such isotopic effects would then not be part of the "normal" basaltic crust-ocean interaction. In fact, much (perhaps all) of the serpentinization of the mantle section of the Samail ophiolite has been shown to be a subaerial phenomenon [Coleman, 1981; Barnes et al., 1978]. Zeolites and other minerals in the pillow lavas (e.g., the fine-grained calcite from Shafan sample 81-140) are known to exchange with aqueous fluids with notorious ease, even at very low temperatures [Feng and Savin, 1991], and it is plausible that there has indeed been a slight overall ${ }^{18} \mathrm{O}$ enrichment of the ophiolite subsequent to its obduction. It is certain that if this process occurred, it would be unidirectional, producing an ${ }^{18} \mathrm{O}$ enrichment, because it would be such a low-temperature process. Other evidence for such a phenomenon is presented below.

\section{EXTREME ${ }^{18}$ O ENRICHMENT IN THE VICINITY OF THE МOHO}

Gregory and Taylor [1981] noted in the Ibra section that: (1) all six samples of gabbro dikes cutting the mantle peridotites exhibit very high $\delta^{18} \mathrm{O}$ plagioclase values of +7.1 to +9.2 , and the primary minerals in all these samples are variably replaced and veined by hydrogarnet and prehnite; and (2) within the lower cumulate gabbros, the only two samples with $\delta^{18} \mathrm{O}$ plagioclase $>+6.0(+6.4$ and +6.6 ) are also the only analyzed gabbros at Ibra that are cut by veins containing hydrogarnet and/or prehnite. These lowtemperature minerals are rare in the Ibra area, so the correlation between high $\delta^{18} \mathrm{O}$ and this type of mineralogical alteration implies a common origin.

In our own work discussed above, we have pointed out the much greater abundance of prehnite and other low-temperature hydrous minerals in the northern part of the ophiolite as compared to the Ibra section, as well as the association of these minerals with relatively high $-{ }^{18} \mathrm{O}$ plagioclase. In addition, the data in Tables 1,2, and 3 indicate the following: (1) the deepest gabbro sample (81-96) at Wadi Rajmi also contains by far the highest- ${ }^{18} \mathrm{O}$ plagioclase in that entire section of gabbros $\left(\delta^{18} \mathrm{O}=+11.7\right)$, even though this plagioclase coexists with low- ${ }^{18} \mathrm{O}$ pyroxene and amphibole; (2) by far the highest- ${ }^{18} \mathrm{O}$ plagioclase in the entire Wadi Hilti layered gabbro also occurs in the deepest sample (81-201, $\delta^{18} \mathrm{O}=+7.6$; and $(3)$ the deepest gabbro from Wadi-Shafan (81-122) also has an extremely high $\delta^{18} \mathrm{O}$ plagioclase value, +8.4 , although even higher $\delta^{18} \mathrm{O}$ values $(+9.1$ and +11.5$)$ occur locally higher in the section.

The features listed above indicate that in the vicinity of the layered gabbro-harzburgite contact, there is evidence for some kind of preferential late-stage penetration by high- ${ }^{18} \mathrm{O}$ aqueous fluids all along the strike of the Samail ophiolite. This influx may have begun at high temperatures soon after the gabbros were able to sustain open fractures, but it must have continued to occur well away from the spreading axis, even after the temperatures had dropped to $400^{\circ} \mathrm{C}$, because of the relationship between the high $\delta^{18} \mathrm{O}$ values and the alteration mineralogy. It is tempting to speculate that some type of structural dislocation at or near the oceanic Moho has provided the access for these aqueous fluids. In this connection, Boudier et al. [1985] have presented evidence for appropriate types of fracture conduits, in their description of region-wide shear zones in the peridotites just below the Moho. 
These shear zones are continuous with the basal thrusts in the ophiolite, and Boudier et al. [1985] argue that detachment initially occurred at an early stage near the ridge, where it was very likely associated with off-axis magmatism, and that thrusting at this structural level continued well away from the spreading axis. The continued episodes of fracturing that would be focused along these shear zones, together with the great lateral continuity suggested for these zones by Boudier et al. [1985], are a plausible explanation of the anomalously high fluid-rock ratios that are required at this horizon throughout the ophiolite. The long circulation path required for these fluids to penetrate both downward through the crust and laterally for quite a distance would enable the fluids to exchange with sufficient rock to attain the required high $\delta^{18} \mathrm{O}$ values.

\section{${ }^{18} \mathrm{O} /{ }^{16} \mathrm{O}$ Ratios of COEXISTing Minerals}

The $\delta^{18} \mathrm{O}$ analyses of coexisting plagioclase, clinopyroxene, and amphibole from this study are plotted on Figure 15, where they are compared with analogous data obtained by Gregory and Taylor [1981]. In contrast to their study, our new data emphasize amphibole-feldspar pairs, rather than pyroxene-feldspar pairs, particularly for the low- ${ }^{18} \mathrm{O}$ samples. This is because amphibole alteration of pyroxene is much more pervasive in our samples, and it was therefore correspondingly much more difficult to obtain pure clinopyroxene separates. This is particularly true of the samples that have undergone intensive ${ }^{18} \mathrm{O}$-depletion, as already indicated. Virtually every such pyroxene is partly to completely altered to amphibole (commonly more than one compositional type).

For the above reasons, and also because we did not sample any of the high $-{ }^{18} \mathrm{O}$ gabbro dikes that cut the mantle harzburgite well beneath the Moho, the bulk of our plagioclase-pyroxene pairs show a much more restricted range of ${ }^{18} \mathrm{O}$ than those studied by Gregory and Taylor [1981]. As shown in Figure 15, most of our pairs plot in the same general field outlined by Gregory and Taylor [1981], but they do not extend to the extremities of this data point envelope. These kinds of plagoclase-pyroxene systematics (with a quasi-linear pattern that exhibits a steep slope) are a general characteristic of hydrothermally altered gabbros, and this phenomenon has been thoroughly discussed in several recent papers [e.g., Gregory and Taylor, 1981; Gregory et al., 1989]. These published discussions clearly apply to the gabbros from the northern Samail ophiolite as well, and they will not be repeated here.

Note the broad field of $\delta^{18} \mathrm{O}$ values displayed by the plagioclaseamphibole pairs (Figure 15). Many samples (particularly some deep-level samples from Wadi Rajmi) exhibit extreme ${ }^{18} \mathrm{O}$ depletion in both plagioclase and amphibole. The hydrothermal exchange kinetics of amphibole are somewhat similar to those of pyroxene; both minerals are much more resistant to ${ }^{18} \mathrm{O} /{ }^{16} \mathrm{O}$ exchange during water-rock exchange than is coexisting plagioclase [Gregory et al., 1989]. Thus, the most plausible interpretation of the low- ${ }^{18} \mathrm{O}$ amphiboles given in Figure 15 and Tables $1-4\left(\delta^{18} \mathrm{O}=+0.3\right.$ to 3.9$)$ is that they were either deposited or recrystallized in the presence of a high-temperature, relatively low- ${ }^{18} \mathrm{O}$ marine-hydrothermal fluid.

Some of the plagioclase-amphibole ${ }^{18} \mathrm{O} /{ }^{16} \mathrm{O}$ fractionations ( $\Delta$ values) represent plausible equilibrium fractionations at hydrothermal temperatures (i.e., $\Delta$ plagioclase-amphibole $=3 \%$ ). However, many of the others, particularly those from Wadi Shafan, exhibit $\Delta$ values as high as 6 to $9 \%$ ! These cannot possibly represent ${ }^{18} \mathrm{O} /{ }^{16} \mathrm{O}$ equilibrium at any plausible temperature, and thus they constitute our best available evidence that parts of the northern Samail ophiolite (particularly in Wadi Shafan) underwent a high-temperature hydrothermal event prior to the later stage episode that produced the strong ${ }^{18} \mathrm{O}$ enrichments in the coexisting plagioclase. The deep sample 81-122 from Wadi Shafan just above the Moho (discussed above) is particularly compelling in this regard, with an amphibole $\delta^{18} \mathrm{O}$ of +0.9 coexisting with another amphibole with $\delta^{18} \mathrm{O}=+3.9$, and both coexisting with a strongly ${ }^{18} \mathrm{O}$-enriched plagioclase $\left(\delta^{18} \mathrm{O}=+8.4\right.$, giving $\Delta$-values of 7.5 and 4.5). Analogous effects are also observed in the Rajmi sample 81-96 collected just above the Moho, which exhibits a $\Delta$ value of 7.6 (as well as a plagioclase-pyroxene fractionation of 7.1 !). Such ${ }^{18} \mathrm{O} /{ }^{16} \mathrm{O}$ systematics require that a high-temperature, ${ }^{18} \mathrm{O}$ depletion event had to occur before the late stage, low-temperature hydrothermal event that produced ${ }^{18}$ Oenrichment of the feldspar; the latter was probably associated with the prehnitization event, as already discussed.

\section{SUMMARY AND CONCLUSIONS}

We may summarize one of the major conclusions of this work in a single paragraph: Our new data require that we modify and amplify the important conclusion of Gregory and Taylor [1981] that "in spite of great heterogeneity in ${ }^{18} \mathrm{O} /{ }^{16} \mathrm{O}$, a vertical section through hydrothermally altered oceanic crust has an integrated $\delta^{18} \mathrm{O}$ essentially identical to that of the original basaltic magmas from which it was formed". Within experimental and sampling error, this general conclusion is still valid, but only if we extend the vertical ${ }^{18} \mathrm{O} /{ }^{16} \mathrm{O}$ heterogeneity to include considerable lateral ${ }^{18} \mathrm{O} /{ }^{16} \mathrm{O}$ heterogeneity in the oceanic crust, and only if we integrate the subsolidus hydrothermal effects across the entire three-dimensional volume of the ophiolite, not just through a vertical section; we must also include all submarine intrusive and hydrothermal events that occurred both off-axis and at the spreading ridge to create the composite crust.

It is clear that Gregory and Taylor [1981] made all of their original traverses in a relatively average part of the Samail ophiolite, because our extension of their work shows that there is considerable along-strike ${ }^{18} \mathrm{O} /{ }^{16} \mathrm{O}$ variation in this body, in addition to the kind of vertical ${ }^{18} \mathrm{O} /{ }^{16} \mathrm{O}$ variation described by them in the Ibra area. Some sections are overall depleted in ${ }^{18} \mathrm{O}$ relative to MORB (e.g., Wadi Rajmi) and some are enriched in ${ }^{18} \mathrm{O}$ (e.g., Wadi Hilti); thus, based on the bulk averages listed above in Table 11, it is clear that there is an overall lateral "canceling" of ${ }^{18} \mathrm{O} /{ }^{16} \mathrm{O}$ effects as well as a vertical "canceling". There, are however, also a lot of temporal complexities and heterogeneities in ${ }^{18} \mathrm{O} /{ }^{16} \mathrm{O}$ distribution, because as the crust moves away from the spreading axis, convective hydrothermal circulation persists around the younger intrusions that are very common in our transects, superimposing a secondary isotopic overprint; these effects are much more difficult to sort out, because in general we only see the final result.

Because of limitations in our sampling procedure, together with the enormous outcrop area to be sampled, we were able to calculate only a crude material balance $\delta^{18} \mathrm{O}$ value for the entire ophiolite, about +5.9 to +6.3 . Within sampling error, this is considered to be virtually identical to the accepted MORB $\delta^{18} \mathrm{O}$ value of $+5.8 \pm 0.2$. However, we also discuss several possible reasons why our calculated mass-balance value might be real, as well as the global and/or local geological consequences of such a 0.2-0.5 \%o discrepancy. One interesting possibility that needs to be tested further is that there has been a low-temperature, high${ }^{18}$ O overprint associated with submarine and/or subaerial detachment of the ophiolite and shearing in the vicinity of the Moho. Inasmuch as such ${ }^{18} \mathrm{O} /{ }^{16} \mathrm{O}$ effects are likely to be present in 
obducted ophiolite fragments but not in normal oceanic crust, they should be subtracted from overall global mass balance estimates. This is in the right direction to explain the above ${ }^{18} \mathrm{O} /{ }^{16} \mathrm{O}$ discrepancy.

Some of the other major conclusions of this study of three major sampling transects across the northern Samail ophiolite are as follows:

1. The least structurally complex transect (Wadi Hilti) also shows the simplest $\delta^{18} \mathrm{O}$ systematics. This transect is similar to the Ibra profile of Gregory and Taylor [1981] except that it lacks the striking ${ }^{18} \mathrm{O}$ depletions of the middle and upper layered gabbros. The ${ }^{18} \mathrm{O}$ depletions in the Ibra area were produced by high-temperature hydrothermal activity at the spreading center during the cooling of these gabbros. Similar features were probably also present at Wadi Hilti but may have been overprinted by the deep, late stage, lower-temperature hydrothermal alteration event that characterizes all of the transects in the northern part of the ophiolite.

2. Much more complex ${ }^{18} \mathrm{O} /{ }^{16} \mathrm{O}$ effects were observed in the Shafan-Kanut transect, which was sampled specifically to examine the effects of some major high-level shear zones associated with late-stage, off-axis, gabbro-diorite-plagiogranite intrusions emplaced into the sheeted dike complex. The convective hydrothermal systems associated with these intrusions produced a proximal zone of intense ${ }^{18} \mathrm{O}$ depletion in the immediately surrounding country rocks, whereas the more distant samples in the distal part of the system were subjected to a low-temperature, high $-{ }^{18} \mathrm{O}$ overprint. The remnants of an earlier, high-temperature hydrothermal alteration of the Shafan gabbros near the spreading axis are clearly preserved in the ${ }^{18} \mathrm{O}$-depleted amphiboles, even though the coexisting plagioclases have all been strongly enriched in ${ }^{18} \mathrm{O}$ during the low-temperature overprint.

3. A third transect, in the Wadi Rajmi area, was selected for study because it was known that the lower part of this gabbro section had been subjected to a very complex episode of shearing and fracturing associated with emplacement of abundant late stage, composite, ultramafic-gabbro intrusions, gabbro pegmatites, and finer-grained off-axis dikes (this area was originally suggested to us by J. Smewing as a possible fossil transform fault, although more recent studies by Reuber [1988] are perbaps more indicative of a complex overlapping spreading center, or OSC). The $\delta^{18} \mathrm{O}$ pattern of this transect is unique in displaying a truly enormous zone of ${ }^{18} \mathrm{O}$ depletion in the lower part of the section of layered gabbros. This zone of ${ }^{18} \mathrm{O}$ depletion is much deeper and also lower in ${ }^{18} \mathrm{O}$ than the zone of ${ }^{18} \mathrm{O}$ depleted gabbros in the Ibra area to the south. The ${ }^{18} \mathrm{O} /{ }^{16} \mathrm{O}$ systematics thus make it clear that this part of the ophiolite was particularly permeable, and that very large volumes of high-temperature seawater circulated down to the Moho through the lower part of this section of oceanic crust. If this is truly a fossil OSC or transform fault zone, the ${ }^{18} \mathrm{O} /{ }^{16} \mathrm{O}$ data provide a compelling indication of the depth and intensity of seawater-rock interactions that woukd likely be associated with that kind of deformation and shearing near a spreading ridge axis. The intense hydrothermal alteration in the Rajmi area is clearly linked to the unique magmatic history of this area, e.g. the abundant orthopyroxene and the many east trending (extensional?) structures that cut obliquely across the primary ophiolite stratigraphy.

4. Our data, combined with the earlier work of Gregory and Taylor [1981], indicate that every transect through this fragment of oceanic crust probably has experienced a unique history of cooling and seawater-rock interaction. However, these processes and their effects are by no means random. Most of the ${ }^{18} \mathrm{O} /{ }^{16} \mathrm{O}$ differences among the transects can be readily related to one or the other of the following features: (1) fossil permeability, as presently evidenced in the outcrops by the size and abundance of veins and fractures; (2) superposition of a low-temperature, high${ }^{18} \mathrm{O}$ alteration associated with prehnite, chlorite, and epidote upon an earlier, higher-temperature alteration associated with ${ }^{18} \mathrm{O}$-depleted plagioclase and $10 \mathrm{w}-{ }^{18} \mathrm{O}$ amphibole; (3) presence or absence of late stage off-axis intrusions of various types, their abundance and size, and the level in the oceanic crust to which they penetrate; and (4) metamorphic grade, with the upper pillow lavas (zeolite facies) being strongly enriched in ${ }^{18} \mathrm{O}$ (to $\delta^{18} \mathrm{O}=$ +12 or higher) compared to the lower lavas (greenschist facies), and with much lower $\delta^{18} \mathrm{O}$ values of +3.3 to +7.4 where these lavas are cut by the highly chloritized stockwork vein system which provided conduits for the fluids that deposited the massive sulfide ore bodies (e.g., Lasail); these ore bodies commonly form at or near the interface between the earlier set of axis pillow lavas and a later set of off-axis extrusives.

5. Compared to the Ibra area in the southern part of the ophiolite, the geology, petrology, and mineralogy of the northern part of the Samail ophiolite are all indicative of a much more complex history of magmatism and associated hydrothermal alteration. Our ${ }^{18} \mathrm{O} /{ }^{16} \mathrm{O}$ data in general confirm these complexities, and the detailed features of the isotopic data can be readily related to specific features of the geology. Although the hydrothermal effects at the spreading axis are also clearly recognizable in the north, there has been a much heavier overprinting by later off-axis events in the north than in the south. This is evidenced by the fact that hydrous minerals are much more abundant in the lower parts of the gabbro section in the north, as a result of (1) the heterogeneous overprint of high-temperature, $10 w-{ }^{18} \mathrm{O}$ alteration associated with the much more abundant off-axis intrusions, which are intruded at a variety of levels; and (2) a high $-{ }^{18} \mathrm{O}$ overprint associated with either the overlapping distal portions of 1 , or the result of a regional low-temperature event that has penetrated much deeper in the north because of the greater fracture permeability there. This high- ${ }^{18} \mathrm{O}$ event(s) is associated with abundant prehnite, epidote, chlorite, and actinolitic amphibole, all of which are much more pervasive and abundant in the north than they are in the Ibra area.

6. It is important to note that all of these along-strike differences in ${ }^{18} \mathrm{O} /{ }^{16} \mathrm{O}$ systematics in the ophiolite were probably produced over a very narrow interval of time, at or very soon after initial formation of the oceanic crust at a spreading axis ( $-94-97 \mathrm{Ma}$, based on zircon ages from plagiogranites collected along the entire length of the ophiolite [Tilton et al., 1981]). This in tum suggests that when we are finally able to directly sample the three-dimensional ${ }^{18} \mathrm{O} /{ }^{16} \mathrm{O}$ systematics, structure, and stratigraphy in true oceanic crust formed at a mid-ocean ridge, we will probably observe analogous differences both along strike and with depth.

Acknowledgments. We wish to thank J. D. Smewing, T. Alabaster, A.W. Shelton, RT. Gregory, CA. Hopson, RG. Coleman, D. Norton, T. Juteau, A. Nicolas, and the late I. Reuber, for their advice and generous assistance in the field in Oman, as well as for numerous discussions about the nature of ophiolites and of the oceanic crust. Financial support for this research, including the field work and sampling in 1981, 1983, and 1985 , and the subsequent laboratory studies at Caltech and the University of South Carolina were provided by a series of NSF grants OCE-80. 19021, EAR-78-16874, EAR-83-13106, and EAR-88-16413. Much of the field work was carried out under the auspices of the Ministry of Petroleum and Mincrals, Oman, with logistical support from the Open 
University and the Oman Mining Company. Contribution No. 4912, Division of Geological and Planetary Sciences, California Institute of Technology, Pasadena, California 91125

\section{REFERENCES}

Alabaster, T., The interrelationship between volcanic and hydrothermal processes in the Oman Ophiolite, Ph.d. thesis, 290 pp., The Open Univ., Milton Keynes, England, 1982.

Alabaster, T., and J.A. Pearce, The interrelationship between magmatic and ore-forming hydrothermal processes in the Oman Ophiolite, Econ. Geol, 80, 1-16, 1985.

Alabaster, T., J.A. Pearce, and J. Malpas, The volcanic stratigraphy and petrogenesis of the Oman ophiolite complex, Contrib. Mineral. PetroL, $81,168-183,1982$.

Barnes, I., J.R. O'Neil, and JJ. Trecases, Present day serpentinization in New Caledonia, Oman and Yugoslavia, Geochim. Camochim. Acta, 42, 144-145, 1978.

Batiza, R., and S.H. Margolis, A model for the origin of small non-overlapping offsets (SNOOSs) of the East Pacific Rise, Nature, 320,439-441, 1986.

Batiza, $R$, and D. Vanko, Volcanic development of small oceanic central volcanoes on the flanks of the East Pacific Rise inferred from narrowbeam echo-sounder surveys, Mar. Geol, 54, 53-90, 1983.

Beurrier, M., The ophiolites of the central Oman mountains: An example of a propagating rift into former oceanic crust, paper presented at Symposium on Ophiolite Genesis and Evolution of Oceanic Lithosphere, UNESCO and Ministry of Petroleum and Minerals, Muscat, Oman, Jan. 1990.

Bird, D.K, and H.C. Helgeson, Chemical interaction of aqueous solutions with epidote-feldspar mineral assemblages in geologic systems, II, Equilibrium constraints in metamorphic/geothermal processes, $A$ m J. Sci, 281, 576-614, 1981.

Bird, D.K, R.D. Rogers, and C.E. Manning, Mineralized fracture systems of the Skaergaard intrusion, East Greenland, Medd Groenl Geasci, 16, 68 pp., 1986.

Boudier, F., and RG. Coleman, Cross-section through the peridotites in the Samail Ophiolite, southeastem Oman, J. Geophys. Rex, 86, 2573-2592, 1981.

Boudier, F., and A. Nicolas (Bds.), The ophiolites of Oman, Tectonophysics, 151, 1-401, 1988.

Boudier, F., J.L. Bouchez, A. Nicolas, M. Cannat, G. Ceuleneer, M. Misseri, and R. Montigny, Kinematics of oceanic thrusting in the Oman Ophiolite: Model of plate convergence, Earth Planet SCi. Lett, 37, 369-379, 1985.

Browning, $\mathbf{P}$., Cryptic variation within the cumulate sequence of the Oman Ophiolite: Magma chamber depth and petrological implications, Geol. Soc. Spec. Publ. London, 13, 71-82, 1984.

Cameron, W.E., Petrology and origin of primitive lavas from the Troodos ophiolite, Cyprus, Conurib. Mineral. Petrol, 89, 239-255, 1985.

Cannat, M., C. Mevel, and D. Stakes, Stretching of the deep crust at the slow spreading Southwest Indian Ridge, Tectonophysics, 190, 73-94, 1991.

Coish, R.A., and W.R. Church, Igneous geochemistry of mafic rocks in the Betts Cove ophiolite, Newfoundland, Contuib. Mineral Petrol, 70 , 29.39, 1979.

Coish, RA, R. Hickey, and P. Frey, Rare earth element geochemistry of the Betts Cove ophiolite, Newfoundland, complexities in ophiolite formation, Geochim. Cosmachim. Acta, 46, 2117-2134, 1983.

Coleman, RG., Tectonic setting for ophiolite obduction in Oman, $J$. Geophys. Res., 86, 2497-2508, 1981.

Coleman R, and C.A. Hopson (Eds.) The Samail Ophiolite, Oman, Special Issue, J. Geophys. Res., 86, 2495-2782, 1981.

Cooper, P.A., P.D. Milholland, and F.K. Duennebier, Seismicity of the Galapagos $95.5^{\circ} \mathrm{W}$ propagating rift,J. Geophys. Res., 92, 14,091-14,112, 1987.

Criss, R.E., and H.P. Taylor, Jr., Meteoric-hydrothermal systems, in Stable Isotopes in High-Temperature Geological Processes, edited by J.W. Valley, H.P. Taylor, Jr., and J.R. O'Neil, Mineral Soc. Am. Rev. Mineral, 16, 373-424, 1986.

Ernewein, M., C. Pflumio, and H. Whitechurch, The death of an accretion zone as evidenced by the magmatic history of the Sumail Ophiolite (Oman), Tectonophysics, 151, 247-274, 1988.

Feng, X., and S.M. Savin, Oxygen isotope studies of zeolites: stilbite, analcime, heulandite, and clinoptilolite, I, Analytical technique, in Stable Isotope Geochemistry: A Tribute to Samuel Epstein,edited by H.P. Taylor Jr., J.R O'Neil, and I. R. Kaplan, Spec. Publ Geochem. Soc., 3, 271-284, 1991.
Garlick, G.D., I.D. MacGregor, and D.E. Vogel, Oxygen isotope ratios in eclogites from kimberlites, Science, 172, 1025-1027, 1971.

Ghent, E.D., and M.Z. Stout, Metamorphism at the base of the Samail Ophiolite, southeastern Oman mountains, J. Geophys. Rex., 86, 2557. $2572,1981$.

Glennie, K.W., M.G.A. Boeuf, M.W. Hughs-Clarke, M. Moody- Stuart, W.F.H. Pilaar, and B.M. Reinhardt, Geology of the Oman Mountains, Part One (text), Part Two (tables and illustrations), Part Three (enclosures). Verh. K Ned Geol Mybouwkd, Genoot., 31, 423 pp., 1974.

Gregory, RT., Oxygen isotope history of seawater revisited: 3.5 billion years of the greenstone recond and its implications for the stability of seawater ${ }^{18} \mathbf{O}$, in Stable Isotope Geochemistry: A Tribute to Samuel Epstein, edited by H.P. Taylor Jr., J.R. O'Neil, and I. R Kaplan, Spec. Publ.Geochem. Soc, 3, 65-76, 1991.

Gregory, RT., and H.P. Taylor Jr., An oxygen isotope profile in a section of Cretaceous oceanic crust, Samail Ophiolite, Oman: Evidence for $\delta^{18}$ O buffering of the oceans by deep $(>5 \mathrm{~km}$ ) seawater-hydrothermal circulation at mid-ocean ridges, J. Geophys. Res, 86, 2737.2755, 1981.

Gregory, R.T., RE. Criss, and H.P. Taylor, Jr., Oxygen isotope exchange kinetics of mineral pairs in closed and open systems: Applications to problems of hydrothermal alteration of igneous rocks and Precambrian iron formations, Chem. Geol, 75, 1-42, 1989.

Harper, G.D., J.R. Bowman, and R. Kuhns, Field, chemical, and isotopic aspects of submarine hydrothermal metamorphism of the Josephine ophiolite, Klamath Mountains, California-Oregon,J. Geophys. Res., 93, $4625-4657,1988$.

Hawkins, J.W. and J.T. Melchior, Petrology of Mariana Trough and Lau Basin basalts, J. Geophys. Rec, 90, 11,431-11,468, 1985.

Hawkins, J.W., S.H. Bloomer, C.A. Evans, and J.T. Melchior, Evolution of intra-oceanic arc-trench systems, Tectonophysics, 102, 175-205, 1984.

Hopson, C.A., RG. Coleman, R.T. Gregory, J.S. Pallister, and E.H. Bailey, Geologic section through the Samail Ophiolite and associated rocks along a Muscat-Ibra transect, southestern Oman mountains, $J$. Geophys. Res, 86, 2527-2544, 1981.

Jahns, RH., and C.W. Bumham, Experimental studies of pegmatite genesis, I, A model for the derivation and crystallization of granitic pegmatites, Econ Geol, 64, 843-864, 1969.

Juteau, T., M. Beurrier, R. Dahl, and P. Nehlig. Segmentation at a fossil spreading axis: The plutonic sequence of the Wadi Haymiliyah area (Haylayn Block, Sumail Nappe, Oman), Tectonophysics, 151, 167-197, $1988 b$.

Juteau, T., M. Emewein, I. Reuber, H. Whitechurch, and R. Dahl, Duality of magmatism in the plutonic sequence of the Sumail Nappe, Oman, Tectonophysics, 151, 107-135, 1988 .

Karson, J.A., and P.A. Rona, Block-tilting, transfer faults and structural control of magmatic and hydrothermal processes in the TAG area, $26^{\circ} \mathrm{N}$, Geol. Soc. Am. Bull., 102, 1635-1645, 1990.

Kyser, T.K. Stable isotope variations in the mantle, in Stable lsotopes in High-Temperature Geological Processes, edited by J.W. Valley, H.P. Taylor, Jr., and J.R. O'Neil, Mineral. Soc. Am. Rev. Mineral, 16, 141-164, 1986.

Lanphere, M.A., K-Ar ages of metamorphic rocks at the base of the Samail ophiolite, Oman, J. Geophys. Res., 86, 2777-2782, 1981.

Liou, J.G., S. Kuniyoshi, and K Ito, Experimental studies of the phase relations between greenschist and amphibolite in a basaltic system, $A m$ J. Sci, 274, 613-632, 1974.

Liou, J.G., H.S. Kim, and S. Maruyama, Prehnite-epidote equilibria and their petrologic applications, J. Petrol, 24, 321-342, 1983.

Lippard, SJ., A.W. Shelton, and I.G. Gass, The Ophiolite of Northern Oman, Mem. Geol Soc. London, 11, 178 pp., 1986.

Macdonald, K.C., J.C. Sempere, and P.J. Fox, East Pacific Rise from Siqueiros to Orozco fracture zones: Along-strike continuity of axial neovolcanic zones and structure and evolution of overlapping spreading centers, J. Geophys. Res, 89, 6049-6069, 1984.

Macdonald, K.C., PJ. Fox, LJ. Perram, M.F. Eisen, R.M. Haymon, S.P. Miller, S.M. Carbotte, M.H. Cormier, and A.N. Shor, A new view of the mid-ocean ridge from the behaviour of ridge-axis discontinuities, Nature, 335, 217-225, 1988.

Manning, C.E, and D.K. Bird, Hydrothermal clinopyroxenes of the Skaergaard intrusion, Contrib. Mineral. Petrol, 92, 437-447, 1986.

Maruyama, S., K. Suzuki, and J.G. Liou, Greenschist-amphibolite transition equilibria at low pressure, J. Petrol, 24, 583-604, 1983.

Muehlenbachs, K and R.N. Clayton, Oxygen isotopic composition of the oceanic crust and its bearing on seawater, J. Geophys. Res., 81,4365 4369, 1976.

Nehlig, P., and T.Juteau, Flow porosities, permeabilities and preliminary 
data on fluid inclusions and fossil thermal gradients in the crusta sequence of the Sumail Ophiolite, Oman, Tectonophysics, 151, 199-221, 1988.

Nicolas, A., G. Ceuleneer, F. Boudier, and M. Misseri, Structural mapping in the Oman Ophiolites: Mantle diapirism along an oceanic ridge, Tectonophysics, 151, 27-55, 1988 a.

Nicolas, A., F., I. Reuber, and K. Benn, A new magma chamber model based on structural studies in the Oman Ophiolite, Tectonophysics, 151, 87-105, $1988 b$.

Norton, D., and H.P. Taylor, Jr., Quantitative simulation of the hydrothermal systems crystallizing magmas on the basis of transport theory and oxygen isotope data: An analysis of the Skaergaard intrusion, J. Petrol, 20, 421-486, 1979.

O'Neil, J.R, and H.P.Taylor, Jr., The oxygen isotope and cation exchange chemistry of feldspars, Am. Mineral, 52, 1414-1437, 1967.

Pallister, J.S., and C.A. Hopson, Samail Ophiolite plutonic suite: Field relations, phase variation, cryptic variation and layering, and a model of a spreading ridge magma chamber, J. Geophys. Res, 86, 2593-2644, 1981.

Papike, JJ., KL. Cameron, and K. Baldwin, Amphiboles and pyroxenes: Characterization of other than quadrilateral components and estimates of ferric iron from microprobe data (abstract), Geol Soc. Am. Abstr. Progams, 6, 1053-1054, 1974.

Pearce, J.A., T. Alabaster, A.W. Shelton, and M.P. Searle, The Oman Ophiolite as a Cretaceous arc-basin complex. Evidence and implications, Philas Trans. $R$ Soc. London, Ser. A, 300, 299-317, 1981.

Pflumio, $C$., Histoire magmatique et hydrothermale du bloc de Salahi: Implications sur l'origine et l'evolution de l'ophiolite de Semai (Oman), doctoral dissertation, 243 pp., Ecoles des Mines de Paris, 1988.

Reuber, 1., Complexity of the crustal sequence in the northem Oman Ophiolite (Fizh and southem Aswad blocks): The effect of earty slicing?, Tectonophysics, 151, 137-165, 1988.

Reuber, I., P. Nehlig, and T. Juteau, Axial segmentation, off-axis mantle diaprirism and hydrothermal circulation in the Heylayn block, Semai Ophiolite, paper presented at Symposium on Ophiolite Genesis and Evolution of Oceanic Lithosphere, UNESCO and the Ministy of Petroleum and Minterals, Muscat, Oman, Jan. 1990.

Robinson, P., F.S.Spear, J.C.Schumacher, J. Laird, C. KJein, B.W. Evans, and B.L. Doolan, Phase relations of metamorphic amphiboles: Natural occurrence and theory, in Amphiboles: Petrology and Experimental Phase Relations, edited by D.R. Veblen and P.H. Ribbe, Mineral Soc. Am. Rev. Mineral, 9B, 1-227, 1982.

Schiffman, P., and B.M. Smith, Petrology and oxygen-isotope geochemistry of a fossil seawater hydrothermal system within the Solea graben, northern Troodos Ophiolite, Cyprus, J. Geophys. Res, 93, 4612-4624, 1988.

Sempre, J.-C., and K.C. Macdonald, Deep-tow studies of the overlapping spreading centers at $9^{\circ} 03^{\prime} \mathrm{N}$ on the Bast Pacific Rise, Tectonics, 5, 881-900, 1986.

Smewing, J.D., An Upper Cretaceous ridge-transform intersection in the Oman Ophiolite in Ophiolites, Proceedings, International Ophiolite Symposium, Cyprus, 1979, pp. 407-413, Cyprus Geological Survey, Nicosia, 1980.

Smewing, J.D., Mixing characteristics and compositional differences in mantle-derived melts beneath spreading axes: Evidence from cyclically layered rocks in the ophiolite of North Oman, J. Geophys. Res., 86, 2645-2659, 1981.

Smewing, J.D., N.I. Christensen, I.D. Bartholomew, and P. Browning The structure of the oceanic upper mantle and lower crust as deduced from the northern section of the Oman Ophiolite, in Ophiolites and Oceanic Lithosphere, edited by I.G. Gass, SJ. Lippard, and A.W. Shelton, Geol Soc. Spec. Publ London, 14, 41-54, 1984.

Smewing, J. D., Field Guide to Excursion E4: Sections through the Northern Ophiolite: Wadi Rajmi and Wadi Fizh, Symposium on Ophiolite Genesis and Evolution of Oceanic Lithosphere, Minist. of Petr. and Miner., Sultanate of Oman, Muscat, Jan. 1990.

Spear, F.S., NaSi = CaAl exchange equilibrium between plagioclase and amphibole: An empirical model, Contrib. Mineral Petrol, 72, 33-41, 1980.

Stakes, D.S., J.W. Shervais, and C.S. Hopson, The volcanotectonic cycle of the FAMOUS and AMAR valleys, Mid-Atlantic Ridge (36 $47 \mathrm{~N}$ ): Evidence from basalt and phenocryst compositional variation, $J$. Geophys. Res, 39, 6995-7028, $1984 a$.

Stakes, D., C. Mevel, M. Cannat, and T. Chaput, Metamorphic history of ODP site 735B, Southwest Indian Ridge, Proc. Ocean Drill. Program, $118,153-180,1991$.

Stakes, D.S., H.P. Taylor, and R.L. Fisher, Oxygen-isotope and geochemical characterization of hydrothermal alteration in ophiolite complexes and modern oceanic crust, in Ophiolites and Oceanic Lithosphere, edited by I.G. Gass, S.J. Lippard, and A.W. Shelton, Geol Soc. Spec. Publ London, 14, 199-214, 1984b.

Taylor, H.P., Jr., The oxygen isotope geochemistry of igneous rocks, Contrib. Mineral Petrol, 19, 1-71, 1968.

Taylor, H.P., Jr., The application of oxygen and hydrogen isotope studies to problems of hydrothermal alteration and ore deposition, Econ. Geol, 69, 843-883, 1974.

Taylor, H.P., Jr., Water-rock interactions and the origin of $\mathrm{H}_{2} \mathrm{O}$ in granitic batholiths, J. Geol. Soc. London, 133, 509-558, 1977.

Taylor, H.P., Jr., Igneous rocks, II, Isotopic case studies of circumpacific magmatism, in Stable Isotopes in High-Temperature Geological Processes, edited by J.W. Valley, H.P. Taylor, Jr., and J.R. O'Neil, Mineral Soc. Am. Rev. Mineral, 16, 273-317, 1986.

Taylor, H.P., Jr., and R.W. Forester, An axygen and hydrogen isotope study of the Skaergaard intrusion and its country rocks: A description of a 55-m.y. old fossil hydrothermal system, J. Petroh, 20, 335-419, 1979.

Taylor, H.P., Jr., and S.M.F. Sheppard, Igneous rocks, I, Processes of isotopic fractionation and isotope systematics, in Stable Isotopes in High-Temperature Geological Processes, edited by J.W. Valley, H.P. Taylor, Jr., and J.R O'Neil, Mineral Soc. Am. Rev. Mineral., 16, 227. $271,1986$.

Tilton, G.R, C.A. Hopson, and J.E. Wright, Uranium-lead isotopic ages of the Samail ophiolite, Oman, with applications to Tethyan Ocean ridge tectonics, J. Geophys. Res, 86, 2763-2776, 1981.

Tivey, M.A., H. Schouten, J. Lin, J.C. Sempre, and A. Woolridge, Predictions of hydrothermal fields on the Mid-Atlantic Ridge based on magnetic anomalies (abstract), Eos Trans. $A G U, 70,1325,1989$.

Vanko, D.A., and D. S. Stakes, Fuids in oceanic layer 3: evidence from veined rocks, hole $735 B$, Southwest Indian Ridge, Proc. Ocean Drill Program, 118, 181-215, 1991.

Varga, RJ., and E.M. Moores, Spreading structure of the Troodos ophiolite, Cyprus, Geology, 13, 846-850, 1985.

Vetter, S., and D. Stakes, The northern Semail plutonic suite: Field and trace element evidence for repeated magma injection in the construction of back-arc crust, in Troodos 87 Ophiolites and Oceanic Crust, Special Volume, Cyprus Geological Survey, Nicosia, 397-412, 1990.

Vogel, D.E, and G.D. Garlick, Oxygen isotope ratios in metamorphic eclogites, Contrib. Mineral Petrol, 28, 183-191, 1970.

Wickham, S.M., and H.P. Taylor, Jr., Stable isotope evidence for largescale seawater infiltration in a regional metamorphic terrane: The Trois Seigneurs massif, Pyrenees, France, Contrib. Mineral Petrol, 91, 122$137,1985$.

Wickham, S.M. and H.P. Taylor, Jr., Stable isotope constraints on the origin and depth of penetration of hydrothermal fluid associated with Hercynian low-pressure regional metamorphism and crustal anatexis in the Pyrenees, Contrib. Mineral Petrol, 95, 255-269, 1987.

D. S. Stakes, Department of Geology, University of South Carolina, Columbia, SC 29208.

H.P.Taylor, Jr., Division of Geological and Planetary Sciences, California Institute of Technology, Pasadena, CA 91125.

(Received February 22, 1991: revised October 28, 1991; accepted October 28,1991 .) 